UNIVERSIDADE DE SĀO PAULO

INSTITUTO DE GEOCIEENCIAS

DEDALUS - Acervo - IGC

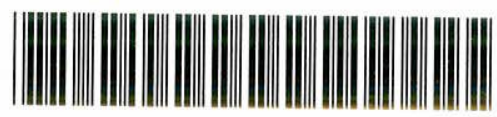

30900004914

VEGETAIS FÓSSEIS DA FORMAÇÃO ITAQUAQUECETUBA (CENOZÓICO, BACIA DE SÃO PAULO)

Fernando Cilento Fittipaldi

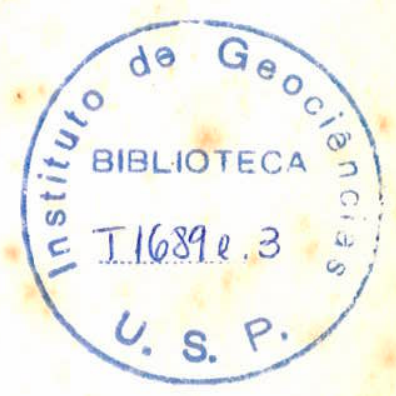

Orientador: Prof. Dr. Oscar Rösler

TESE DE DOUTORAMENTO

\title{
COMISSÃO EXAMINADORA
}

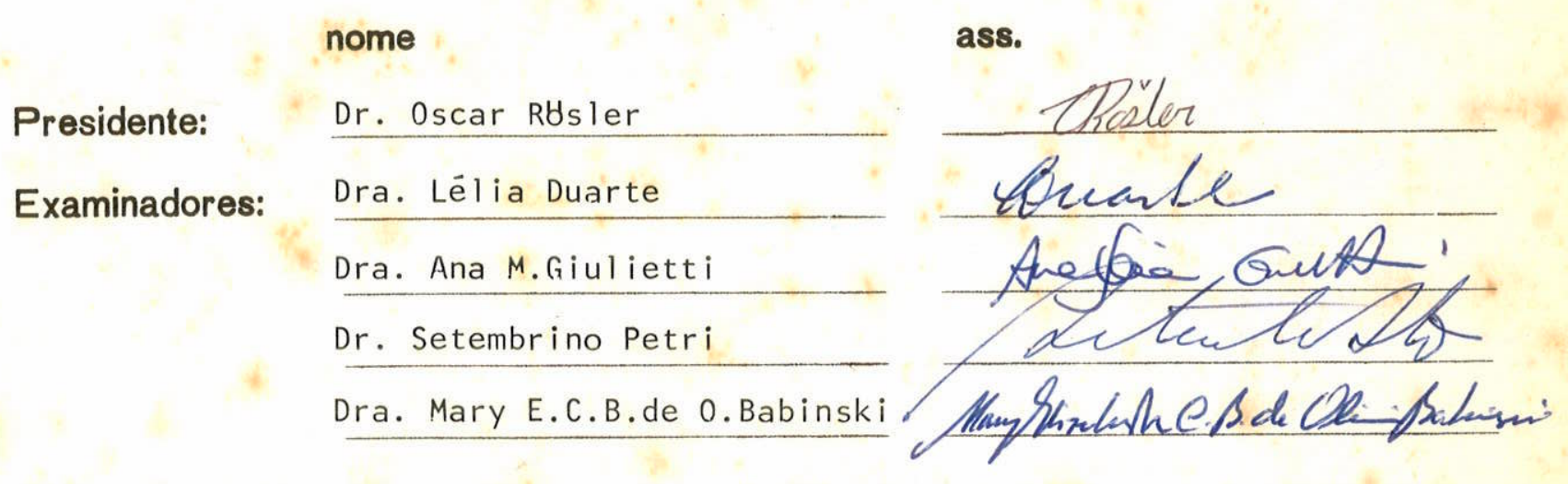

São Paulo

1990 


\section{INAIIIICER}

RESUMO

vi.

ABSTRACT

\section{CAPITULO 1}

INN"IRODUÇÃO

1.1. AGRADECIMENTOS -

1.2. LOCALIZAÇÃO DA ÅREA DE ESTUDO

1.3. CONTEXTO GEOLరGGICO REGIONAL _-

1.3.1. BACIA DE SÃO PAULO

1.3.2. FORMAÇÃO ITAQUAQUECETUBA -...- 7

\section{CAAPIIIUILO 2}

MA'TERIAL E METODOS

2.1. MATERIAL

2.2. METODOS DE COLETA E ESTUDO'

2.3. CRITÉRIOS PARA A ATRIBUIÇÃO GENERICA

CAPPIIIULOO 3

\section{SIS I"IEMMÁTICA}

3.1. BRIOFITAS

3.2. PTERIDÓFITAS

3.3. ANGIOSPERMAS

3.3.1. FOLHAS

3.3.2. SEMENTES

3.3.3. FRUTOS

3.3.4. FRUTOS

(?) 


\section{CAPÍTULO 4}

COMPARAÇÃO COM RESTOS VEGETAIS ASSINALADOS EM OUTROS DEPOSI TOS CENOZOICOS DO ESTADO DE SÃO PAULO - 74

4.1. BACIA DE TAUBATE

4.1.1. FORMAÇÃO TREMEMBÉ - 76

4.1.2. SEDIMENTOS SOBREJACENTES A FORMAÇÃO TREMEMBE--- 78

4.2. FORMAÇÃO RIO CLARO - 81

4.3. FORMAÇÃO PARIQUERA-AÇU - 82

4.4. FORMAÇÃO CANANEIA

4.5. DEPరুSITOS ISOLADOS

4.5.1. TANQUE - 85

4.5.2. JAZIGO VARGEM GRANDE DO SUL

4.5.3. DEPÓSITOS DE VÁRZEAS DO PARATEİ-_..- 88

\section{CAPITULO 5}

PALEOCLIMA

5.1. PALEOCLIMA DA FORMAÇÃO ITAQUAQUECETUBA - 90

5.1.1. ZONAÇÃO ALTITUDINAL _- 91

5.2. INFERÊNCIAS PALEOCLIMÃTICAS _-

5.3. INDICADORES PALEOCLIMÁTICOS _- 98

5.3.1. ARQUITETURA FOLIAR - 98

5.3.1.1. Tamanho _- 100

5.3.1.2. Tipo de Margem - 102

5.3.1.3. Tipo de ápice

5:3.1.4. Textura

5.3.2. NUMERO DE ESPÉCIES - 
5.4. DISTRIBUIÇÃO GEOGRÃFICA ATUAL DOS GENEROS ASSINALADOS NA TAFOFLORA DA FORMAÇÃO ITAQUAQUECETUBA

5.5. RESULTADOS 115

5.6. COMENTARIOS

115

5.7. DISCUSSÃO

CANIIILO 6 


\section{INDICE DAS FIGURAS}

Figura 1 - Esboço geológico dos portos de areia de Itaquaquecetuba, com a localização aproximada dos

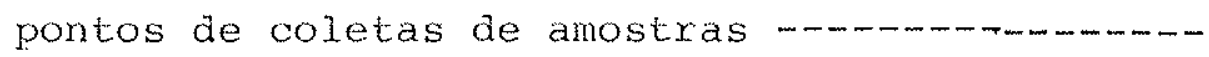

Figura 2 - Mapa geológico regional com as áreas de exposi-

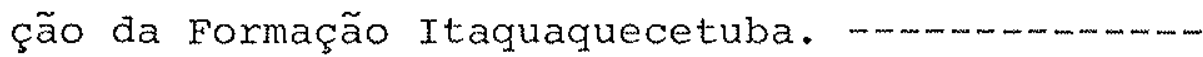

Figura 3 - Megaclasto de dimensões métricas, areno-argiloso, de coloração chocolate, rico em matéria orgânica. Inclui folhas, fragmentos de caules e estruturas reprodutivas.

Figura 4 - Vista geral do porto de areia no 1 da Itaqua -

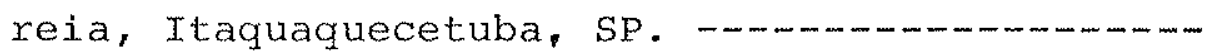

Figura 5 - Camada de espessura centimétrica de concentra ção de grãos e grânulos oriundos da cominuição dos megaclastos ricos em restos vegetais, inter calada em arenitos fluviais de granulação grossa a média.

Figura 6 - ordens de nervação.

Figura 7 - Principais ocorrências de sedimentos cenozóicos no estado de são paulo e suas relações com as grandes feições tectônicas. 


\section{R E S U M O}

Os nĩveis fossilifferos da Formação Itaquaquecetuba (Cenozóico, Bacia de são Paulo), intexpretados como:! megaclastos de origem tectônica, são muito xicos em restos regetais que, embo ra incluam alguns dos elementos mais notáveis de documentário paleontológico da Bacia de são Paulo, ainda eram relativamente pouco conhecidos. Esses restos são representados principalmente por compressões foliares e por provāveis estruturas reprodutivas car bonificadas. Algumas folhas, em função da textura fina da matriz, exibem alto grau de detalhe da nervação.

Os principais objetivos do presente trabalho são: a) estabelecer, através da determinação e descrição, a taxonomia dos restos vegetais, especialmente folhas, da área-tipo daquela $\underline{\text { u}}$ nidade, no município de Itaquaquecetuba, SP; b) determinar o pos sível significado paleoclimático da tafoflora, com base nos análo gos modernos, e, consequentemente, discutir os problemas ligados ao ambiente deposicional dos níveis que contém esses restos; fornecer subsidios para o estabelecimento de eventuais correlações com restos vegetais assinalados em outros depósitos cenozóicos brasileiros.

Dentre as formas conhecidas anteriormente para esta localidade, foram revisadas: Luehea divaricatiformis, Schizolobium inaequilaterum, Myroia cf. rostrataformis, Psidium pau lense, Byrsonima butzata, Serjania itaquaquecetubensis e serjania lancifolia. Alēm destas, são propostas oito novas espëcies de 
angiospermaslocotea pulchelliformis, Piptadenia tertiaria, Cassia rosleri, Sophora giuliettiae, Machaerium piranii, Bertolonia coim brai, Tocoyena riccominii e Echinodorus rossiae), uma de pteridófita (Lindsaea pradoi)e uma de briófita (Isotachis simonesi).

A tafoflora estudada é sugestiva de uma mata tropi cal úmida (mata pluvial), visto que as formas identificadas apresentam equivalentes atuais que ocupam este tipo de ambiente. Tais formas apresentam pequena utilidade em correlações temporais desde que, devido à sua grande distribuição ao longo do cenozóico , não são diagnósticas do ponto de vista cronológico. As informa ções paleoambientais fornecidas pelos vegetais seriam tambēm váli das para a região onde os blocos se depositaram, apenas no caso destes serem penecontemporâneos à sedimentação. 
At its type locality the Itaquaquecetuba Formation (Cenozoic, São Paulo Basin) exhibits argillaceous megaclasts - of possible tectonic origin - included in coarser sediments. These megaclasts are rich in plant body fossils and show some of the most remarkable leaf compressions and coalified reproductive struc tures known in the são paulo Basin. Palynomorphs suggest an Oligocene age for this material. Thus, the Itaquaquecetuba : compression flora is especially important for better understanding the Cenozoic floral evolution of southeast Brazil. Despite the importance of this flora, only one taxonomic study has been under taken previously.

The main objectives of the present study are:

detailed taxonomic description of the preserved leaves; b) envi rommental interpretation of the ancient flora based on comparison with apparent modern counterparts; c) comparison with other Bra zilian Cenozoic fossil plant occurences as a contribution to correlation studies.

The following previously described taxa are here revised: Luehea divaricatiformis, Schizolobium inaequilaterum, Myrcia cf. rostrataformis, Psidium paulense, Byrsonima bulzata, Serjania itaquaquecetubensis e Serjania lancifolia.

Eight new species of angiosperms are here propo sed: Ocotea pulchelliformis, piptadenia tertiaria, Cassia roste- 
ri, Sophora giuliettiae, Machaerium piranii, Bertolonia coimbrai, Tocoyena riccominit and Echinodorus rossiae). One new species of Pteridophyta (Lindsaea pradoi) and one of Bryophyta (Isotachis simonesi) are also proposed.

Chronologic correlation between this flora and the other Brazilian Cenozoic floras is not yet possible, partly due to the present level of taxonomic knowledge of the other floras.

From an evironmental point of view, this assemblage is strongly suggestive of a tropical rain forest at the time of deposition of the argillaceous sediments. Such a conclusion would be valid for the Itaquaquecetuba Formation as a whole only if the interval between original deposition and subsequent reworking of the fossiliferous clayey material were very short. 


\section{INTRODUÇÃO}

Apesar dos avanços da Paleobotânica ao longo das ültimas décadas, a flora cenozóica do Brasil ainda é relativamente pouco conhecida, principalmente devido à distribuição, até o presente, pontual, de restos vegetais bem preservados. No território paulista, em especial, o documentärio paleobotânico dos depósitos cenozóicos tem merecido pouca atenção por parte dos pes quisadores. Dentre estes depósitos, destaca-se, pela abuñânincia de restos identificáveis, a Formação Itaquaquecetuba.

Denominada anteriormente "aluviões antigos dos rios Tietê e Pinheiros", a Formação Itaquaquecetuba se constitui numa das duas unidades litoestratigráficas reconhecidas na ārea da Bacia de são paulo. Seu conteúdo fossilifero é composto basica mente por restos vegetais, em grande parte restritos a níveis orgânicos bastante discretos. Nestes, destacam-se abundantes folhas carbonificadas que, embora se constituam em alguns dos elementas mais notáveis do documentário paleontológico da Bacia de são Pau10, foram objeto, até o presente, apenas de um estudo preliminar.

As inferências paleoclimáticas obtidas a partir do estudo desses vegerais se revestem de especial importância por que, confrontadas com as sugeridas pelos processos e sistemas deposicionais admitidos para a Formação Itaquaquecetuba, podem for- 
necer importantes subsidios para a definição do paleoclima reinan te na época deposicional dos niveis fossiliferos daquela forma Ção o que, ainđa, é objeto de controvérsia.

Outrossim, um maior conhecimento a respeito desses vegetais pode propiciar o estabelecimento de eventuais correlações de suas camadas portadoras com depósitos de outras bacias tafrogê nicas do sudeste brasileiro, em especial da Bacia de Taubaté, que tem sido considerada sincrônica com a Bacia de são Paulo. Conse quentemente, pode também trazer subsídios para a definição da cronologia da Formação Itaquaquecetuba, bem como para o problema da distribuição geográfica das angiospermas durante o cenozóico.

Desta forma, os principais objetivos do ipresente estudo são: a) estabelecer, através da determinação e descrição, a taxonomia dos restos vegetais, especialmente folhas, da ārea-ti po da Formação Itaquaquecetuba; b) determinar o possível significado paleoclimático da tafoflora, com base nos análogos moder nos, e, consequentemente, discutir os problemas ligados ao ambien te deposicional dos niveis que contém esses restos; c) fornecer subsidios para o estabelecimento de eventuais correlações com res tos vegetais assinalados em outros depósitos cenozóicos brasileiros. 


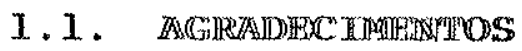

O autor deseja expressar seu profundo reconhecimen to a todas as pessoas ou entidades que, de uma forma ou de outra, colaboraram para a realização deste trabalho.

Ao Professor Oscar Roslex pela orientação e acompa nhamento durante todo o desenvolvimento do trabalho.

Ao Professor Marcello Guimarães Simões pelas crîti cas e sugestões apresentadas, bem como pelo auxỉio prestado em todas as etapas da preparação deste trabalho, em especial no que se refere a trabalhos de campo e à montagem de estampas.

Aos Professores Armando Marcio Coimbra e Clāudio Riccomini pelo estímulo constante, pelas sugestões e discussões a presentadas, pela cessão de bibliografia e pelo apoio em trabalhos de campo.

Aos Professores Ana Maria Giulietti e Josē Rubens Pirani pelo grande auxilio prestado na identificação dos fósseis, pelas sugestões e discussões apresentadas, pelo empréstimo de bibliografia, e por terem facilitado o acesso ao laboratório de sis temática e ao Herbārio do Departamento de Botânica do instututo de Biociências da usp.

A Jefferson Prado pela ajuda na identificação das pteridófitas e na utilização de equipamento fotográfico. 
A Lucia Rossi, Olga Yano, Silvia Antonia Correa Chieda, Elisabete A.Lopes, Eduardo Luis Martins Catharino e Haroldo Caval cante de Lima pelo auxílio na identificação de diversas formas.

A Professora Mary E.C.B. de Oliveira-Babinski pelas criticas e sugestões apresentadas com base na paciente leitura dos originais deste trabalho.

Ao Professor Thomas Rich Fairchild pela revisão do "abstract".

A Professora Jane E. Kraus pela orientação na diafani zação de material recente e no estudo de galhas.

A Gilmar E.Valente e Marco Antonio do Rego pelo auxi lio na diafanização de material recente.

A Antero Saraiva por ter possibilitado a execução de trabalhos de campo nos portos de areia da Itaquareia.

A Itacy Kroehne pela confecção de figuras e pelas sü gestões a respeito da montagem de estampas.

A Jaime de Souza Marcos pela preparação das :fotos utilizadas para a montagem de estampas.

Aos funcionários do Instituto de Geociências da USP, em especial à Maria Lucia Belisārio Cicconi, Luzia Sonia Candeo e Jayme Alves da Silva, pelo auxílio prestado em diversas ocasiões.

\section{A CAPES pelo apoio financeiro.}

Ao Departamento de Palentontologia e Estratigrafia por ter propiciado a utilização de suas instalações e laborató rios para a realização do presente trabalho. 


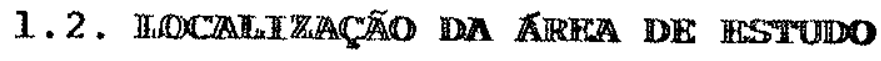

O material fóssil aqui estudado é proveniente de uma cava de extração de areia, de propriedade da Itaquareia S.A., situada na margem direita do Rio Tietê, no municipio de Itaguaque cetuba, SP (figura 1). O acesso ao local, distante aproximadamen te $35 \mathrm{~km}$ a $\mathrm{NE}$ da cidade de são Paulo, pode ser feito através da Rodovia Presidente Dutra ou Rodovia dos Trabalhadores.

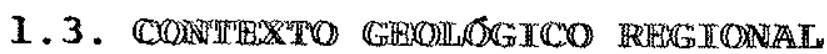

\subsubsection{HBATIIA DE SÃO PAULO}

A Bacia de são Paulo representa uma das principais depressões tectônicas de um sistema de bacias tafrogênicas continentais, de idade terciāria, denominado "Sistema de Rifts Conti nentais da Serra do Mar" (ALMEIDA, 1976), também integrado pelas bacias de Taubatē, Resende, Volta Redonda e Curitiba, bem como pelo Rift da Guanabara e pelo Gräben de Sete Barras. Elas : estão dispostas sobre uma faixa de orientação geral E-NE, paralela à linha de costa atual (MELO et al., 1985).

Embora existam algumas divergências quanto ao meca nismo de evolução e à cronologia dos eventos, admite-se que a ori gem do sistema è consequencia da abertura do Atlântico sul, em função dos fenômenos relacionados à reativação Wealdeniana ( MELo et al., 1986). A origem do sistema estaria ligada, portanto, à ruptura da porção crustal adjacente à Bacia de Santos, como conse quência da tensão imposta pelos movimentos verticais opostos - 


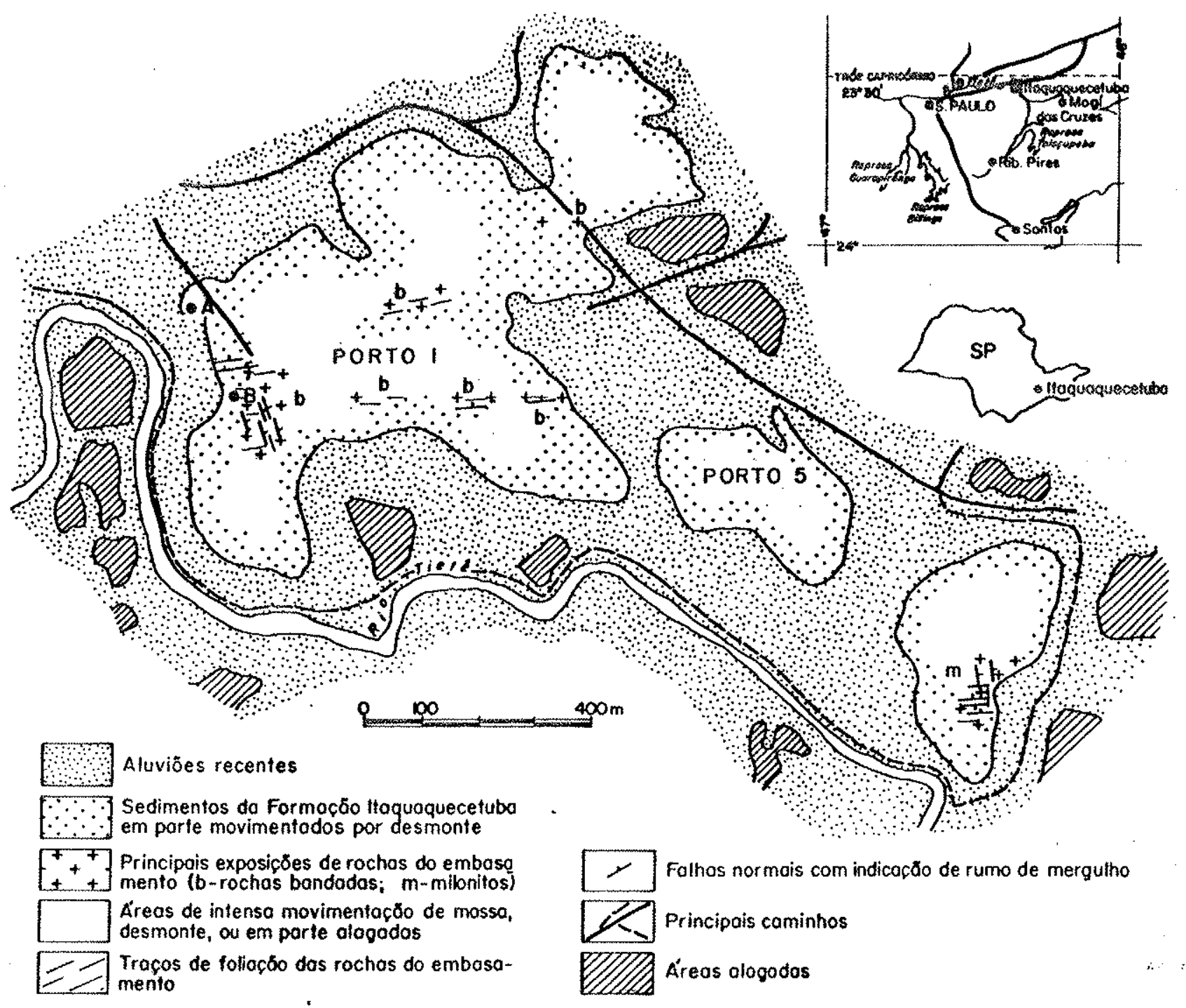

Figura 1 - Esboço geológico dos portos de areia de Itaquaquecetu ba, com a localização aproximada dos pontos de coletas de amos tras (modificado de COIMBRA et al., 1983). 
subsidência da bacia e soerguimento (por compensação isostática) da região costeira adjacente (ASMUS \& FERRARI, 1978, segundo RICCOMINI, 1989$)$.

MELO et al. (1985) concluem que as semelhanças do arcabouço estrutural, a similaridade das facies sedimentares en contradas, e o sincronismo observado, indicam que as várias bacias tiveram evolução homóloga, ligada aos mesmos processos de distensão regional.

A Bacia de São Paulo estä desenvolvida sobre terre nos cristalinos de idade brasiliana (Pan-Africana) e mais antiga, referíveis ao cinturão de dobramentos Ribeira (HAsUI et al. , 1975). A bacia é um hemi-gräben com basculamento para NNW, preen chido com até 290 metros de espessura de sedimentos (ALMEIDA, 1955).

São reconhecidas na āxea duas unidades litoestratị grāficas: a Formação São Paulo (PISSIS, 1842) e a Formação Itaqua quecetuba (COIMBRA et al., 1983).

\subsubsection{FOIRMAČÁO TINAQUAQUHCETUBA}

Os depósitos da Formação Itaquaquecetuba, cuja denominação formal foi proposta por CoIMBRA et al. (1983), foram es tudados inicialmente por JUNQUEIRA (1969) e subseqtentemente deno minados "aluviões antigos dos rios Tietê e Pinheiros" (Suguro \& TAKAHASHI, 1970; SUGUIO, 1971; SUGUIO et a1., 1971) e "camadas cruzadas da fase Butantã" (AB'SABER, 1978, 1980). Estes sedimen tos ocorrem principalmente sob as planícies atuais dos rios Tietê 
e Pinheiros (figura 2), atingindo na área de Itaquaquecetuba cerca de $40 \mathrm{~km}$ de comprimento, até $2 \mathrm{~km}$ de largura e espessura máxima da ordem de $50 \mathrm{~m}$ (COIMBRA et al., 1983). Alguns autores (ALMEI DA et al., 1984; VESPUCCI, 1984) sugeriram a extensão da unildade a áreas ocupadas pelas bacias de Taubaté, Resende e Volta Redonda. Tais afirmações, no entanto, carecem de evidências concretas, vis to que ainda restam dúvidas sobre a idade e posição estratigráfi ca da formação, o que prejudica tentativas de correlação baseadas apenas em características litológicas e de estruturas sedimenta res (ATENCIO, 1986).

No momento, esses sedimentos podem ser melhor ob servados no alto vale do Rio Tietê, em cavas abertas para a extra ção de areia na região de Itaquaquecetuba e Suzano. Outra boa exposição podia ser vista na margem esquerda do Rio Pinheiros, na área onde atualmente se situa a raia olímpica da Cidade Universitária, em cava estudada por TOLENTINO (1965), JUNQUEIRA (1969), SU GUIO \& TAKAHASHI (1970), SUGUIO (1971), SUGUIO et al. (1971) e BIGARELLA $(1971,1975)$. Em "portos de areia" atualmente entulhados ou alagados, situados à margem direita do Rio Pinheiros, entre as avenidas Nações Unidas e Pedroso de Morais (COIMBRA et al., 1983), bem como na região de Carapicuiba (SUGUIO \& TAKAHASHI, 1970), também podiam ser observadas exposições da unidade.

- Seus depósitos aparecem sempre em cotas relativa mente baixas, preenchendo antigos canais fluviais escavados diretamente sobre o substrato de rochas pré-cambrianas. Frequlentemente eles são capeados por aluviões recentes, pouco espessos, com descontinuidade erosiva basal, que indica fase erosiva generaliza 


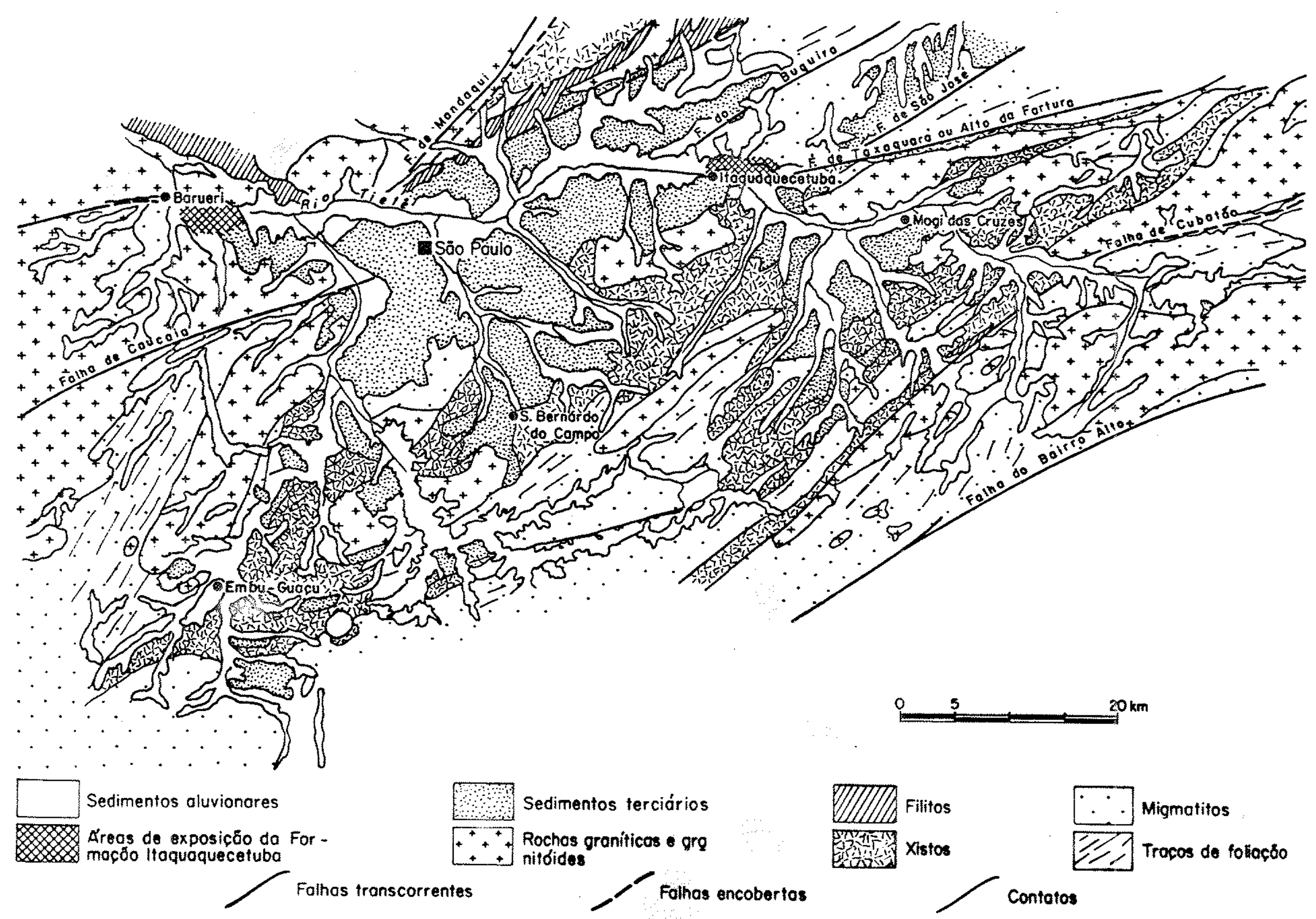

Figura 2 - Mapa geológico regional com as áreas de exposição da Formação Itaquaạuecetuba (BISTRICHI et al., 1981 , modificado por COIMBRA et al., 1983). 
da pōs-Itaquaquecetuba (ALMEIDA et al., 1984). A superfície erosi va está situada a cerca de $710 \mathrm{~m}$ de altitude, aproximadamente na possível interface entre essa unidade e a Formação são paulo, con trolada pela soleira de Barueri (ALMEIDA et al., 1984).

A idade da Formação Itaquaquecetuba tem sido objeto de grande controvérsia. Inicialmente ela foi atribuída ao Pleistoceno, com base nas relações de contato com a Formação são Paulo e o embasamento, e em datações radiométricas de troncos car bonificados, que sugexiram idades superiores a 40.000 anos (BIGARELLA, 1971; SUGUIO, 1971). Estudos paleomagnéticos constararam um evento de polaridade reversa, sugerindo uma idade minima de 730.000 anos (MELO et al., 1985). Resultados de estudos paltnológicos dos niveis fossiliferos, de outro lado, descartaram definitivamente a idade quaternāria, sugerindo idades compreendidas entre o Eoceno e o Oligoceno (MELO, 1984; MELO et al., 1985; MELO et al., 1986). No momento, parece plausível admitir uma idade oli gocênica para aqueles niveis, em função da presença de certos taxons estratigraficamente importantes para o Terciārio brasileiro, tais como Cicatricosisporites dorogensis, Margocolporites van wijhei, seiadopityspolzenites serratus, sciadopityspolzenites quintus, Perfotricolpites digitatus, Catinipoliis geiseltalensis, Psilastephanoporites stellatus, Magnaperiporites spinosus e Qua drapianus spl= Tetradites sp) (LIMA \& MELO, 1989).

Em consequência de uma erosão pronunciada, que removeu as transições, as relações entre os depōsitos atribuídos às formações São paulo e Itaquaquecetuba não são muito nîtidas, o que tem determinado linhas de intexpretação alternativas, ora con siderando-se a Formação Itaquaquecetuba como mais nova, ora consi 
derando as unidades como interligadas dentro de um novo sistema deposicional relativamente complexo, passando lateralmente de leques aluviais para planície e lago, e verticalmente observando-se reorganização do sistema fluvial, com passagem gradativa para con dições meandrantes (MELO et al., 1989).

A formação é constituída por "leques aluviais com conglomerados a blocos e matacões em matriz arenosa sem lama, associados a planfcie aluvial "braided" com barras longitudinais de cascalhos e areias grossas, e barras com cristas transversais pro vavelmente linguóides, com arenitos de dunas sub-aquosas" (MELO et al., 1989). Apresenta värias semelhanças com depósitos do tipo "roll", entre as quais a presença de uma porção sulfetada e ou tra oxidada (ATENCIO, 1986). A exposição atual da formação a ambi ente oxidante, pela abertura das cavas para a exploração de areia, leva à transformação intempérica dos sulfetos em sulfatos e goe thita (ATENCIO, op.cit.).

A unidade è formada predominantemente por areias grossas, mal selecionadas, com grãos angulosos a sub-arredonda dos e pouca matriz siltico-argilosa. O arcabouço é constituído de quartzo monocristalino e feldspatos (microclínio e plagioclásio), ocorrendo secundariamente grãos de quartzo policristalino (quartzitol e uma série de minerais pesados. O fato dos grãos dos minerais pesados se apresentarem angulosos demonstra condições de cur to transporte e proximidade da ärea-fonte, o que caracteriza uma derivação direta das rochas metamōrficas, e não o retrabalhamento de sedimentos prë-existentes (COIMBRA et al., 1983).

Os arenitos formam bancos de até $2 \mathrm{~m}$ de espessura 
e continuidade lateral de 10 a $20 \mathrm{~m}$, constituindo aproximadamente 808 do depósito (ATENCIO, 1986). Nestes sedimentos são comuns as estratificações cruzadas tabulares e tangenciais de médio porte, com mergulhos para $\mathrm{NW}$ e $\mathrm{SW}$ indicando paleocorrentes deposicionais provenientes de $\mathrm{E}$ (NE e SE), o que também é comprovado pelo estudo de orientação de seixos imbricados (COIMBRA et al., 1983).

De acordo com cormbra et al. (1983), além dos depó sitos arenosos, ocorrem dois tipos de níveis conglomeräticos. o primeiro, de forma lenticulax, com pequena espessura, caracteriza a base de paleocanais, incluindo seixos e blocos de siltito com dimensões de atē $30 \mathrm{~cm}$. Estes depósitos são formados basicamente por fragmentos de sedimentitos da própria bacia (intraclästicos) oriundos de escavações de pequenas lentes argilosas. Os corpos a renosos lenticulares que preenchem os paleocanais situados lacima desses conglomerados apresentam comumente estratificações cruza das acanaladas. O segundo tipo è composto por conglomerados "clast suported", que formam paleopavimentos detríticos de $10 \mathrm{~cm}$ a pouco mais de $1 \mathrm{~m}$ de espessura, com seixos de $10-20 \mathrm{~cm}$, localmente im bricados e com estrutura gradacional (granodecrescência ascendente). Sua extensão lateral é de algumas dezenas de metros. Possui. pouca matriz, constituída por areia de granulação grossa, com a bundância de minerais pesados (granada e turmalina). Os seixos, predominantemente esféricos ou discöides, são principalmente de quartzo e quartzito, estando tambëm presentes seixos de milonito e de rocha quartzo-feldspätica rica em turmalina. Sobre estes paleopavimentos desenvolvem-se barras arenosas com estratificação cruzada. Tais conglomerados são mais frequlentes e espessos, com seixos apresentando maiores dimensões, na base do depósito. No 
topo, de outro lado, são frequentes os niveis argilosos e as es truturas de escavação e preenchimento, que caracterizam as facies de preenchimento de paleocanais.

Tanto as areias como os conglomerados de todos os niveis mostram imaturidade textural (baixa seleção e angulosidade dos seixos) e mineralógica (presença de seixos de rochas graniticas, abundância em felaspatos e presença de minerais instáveis co mo, por exemplo, a granada). E comum a ocorrência de cimento de marcassita, tanto nos arenitos como nos conglomerados (COIMBRA et a.., 1983).

Ocorrem ainda lentes de siltitos de espessura redu zida, normalmente inferior a $1 \mathrm{~m}$, e de pequena continuidade lateral, atingindo de 5 a $10 \mathrm{~m}$ (ATENCIO, 1986). Essas lentes, ricas em restos vegetais, constituem os poucos níveis fossiliferos da Formação Itaquaquecetuba e, segundo RICCOMINI (1989), corresponderiam a megaclastos, intra ou extraclásticos (fig. 3). De acordo com trabalho preliminax de FITTIPALDI et al. (1989), a tafoflora desses megaclastos seria constituida pelos seguintes vegetais : Monstera marginata (est. 6,fig.3), Aquifoliphylzum izicioides (est. 3,fig.7), Casearia serrata (est.1,fig.4), Schizolobium inaequiZaterum (est.2, fig.3),Byrsonima bulzata (est.4,figsl-4;est.15,fig. 1,4-6), Myrcia cf. rostrataformis(est.3, figs.1-4;est.14, figs.2-8), Psidium paulense (est. 2,figs.5,6;est.15,fig.5), Rhamniphyllum ca seariformis (est. 3,figs.6-6a. I,Serjania lancifolialest.5,fig.6; est. 16, fig. 5), Serjania itaquaquecetubensis (est. 5, figs.2-5;est. 16,figs. 3-4), Zanthoxylum granduliferum (est.5,fig.1) e Luehea divari catiformis (est.1, figs. 2,3; est.9, fig. 5). 


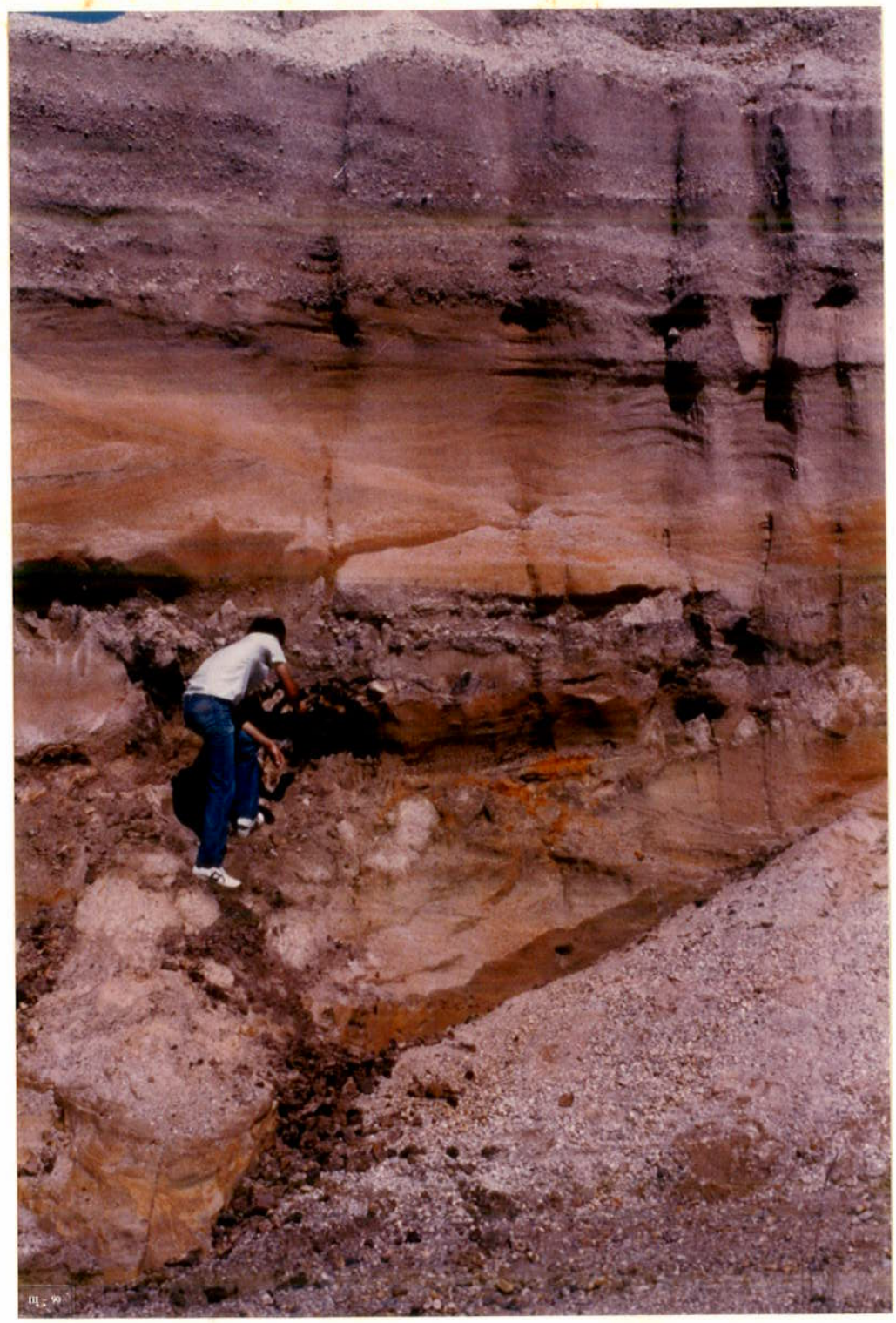

Figura 3 - Megaclasto de dimensões mētri cas, areno-argiloso, de coloração chocolate (porção central da foto), rico em matéria orgânica. Inclui folhas, fragmen tos de caules e estruturas reprodutivas. 
Nas bordas das exposições dos portos de areia, nas proximidades do contacto com o embasamento pré-cambriano, é freqliente a presença de brechas com blocos de dimensões até métricas, constituídos de gnaisse e milonito, seixos e matacões de quartzito, seixos de feldspato e de pegmatito turmalinifero, fragmentos de camadas argilosas e troncos carbonificados (ATEN CIO, 1986). A matriz é essencialmente arenosa grossa, ichegando por vezes a predominar em certos níveis, onde podem aparecer estratificações cruzadas tabulares. Em muitos casos, os limites la terais das exposições dos sedimentos com o embasamento prë-cam briano ocorrem sob forma de contactos de falha (falhas normais), estando aí presentes essas brechas, que configuram cunhas clästi cas. Sua origem está ligada às pulsações tectônicas (ALMEIDA et a1. , 1984).

As situações observadas no campo permitem admitir a hipötese de uma tectônica sin e pós-sedimentar à Formação Itaquaquecetuba. Esta atividade tectônica foi comprovada pelos estu dos de MELO \& PONÇANO (1983), COIMBRA et al. (1983) e ALMETDA et al. (1984), que verificaram a existência de planos de falhamentos normais cortando todo o depósito. As estruturas tectônicas ob servadas constituem-se, em sua quase totalidade, por falhas de carāter normal, ou com rejeito obliquo, típicas de regimes dis tensivos. Falhas inversas são muito raras, sendo evidenciadas através do desnivelamento de camadas sedimentares, bem como por contactos bruscos entre os sedimentos e rochas do embasamento pré- cambriano, através de superfícies de falhas bastante contínuas. Tambëm o adernamento de blocos é, em alguns casos, sugestivo da presença de falhamentos (ALMEIDA et al., 1984). 
Estudos mais recentes têm demonstrado a ocorrên cia de falhas transcorrentes sintectônicas à deposição da Forma ção Itaquaquecetuba, o que a relacionaria com atividade tectônica mais recente, pós-oligocênica, consequentemente mais jovem que a Formação São Paulo (RICCOMINI, 1989). Desta forma, segundo RICCO MINI (op.cit.), a origem da formação estaria relacionada ao soer guimento de blocos controlados por falhas orientadas segundo NNW e ENE, respectivamente antitéticas e sintéticas da fase compressi va, promovendo a remoção da cobertura são Paulo e deposição Ita quaquecetuba em bacias romboidais sobre o embasamento cristalino, com fornecimento de mecaclastos a partir de áxeas elevadas. 


\section{MATERERTAE. E METODOS}

\subsection{MRTIRAL}

o material estudado è constituido por folhas, sementes e frutos carbonificados, provenientes basicamente de dois pontos do "porto" no I da rtaquarefa (fig.4.).

As sementes são provenientes de uma camada de es pessura centimétrica, onde tambëm ocorrem abundantes fragmentos de folhas e de pequenos caules (fig.5). A cominuição das folhas , nesta camada, devido às condições energêticas de transporte, inviabiliza sua identificação taxonômica.

As folhas e frutos foram coletados em prováveis me gaclastos (RICCOMINI, 1989), muito ricos em matéria orgânica. Estes são constituídos por siltes (ocasionalmente arenitos) a folhelhos cinza-marrom escuros. Os fósseis estão distribuídos caoti camente na matriz, não apresentando qualquer orientação aparente. As folhas melhor preservadas estão incluídas nos siltitos, onde frequentemente podem ser encontrados espécimes completos e, em. função da textura fina do sedimento, com detalhes minimos da vena ção. Em alguns casos, as contrapartes das folhas também puderam ser obtidas. Embora a pelicula carbonosa, resultante do processo de carbonificação, esteja sempre presente, raramente a cutícula e pidérmica está preservada, sendo que as tentativas para a prepara 


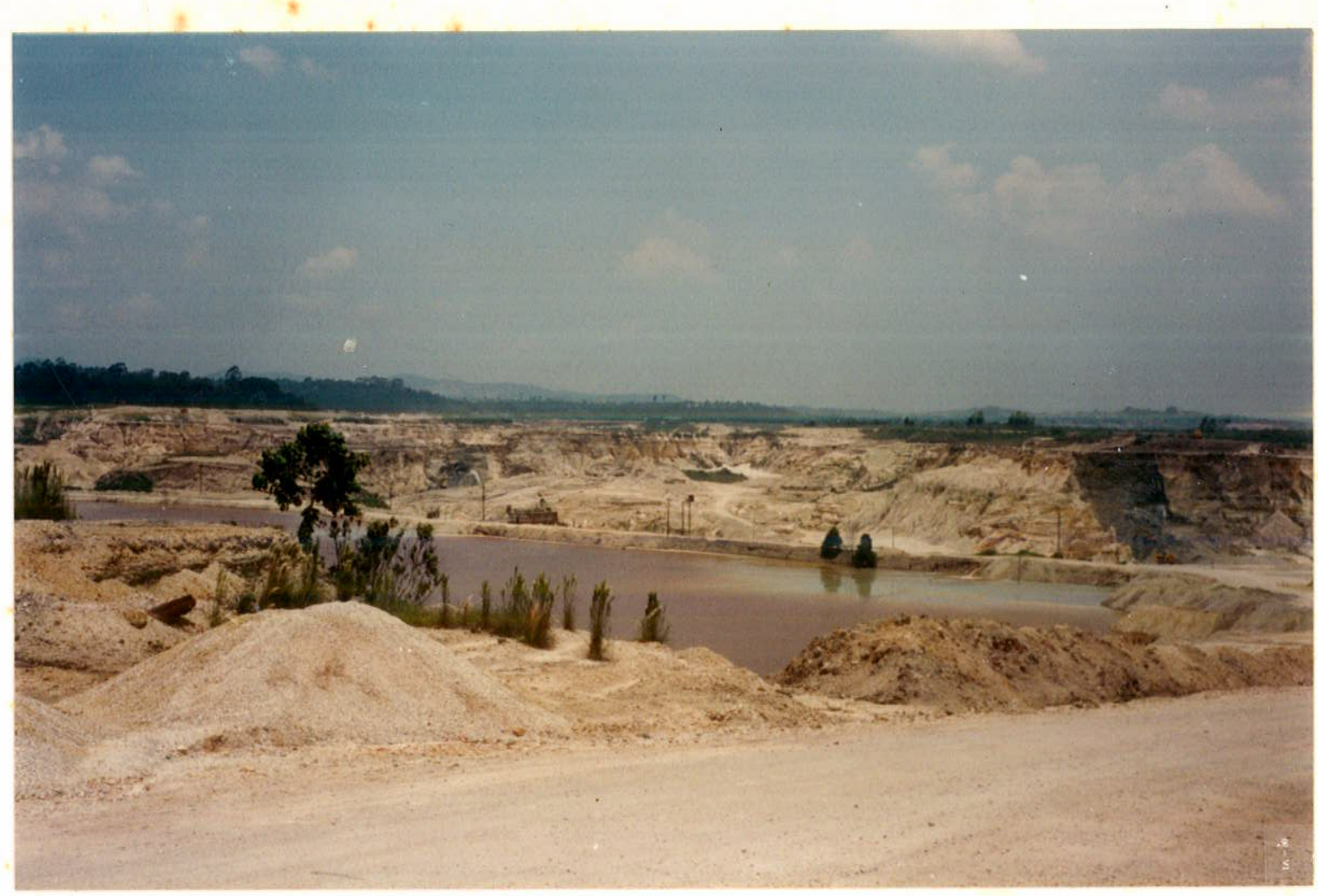

Figura 4 - Vista geral do porto de areia no 1 da Itaquareia, Itaquaquecetuba, SP.

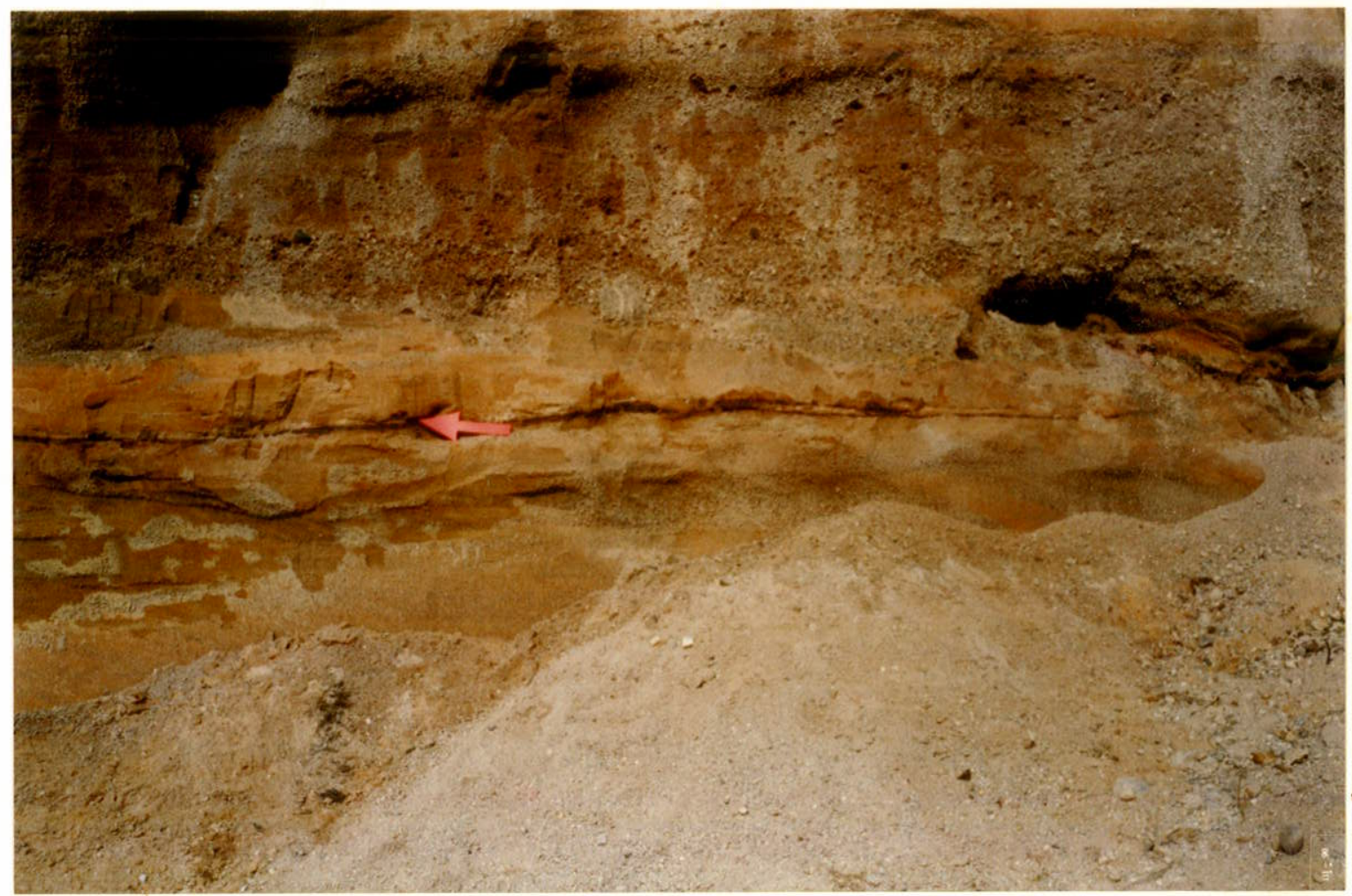

Figura 5 - Camada de espessura centimétrica de concentração de grãos e grânulos oriundos da cominuição dos megaclastos ricos em restos vegetais, intercalada em arenitos fluviais de granulação grossa a média. 
ção de material cuticular não proporcionaram resultados satisfatórios.

Localmente, no interior do megaclasto, são observa dos niveis centimétricos com abundantes restos de folhas superpos tas. O estado fragmentārio deste material, bem como o fato de es tar muito superposto, dificulta sua melhor identificação, de modo que o mesmo não pode ser utilizado para o presente trabalho.

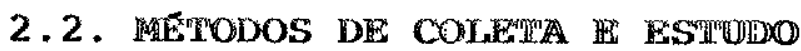

A coleta de material foi realizada, ao longo de vārios meses, com o auxilito de pesquisadores do Instituto de Geociências da USP. Pelo fato dos níveis fossiliferos se situarem subjacentes a depósitos de areia bastante permeáveis, estavam geralmente impregnados de āgua. Esses sedimentos se tornam extremamente quebradiços à medida em que ressecam. Para evitar que os fósseis fossem danificados em função de um ressecamento muito rápido da matriz, foram coletados grandes blocos de sedimento, os quais foram imediatamente envoltos em papel jornal e acondicionados em sacos plásticos. Os blocos foram mantidos em suas embala gens por um espaço de tempo suficiente para que perdessem ägua na turalmente, sendo que, para acelerar o processo, o papel jonnal foi constantemente trocado. Após esta etapa, que normalmente se prolongou por cerca de um mês, os blocos foram abertos no laboratōrio., com o auxilio de martelos e talhadeiras de diferentes ta

manhos. As amostras foram preparadas pelos processos mecânicos uㅡ suais, com o uso de estiletes, espātulas, pincëis e agulhas, sob 
estereomicroscöpio. Os fósseis fragmentados no processo de preparação foram colados com "Colatudo Duco" e, quando necessārio,pro tegidos por uma delgada camada de verniz diluido em acetona. Foram preparadas aproximadamente 450 amostras, que foram numeradas e in corporadas à coleção paleontológica do Departamento de Paleontolo gia e Estratigrafia do Instituto de Geociências da USP. Adicional mente, para efeito de comparação, foram coletados e preparados al guns restos vegetais da Bacia de Taubaté.

Para a identificação, desenhos dos fósseis obtidos atravës de câmara clara, acoplada a um estereomicroscópio, foram comparados com representantes da flora atual, bem como com formas descritas e figuradas na literatura especializada. A comparação com formas atuais foi realizada com material existente no Herbä rio do Departamento de Botânica do Instituto de Biociências da Universidade de são Paulo (SPF), no Hexbārio do Estado "Maria Eney da P.K.Fidalgo", do Instituto de Botânica do Estado de são Paulo (SP), no"Herbarium Rioclarense", do Instituto de Biociências da Universidade Estadual Paulista "Julio de Mesquita Filho" (HRCB) e no Herbário do Jardim Botânico do Rio de Janeiro (RB).

As foros utilizadas para a montagem das :estampas foram obtidas com equipamento existente no Instituto de Geociências da USP e no Departamento de Botânica do Instituto de Biociên cias da USP.

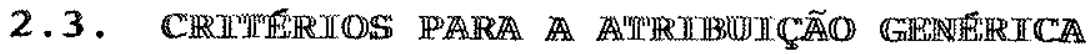


encontrar equivalentes atuais se constitui na filosofia que geral mente tem norteado as pesquisas relacionadas a angiospermas fös seis. Edward w.Berry, um dos mais prolificos investigadores de restos de angiospermas, durante a primeira metade do século, ex pressou claramente essa filosofia em seu trabalho sobre "Floras do Eoceno Inferior do Sudeste da Amërica do Norte": "em um estudo como este a ênfase principal deve ser baseada em comparações com os parentes atuais das formas fósseis..." (BERRY, 1916).

O procedimento padrão na taxonomia de restos folia res de angiospermas tem sido procurar por formas modernas similares e dar à folha fóssil o nome do gênero existente, o qual, apös a devida comparação, é considerado o equivalente mais próximo pos sivel. Assim, as designações taxonômicas têm sido baseadas na melhor aproximação que pode sex feita através da equiparação de folhas fósseis e modernas. Com maior frequência, o nome genérico de uma forma atual é usado para a forma fóssil, embora também seja comum alterar ligeiramente o nome genérico existente. Isto è feito pela adição de um sufixo como ites, phyzzum ou opsis(Myri cipites, Myrciophyzzum e Castanopsis, por exemplol, ou de um prefixo como pseudo ou para (Pseudocotyzedon e Paranymphaea, por exemplo)

De acordo com esse procedimento, paleobotânicos apresentaram listas florísticas do Cretáceo e Terciário Inferior dominađas por gêneros e familias de angiospermas modernas.DILCHER (1974), por exemplo, em uma tabulação de flora.s selecionadas de idade cretácea e terciária inferior, verificou que 93\% dos taxons genéricos atribuídos às folhas fósseis tinham nomes genéricos mo- 
dernos ou ligeiramente modificados. No "Catalogue of the Cenozoic plants of North America through 1950" (LANOTTE, 1952), estão relacionados representantes de 147 familias de angiospermas, de idade variando do Cretáceo ao Pleistoceno, que foram atribuidos a gêne ros atuais.

Entretanto, apesar desse procedimento ser extrema -; mente comum até os dias de hoje, seu uso envolve a discussão de alguns aspectos.

DILCHER (1974), embora admitindo a presença de gêneros modernos na flora do cretáceo e Terciário Inferior, levanta uma série de restrições à atribuição de fósseis de angiospermas a taxons atuais apenas com base em similaridades superficiais entre as folhas. DILCHER (op.cit.) lembra que o reconhecimento de gêne ros e familias modernos nas folhas fösseis do cretácêo Inferior e Médio, bem como do Paleogeno, tem sido baseado em similaridade das feições gerais destas folhas com formas modernas. Pouco uso tem si do feito dos detalhes da venação ou das feições cuticulares. Quando estes aspectos são tambëm considerados, a identificação pode ser mais precisa. SHEFFY (1972) afirma que apenas quando os $:$ taxons individuais são estudados em detalhe, e a morfologia das foIhas de gêneros modernos é conhecida completamente, podem ser feitas identificações mais precisas. E possível, inclusive, que mui tos taxonomistas usem, hoje em dia, nomes genéricos atribuídos pelos primeiros pesquisadores sem um verdadeiro entendimento da natu reza precisa do material fössil descrito. No momento, as técnicas frequentemente não acuradas usados por aqueles pesquisadores têm sido questionadas. 
Na opinião de STEBBINS (1950), "as impressões fo liares são as menos diagnósticas de todas as partes da planta". GOOD (1966, segundo DILCHER, 1974) expressa dūvida similar quando afirma que "as folhas são os mais plästicos e variáveis de todos os örgãos da planta e que identificação e registros baseados so mente em folhas isoladas devem ser considerados com cuidado, e tratados até certo ponto como provisórios, requerendo confirmação quando meios para isto se tornam disponíveis".

Jä MOUTON (1985) defende a utilização dos caracteres foliares no estudo de angiospermas fósseis, demonstrando que "é possivel identificax uma espëcie atravēs de suas folhas". HICKEY (1979), por sua vez, considera a morfologia foliar como uma "ferramenta virtualmente inexplorada para estudos sistemäticos de dicotiledôneas".

Estudos comparativos, de outro lado, têm demons trado que certas angiospermas do Terciārio Inferior são quase indistinguiveis de equivalentes atuais, com base não apenas nos padrões de venação, mas tambēm nas feições cuticulares (TAYLoR, 1981). E o caso, por exemplo de phizodendron encontrado na Forma ção Clairbone, do Eoceno Médio de Kentucky e Tennesse, E.U.A. ,que é praticamente idêntico ao seu representante atual. Considerando que a cutícula representa uma série de importantes caracteristi cas de interesse taxonômico, a nível específico inclusive, esse fato è de grande relevāncia.

A aplicação de novas técnicas em angiospermas fósseis tem comprovado a similaridade entre formas fósseis e seus 
correspondentes atuais. Uma técnica, amplamente utilizada para o estudo de sistemätica vegetal, e que tem sido aplicada aos fösseis, envolve o uso de perfis químicos orgânicos. Em um estudo de NIKLAS \& GIANNASI (1978), espécimes de folhas de cinco gêneros do Mioceno (Acer, Celtus, Querous, Ulmus e zelkova) foram morfologica e quimicamente comparados com seus correspondentes atuais. A composição química dos flavonōides, junto com outros constituin tes químicos dos fósseis (parafinas, esteranos, triterpenos e ácí dos graxos) indicou um alto grau de correlação entre os fösseis e as formas modernas.

Segundo BURNHAN (1986), em seu estudo sobre Ulma ceae do Terciārio, a circunscrição de um novo gênero pode ser jus tificada se: 1) o espécime fóssil è claramente intermediārio,combinando caracteres de gêneros conhecidos, sendo que neste caso po de ser uma forma ancestral ou híbrida; 2) caracteres não ocorrentes em qualquer um dos gêneros viventes ocorrem no espēcime fós sil.

Pelo exposto,é cabível admitir que, conquanto existam numerosas restrições à atribuição de angiospermas fósseis a gêneros atuais, existem alguns argumentos que podem suportar este procedi mento. Considerando este fato, bem como a grande semelhança que a tafoflora estudada apresenta, inclusive a nível específico, com associações vegetais hoje presentes nas matas pluviais do Estado de são paulo, optou-se pela adoção do critério de BURNHAN (1986). Desta forma, em sua totalidade, os fósseis foram atribuidos a gêneros atuais. Todavia, foi sempre proposto um novo epiteto es pecifico, mesmo nos casos em que a semelhança era muito grande, considerando a impossibilidade das espécies permanecerem inaltera 
das, sob pressões ambientais e genéticas, ao longo de milhões de anos (BECKER, 1969).

\section{4. CARACTERTZAÇÃO DA ARQUTTETURA FOLIAR}

A forma geral das folhas de angiospermas, incluin-

do feições como tamanho, natureza das margens, forma do äpice, bạ se e pecíolo, posição das glândulas e natureza da venação, tem sido sempre muito importante para a descrição de folhas fósseis. As feições gerais, na maioria dos casos, são facilmente determina das, e algumas combinações de feições particulares parecer ser uㅡ nicas para certos taxons existentes (DILCHER, 1974). O uso de fei ções particulares, tal como a presença de uma base inequilateral e peciolo curto para sugerir que alguns espécimes fösseis se cons tituem em folílos, e a presença de um peciolo inflado para indicar afinidades com determinadas familias, tem sido muito comum em estudos de angiospermas fósseis (DILCHER, op.cit.).

Devido às dificuldades de se obter folhas de angiospermas atuais, muitos dos trabalhos foram baseados em simples comparações com ilustrações disponiveis na literatura. Este proce dimento não possibilita uma comparação critica dos detalhes da morfologia foliar, tais como venação de 49 e 59 ordens, ou feições cuticulares, porque estas informações raramente são incluíar em publicações a respeito de floras fósseis ou modernas. "Conforme destaca WOLFE (1972), o uso de tal procedimento para a identifica ६̧ão de folhas de dicotiledôneas fósseis levou a numerosas conclum sōes floristicas, vegetacionais e evolucionärias equivocadas. 
A classificação de espécimes fósseis usando forma geral da folha, sem considerações dos detalhes da venação, : e/ou caracteres cuticulares, produz resultados incertos. Entretanto, quando todos estes aspectos são estudados em conjunto, podem fornecer informações muito fidedignas a respeito de angiospemas fós seis. Desta forma, o paleobotânico, na identificação de folthas fósseis, está se baseando em padrões de venação de ordens cada vez mais altas. Se a venação de terceira ordem não está preservada, as folhas fósseis frequentemente não podem ser identificadas (MAC GI NITIE, 1969).

Para que a vaxiabilidade de um taxon seja entendida, seria recomendável o estudo da forma geral, detalhes da venação e anatomia cuticular de um grande nümero de espëcimes. Entretanto, nem sempre é possível ter à disposição um número elevado de espécimes, ou espécimes com a cutícula preservada, particular mente no caso dos fósseis terciārios brasileiros, que quase sem pre se apresentam na forma de impressões. Embora a cutícula estivesse preservada em alguns dos fósseis estudados "! no presente trabalho, as tentativas de montagem de lâminas não foram bem suce diàas, em função do estado fragmentário do material cuticular. Con siderando que pequenos fragmentos são desprovidos de valor diagnōsticos, não foi possivel sua utilização com finalidades taxonô micas.

E cabivel admitir que grande parte das restrições ao uso taxonômico de venação seja devida à falta de uma classificação adequada das feições morfológicas foliares. Com base na ausência de uma classificação detalhada, pađronizada e não ambígua daquelas feições, muitos dos pesquisadores se limitaram a breves 
descrições dos aspectos mais gerais da planta, o que resultou em una porcentagem provavelmente alta de atribuições genéricas incor retas, especialmente no caso de folhas mais antigas que o Terciā rio Médio (HICKEY, 1973).

Sistemas de terminologia descritiva da forma geral e padrões de venação de folhas de angiospermas foram apresentados por paleobotânicos e taxonomistas, como por exemplo ErTINGSHAUSEN (1861), KERNER VON MARILAUN (1895), GOEBEL (1905), IAM (1925) , TROLL (1938) e LEE (1948).

O sistema mais compreensivo e utilizävel foi publi cado por HICKEY (1979), como resultado de esforços para encontrar critérios seguros para identificar folhas de angiospermas fósseis. HICKEY (op.cit.) combinou classificações de arquitetura foliar , previamente publicadas, com sua experiência referente a caracte res foliares de folhas atuais e fósseis, para elaborar uma classi ficação detalhada, de grande importância para padronizar observações e terminologia de arquitetura foliar, tanto para paleobotâni cos como para taxonomistas.

A justificativa essencial para essa classificação reside no fato de que vários taxons de dicotiledôneas têm follhas possuindo padrões consistentes e identificáveis de organização de arquitetura foliar, em todos os niveis, de sub-classe à espécie (HTCKEY \& WOLFE, 1975).

Na caracterização da arquitetura foliar foi utilizado, portanto, o esquema de HICKEY (1979). Os principais elemen- 
tos utilizados para esta caracterização, disponiveis na maionia dos espēcimes estudados, foram forma da folha, configuração da margem, forma do ápice, base e pecíolo, padrão de venação e posição das glândulas (figura 6). Para fins de estudo taxonômico, foram utilizados somente os fósseis que apresentavam pelo menos três ordens de venação preservada, ou aqueles com combinações ünicas e inconfundiveis de feições particulares (representantes das famí lias Tiliaceae e Melastomaceae, por exemplo).

Para a medida đa ārea foliar, foi empregado o processo de CAIN et al (1956), segundo o qual a superficie foliar é $2 / 3$ da ärea retangular do comprimento por largura. A classifica ção da ārea medida foi feita de acordo com o sistema de RAUNKIAER (1934).

Para a taxonomia das angiospermas, foi usado o sis tema de classificação de CRONQUIST (1981), perfeitamente compativel com o registro fóssil. No caso das briófitas e pteridófitas, foram adotados, respectivamente, os sistemas de SCHUSTER (1984) e TRYON \& TRYON (1982). 


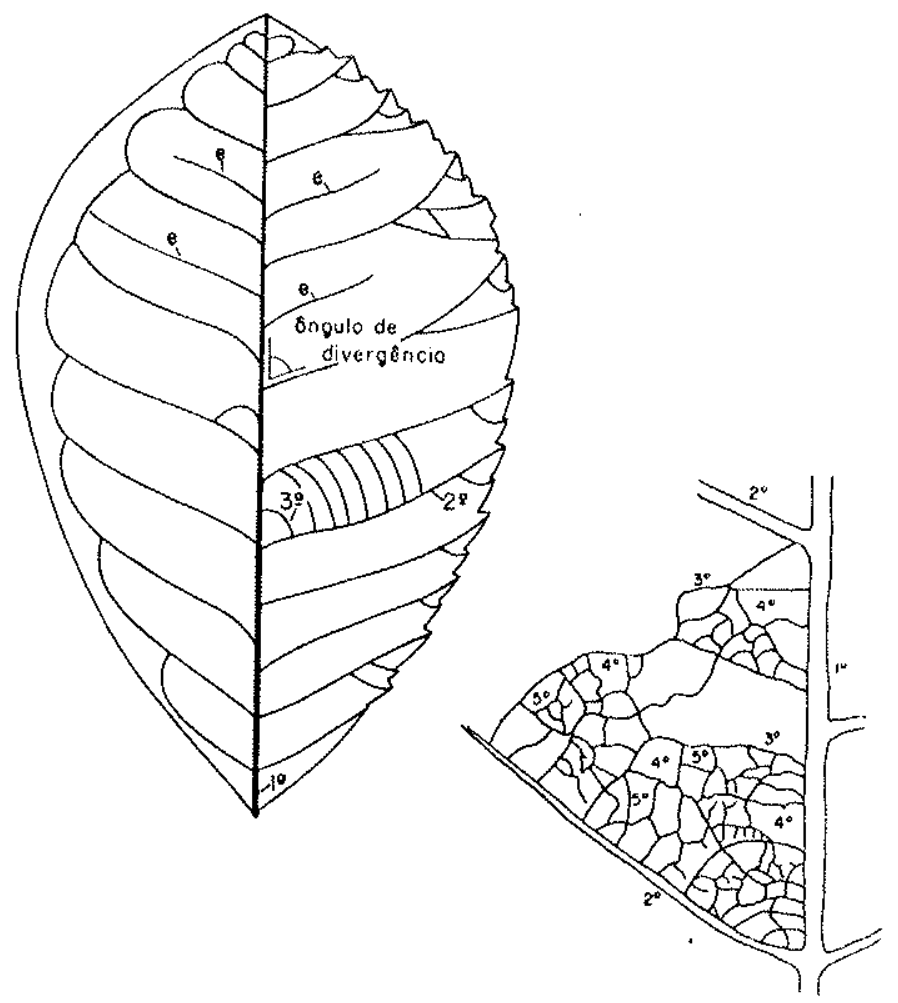

Figura 6 - Ordens de nervação (modi ficado de HICKEY, 1979). 


\title{
SISPUERATICA
}

\section{I. BRTOFTMAS}

\author{
Divisão BRIOPHYTA \\ Classe HEPATICOPSIDA \\ Ordem JUNGERMANNIALES \\ Subordem JUNGERMANNTINEAE \\ Família BATANTIOPSIDACEAE \\ Subfamilia ISOTACHIDOIDEAE \\ Gênero Isotachis Mitt.
}

Comentários - A ordem Jungermanniales é a maior dentre as hepáticas. São conhecidos cerca de 190 gêneros, a maioria dos quais tem ampla distribuição nas regiões tropicais (JoLy, 1983). A ordem inclui formas talosas e foliosas (acróginas). As formas acróginas possuem caractexisticamente um caulíaio folioso com simetria bilateral, guarnecido por duas séries de filídios. Frequentemente, sobre a face ventral do caulidio, pode ser observada uma terceira sēxie de filídios de forma particular, denominádos anfigästxios (JOVET-AST, 1967).

Gênero Isotachis Mitt.

Isotachis simonesi sp. nov.

(est. 7 ; figs. 1-4) 
Holötipo - GP/3E-5189; localidade-tipo: Porto de areia no 1 da Itaquareia, Itaquaquecetuba, SP.

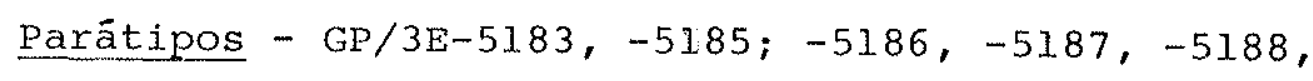

$-5192$.

Epiteto especifico - espécie dedicada ao paleontölogo Marcello Guimarães Simões, do Instituto de Biociências da UNESP de Botucatu.

Diagnose especifica - Gametófito prostrado, retili neo ou ligeiramente curvado. Caulidio simples, com filílios imbri cados, com āpice bífido, recurvado, base obtusa a arredondada.

Descrição - Gametófito prostrado, retilineo ou li geiramente curvado, com comprimento máximo de 1,3 cm. Caulídio sim ples, com duas sēries de filidios dorsais imbricados; filídios com cerca de $1 \mathrm{~mm}$ de comprimento, ápice bifido, recurvado, base obtusa a arredondada. Anfigästrios e rizöides não observados.

Distribuição estratigráfica - De acordo com STEWART (1985), as Jungermanniales teriam surgido pouco antes do inïcio do Terciário. No que diz respeito ao gênero Isotachis, porém, esta é possivelmente a primeira ocorrência no estado fóssil, visto que não foram encontradas referências na literatura paleobotânica.

Para o Brasil, esta é a primeira briófita fóssil descrita, embora BARBOSA \& ALMEIDA (1953) tenham assinalado, na Formação Corumbatai, restos duvidosamente atribuídos a Marchantites sp. 
Discussão - Estes Eósseis, provavelmente em função de sua natureza delicada, são relativamente raros na tafoflora da Formação Itaquaquecetuba.

Embora procedentes dos mesmos blocos que contém as folhas, não ocorrem diretamente associados com elas. Nas poucas amostras obtidas, os espēcimes aparecem em grandes concentrações, juntamente com cauliaios de provăveis briófitas talosas, não tendo sido vexificada a presença de outros restos orgânicos identificāveis em associação direta.

A presença de um caulídio folioso, com simetria bi lateral, permite atribuir prontamente o fóssil às Jungermannia les acróginas. A disposição e o formato dos fillílios, por sua vez, possibilita a atribuição ao gênero Isotachis.

\subsection{PTERTDOFTTAS}

Divisão PTERIDOPHYTA

Classe FILICOPSIDA

Subclasse POLYPODITDAE

Ordem POLYPODTALES

Subordem POLYPODIINEAE

Familia DENNSTAEDTIACEAE

- Tribo LINDSAEEAE

Comentários - A família Dennstaedtiaceae compreende 17 gêneros, de distribuição pantropical, com alguns poucos se extendendo para regiões temperadas. o grupo é caracterizado por caules rastejantes portando grandes folhas compostas, com soros 
marginais ou sub-marginais providos de indüsio (TRYON \& TRYON 1982).

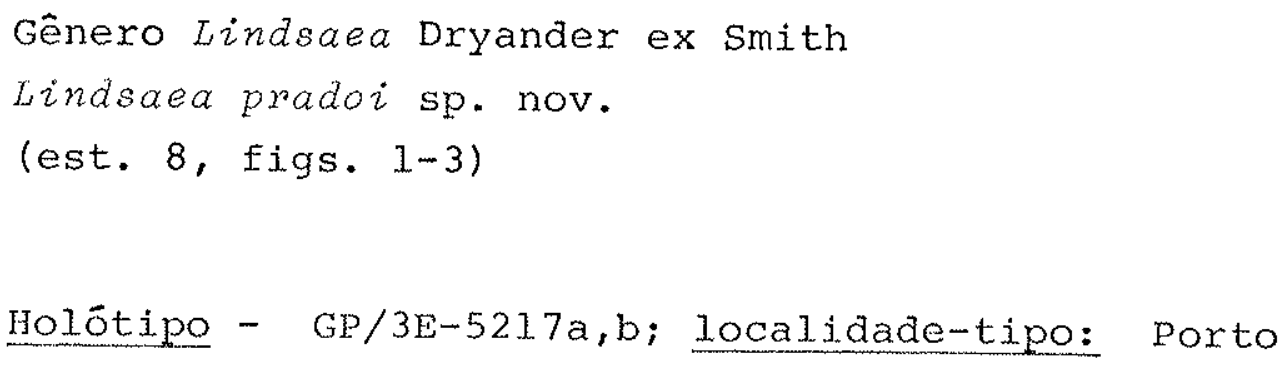
de areia no 1 da Itaquareia, Itaquaquecetuba, SP.

Epiteto especifico - espēcie dedicada ao botânico Jefferson Prado, pós-graduando do Departamento de Botânica do Inṣ tituto de Biociências da USP.

Diagnose especifica - Folha pinada, pinas sub-trapeziformes, margem lisa. Venação livxe, bifurcada, partindo da base dos segmentos, com ápice ligeiramente expandido. Indüsio inteiro, semi-lunar, crenulado.

Descrição - Pina incompleta, com folíolos férteis, provavelmente correspondentes aos basais, sub-trapeziformes, com $1,2 \mathrm{~cm}$ de comprimento por $1,1 \mathrm{~cm}$ de largura, margem lisa. Venação livre, bifurcada, partindo da base dos segmentos, com ápice li geiramente expandido. Indúsio inteiro, semi-lunar, crenulado,distinto da margem lisa.

\section{Distribuição estratigräfica - Os registros fósseis} da familia Dennstaedtiaceae remontam ao Paleoceno (CHING, 1978). o gênero Lindsaea, ao que tudo indica, ë pela primeira vez assinala do no estado fóssil. 
Discussão - o padrão de nervação e a presença de indúsio situam este fóssil nas Filicopsida. O formato dos folío los é compatível com aqueles encontrados no gênero Lindsaea, como apresentado na revisão de KRAMER (1957).

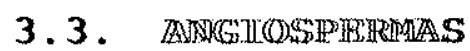

\subsubsection{HOHWHAS}

Divisão MAGNOLIOPHYTA

Classe MAGNOLIOPSIDA

Subclasse MAGNOLIIDAE

Ordem LAURALES

Familia LAURACEAE

Comentärios - A família Lauraceae ë constituída por cerca de 32 gêneros e 2.500 espécies atuais que, embora pos sam ser encontrados em todas as regiões tropicais e subtropi cais do mundo, especialmente em florestas tropicais úmidas,apresentam os principais centros de dispersão no Brasil e sudeste da Asia (HEYWOOD, 1979). No Brasil, a familia está representada por 19 gêneros e aproximadamente 390 espécies (BARROSO,1978), de hábito lenhoso, arbōreo ou arbustivo (HEYWOOD, op.cit.). Usual mente as laurāceas apresentam folhas simples, coriáceas, com max gem inteira e.padrão de nervação broquidódromo; cavidades oleífe ras são comuns (HICKEY \& WOLFE, 1975; HEYWOOD, op.cit.). As Lau raceae possuem afinidades com as Monimiaceae e com as Magnolia ceae (HEYWOOD, op.cit.). 
Gênero Ocotea Aublet

ocotea pulchezliformis sp. nov.

(est. 1, fig. 1; est. 9, fig.3)

Holótipo - GP/3E-5134; localidade-tipo: Porto de areia no 1 da Itaquareia, Itaquaquecetuba, sP.

Epiteto específico - pulchelliformis alude à espécie atual ocotea puzchezza, muito similar ao fössil estudado.

Diagnose específica - Folha simëtrica, eliptica,ba se aguda, margem inteira. Padrão de nervação eucamptódromo na por ção inferior e broquidódromo na porção superior da folha; nervura primäria de calibre moderađo, retilínea; nervuras secundárias de calibre moderado divergem da mediana de maneira alterna, segundo ângulos agudos estreitos a moderados (42-520); nervuras terciá rias, quaternārias e quintenārias com emergência ortogonal; aréolas com desenvolvimento perfeito, predominantemente pentagonais, com vênulas livres, simples ou ramificadas.

Descrição - Folha simëtrica, com $3,2 \mathrm{~cm}$ de comprimento por $1,6 \mathrm{~cm}$ de largura, contorno eliptico $(\mathrm{c} / 1=2), 1$ imbo com numerosas estruturas circulares de tamanho reduzido, äpice não preservado, base aguda, margem inteira e pecíolo não preservado. Pađãão de nerviação eucamptódromo na porção inferior e broquidōdro mo na porção superior da folha; nervura primária de calibre moderado, retilinea, afilando ligeiramente em đireção ao äpice; nervuras secundārias, em nümero de 5 na parte preservada, divergem da mediana de maneira alterna, segundo ângulos agudos estreitos a mo derados (42-520); são nervuras moderadas, arqueadas desde sua di 
vergência, ascendentes em direção ao äpice, unindo-se, na metade superior da folha, às sobrejacentes, próximo à margem; nenvuras terciārias formando denso e evidente retículo; nervuras terciärias, quaternārias e quintenārias com emergência ortogonal; arēolas com desenvolvimento perfeito, com forma e tamanho variáveis, predominantemente pentagonais, algumas com vênulas livres, outras com vênulas simples ou ramificadas uma vez.

Distribuição estratigräfica - o gênero ocotea, segundo KNOwLTON (1924), já seria assinalado em rochas datadas do Paleoceno. Para a flora cenozóica do Brasil, esta é a primeira o corxência, embora outras lauräceas tenham sido registradas anteriormente em sedimentos de idade variando do Eoceno ao plioceno (GORCEIX, I884; HOJLICK \& BERRY, 1924; BERRY, 1937; DUARTE, 1972).

Discussão - Conforme salienta BERRY (1916), a iden tificação dos gêneros da familia Lauraceae está envolta em dificuldades quase intransponíveis. No entanto, o fóssil aqui descrito, representado por um ūnico espécime excepcionalmente bem preservado, é muito semelhante a ocotea pulchella, uma laurácea bas tante comum na Mata Atlântica. Esta semelhança diz respeito à for ma, dimensões, textura e nervação, inclusive a nível de arēolas.A diferença mais marcante em relação a o.pulchelza está relacionada à presença de estruturas circulares que eventualmente pode riam corresponider a glândulas. Restam düvidas, porém, a respeito da verdadeira natureza dessas estruturas, jä que um exame mais minucioso sugere que elas estão, na verdade, superpostas ao fós .sil, podendo se constituir em marcas de galhas, conforme serä tra tado posteriormente. 
Apesar da possibilidade da folha ser glandulifera, as demais afinidades morfológicas sugerem fortemente tratar-se do gênero ocotea. Destauforma, parece preferivel atribuir o fóssil a este gênero.

\author{
Subclasse DILLENIIDAE \\ Ordem MALVALES \\ Familia TILIACEAE
}

Comentārios - A familia Tiliaceae è amplamentedistribuída em todas as regiões tropicais do mundo, especialmente América: do Sul, Africa e sudeste da Asia. Algumas poucas formas se extendem para regiões temperadas da Europa e América do Norte (HEYWOOD, 1979). Os dois principais centros de dispersão estão no sul da Africa e Brasil (BARRoso, 1978). A familia é constituída por cerca de 41 gêneros e 400 espécies, com plantas herbäceas ou lenhosas, arbustivas ou arbóreas (JOLY, 1983; HEYWOOD, op.cit.). os representantes da familia são caracterizados por folhas simples, margem com dentes não glandulares, padrão de nervação actinōdromo e pequenas estipulas na base (HICKEY \& WOLFE, 1975; HEYWOOD, 1979).

Gênero Luehea willdenow

Luehea divaricatiformis Fittipaldi, simões, Giuliet

- ti \& Pirani, 1989.

(est. 1, figs. 2,3; est.9, fig.5)

Luehea divaricatiformis Fittipaldi et a1., 1989,p. 192-193, figs. 13, 28;Fittipaldi \& Simões,1989, p. 28, est. 1, fig. m. 
Material - GP/3E-4804, -5250; procedência - porto de areia no I da Itaquareia, Itaquaquecetuba, SP.

Descrição - Folha assimētrica, com $2,3 \mathrm{~cm}$ de compri mento por $1,9 \mathrm{~cm}$ de largura na parte preservada, contorno aparentemente oval ou eljiptico, ápice não preservado, base muito assimẹ trica, sendo que, de um lado da nervura mediana, o limbo tem base aguda e, do outro, base arredondada, margem serrada. Padrão: de nervação actinódromo basal, com 3 nervuras primärias de : calibre forte divergindo em ângulos agudos estreitos (22-300) da base do limbo; nervuras secundärias de calibre moderado, mais ou menos pa ralelas, unindo as primärias, formando ângulos retos ou aproximadamente retos; nervuras terciárias reticuladas ao acaso.

\section{Distribuição estratigrāfica - A família Tiliaceae,} segundo DOLIANITT (1950), surgiu no Cretāceo Inferior, : enquanto que o gênero Luehea é registrado a partir do Eoceno (BERRY,1916). No Cenozóico do Brasil, o gênero também está representado ha Ba cia de Fonseca, de provāvel idade eocênica (DOLIANITI, op.cit.).

Discussão - o fóssil aqui estudado corresponde cer tamente a Luehea divaricatiformis, descrita por FITTIPALDI et al. (1989), com base em material procedente do mesmo local. Conforme destacam estes autores, a nervação actinödroma, com nervuras se cundärias paralelas, a base assimétrica e a margem serrada colo cam imediatamente esta folha nas Tiliaceae e no gênero Luehea. A espécie atual que mostra maior afinidade é L. divaricata Mart., o "açoita-cavalo", muito comum nas matas do Estado de são paulo. 
veu a nova espécie L.roxoi. L. divaricatiformis é claramente dis tinta de L.roxoi porque esta apresenta nervuras secundárias al ternas e uma margem mais finamente serrada.

\author{
Subclasse ROSIDAE \\ Ordem FABALES \\ Familia MIMOSACEAE
}

Comentários - A Familia Mimosaceae compreende cer ca de 56 gêneros, que abrangem de 500 a 3.000 espécies, de hábito arbustivo ou arböreo, distribuidas principalmente nas regiões tro picais e subtropicais do globo (HEYWOOD, 1979). Apresentam folhas frequentemente duplamente pinadas, com margem inteira e padrão de nervação broquidódromo (HICKEY \& WOLFE, 1975; JOLY. 1983). E con siderada por muitos autores como uma subfamijia das Leguminosae.

Gênero Piptadenia Bentham

Piptadenia tertiaria sp. nov.

(est. 10, figs. 1-3)

Holótipo - GP/3E-5130; localidade-tipo: Porto de areia no 1 da Itaquareia, Itaquaquecetuba, SP.

$$
\begin{array}{r}
\text { Parätipos }- \text { GP/3E-5117, }-5119,-5120,-5122,-5123, \\
-5124,-5127,-5129,-5131,-5134,-5135,-5137,-5146,-5343 .
\end{array}
$$

Epiteto específico - tertiaria refere-se à idade dos sedimentos fossiliferos. 
Diagnose especifica - Folha pinada, foliolos 1ineares falcados, opostos, de tamanho variável (4-6 mm de compri mento por 1,0 - 1,5 mm de largura), ápice agudo, base marcadamente assimétrica, margem inteira. Nervura primária de calibre forte, excêntrica; nervuras secundārias inconspícuas.

Descrição - Folha provavelmente pinada, folíolos (foliólulos?) Iineares falcados, provavelmente opostos, de tama nho variāvel (4-6 mm de comprimento por 1,0 - 1,5 mm de largura), āpice agudo, base marcadamente assimëtrica, margem inteira. Nervu ra primäria de calibre forte, excêntrica; nervuras secundārias in conspicuas.

\section{Distribuição estratigráfica - A família Mimosaceae} está representada desde o Paleoceno-Eoceno (CREPET \& TAYLOR,1985). Folhas de Piptadenia, no entanto, são desconhecidas no estado fós sil, embora troncos referíveis ao gênero tenham sido identifica dos na Formação Itaquaquecetuba por SUGUIO (1971) e suguio \& MUSSA (1978).

Discussão - Este material é relativamente abundante, sendo representado por foliolos quase sempre isolados. Os foliolos ou folioblulos mostram nitidas afinidades com as legumino sas e, em especial, com as mimosáceas. Dentre os numerosos gêne ros viventes no Brasil, o que mais se assemelha, devido ao aspecto falciforme do folíolo, è piptadenia, embora outros gêneros tam bém possam ser considerados afins. 
Famülia CAESALPINTACEAE

Comentários - Esta familia compreende cerca de 180 gêneros e $2.500-3.000$ espëcies atuais, distribuỉos nas regiões tropicais e subtropicais de todo o mundo (HEYWOOD, 1979). Inclui plantas subarbustivas, arbustivas, arböreas ou trepadeiras de matas, bem como raras ervas (JoLy, 1983). Apresentam folhas com postas, em geral simplesmente pinadas, ocorrendo também duplamen te pinadas, com margem inteira e padrão de nervação broquidódromo (HICKEY \& WOLEE, 1975; JOLY, op.cit.).

\author{
Gênero Cassia I.jnnaeus \\ Cassia roszeri sp.nov. \\ (est. 2, fig. 4; est.11, figs.1-4)
}

Holōtipo - GP/3E-5237; localidade-tipo: Porto de

areia no 1 da Itaquareia, Itaquaquecetuba, SP.

$$
\text { Parátipo - GP/3E-5112 }
$$

Epiteto específico - espēcie dedicada ao prof. Dr. Oscar Rösler, do Instituto de Geociências da USP.

Diagnose especifica - Folíolo simétrico, ovado-lanceo lado, āpice agudo, base obtusa assimëtrica, margem inteira. Nerva ção broquidödroma; nervura primāria de calibre forte, retilinea ; nervuras secundärias alternas, de calibre moderado, divergem da primária formando ângulos agudos moderados a largos (51-760); ner- 
vuras terciārias reticuladas ao acaso.

Descrição - Folíolo simétrico, com $3,4 \mathrm{~cm}$ de compri mento por $1,2 \mathrm{~cm}$ de largura, contorno ovado-lanceolado $(\mathrm{c} / 1=3)$, á pice provavelmente agudo, base obtusa assimetrica, margem inteira, pecíolo não conservado. Padrão de nervação camptōaromo - broquidō dromo; nervura primāria de calibre forte, retilínea, afilando ligeiramente na metade superior da folha; nervuras secundarias, alternas, de calibre moderado, divergem da primäria formando ângu los agudos moderados a largos $(51-760)$; são nervuras ascendentes em direção ao āpice; nervuras terciärias reticuladas ao acaso.

\section{Distribuição estratigráfica - segundo BERRY (1935),} - gênero Cassia surgiu no Cretäceo superior da América do Norte. No estado fóssil apresenta mais de 100 espécies descritas, sen do que alguns folíolos fósseis são praticamente indistinguíveis das formas recentes. No Brasil, o gênero foi assinalado nas bacias de Fonseca (BERRY, 1935) e Gandarela (DUARTE \& MELO FILHA, 1980), de provável idade eocênica, no Plioceno da Bahia (HOLLICK \& BERRY, 1924), no Plioceno do Acre (BERRY, 1937) e no Jazigo Vargem Grande do sul, atribuído ao Quaternārio (DUARTE \& REZENDE-MARTINS, 1983).

Discussão - Este fóssil apresenta claras afinidades com as leguminosas. Sua forma geral e detalhes de nervação asso ciam-no com folíolos que têm sido normalmente atribuídos ao gênero Cassia, embora muitas vezes sem evidência suficiente, desde que existem muitos outros gêneros de leguminosas que apresentam fo líolos similares. Entretanto, considerando que o fóssil è muito 
semelhante a formas que têm sido consistentemente atribuidas Cassia, parece preferivel referílo a este gênero.

De outro lado, a variação observada em Cassia é considerävel, mesmo em folhas individuais de algumas espécies. Des ta forma, deve ser ressaltado que a espécie aqui descrita, baseada em poucos espëcimes, pode não refletir a variação intraespecifica eventualmente existente no taxon, tanto em termos de tamanho como de forma.

Conforme visto anteriormente, Cassia está bem re presentado na flora cenozóica do Brasil.

Para o Pljoceno da Bahia, HOLLICK \& BERRY (1924), descreveram C.marahiana. A espécie aqui descrita difere de C.marahiana principalmente pelo tipo de ápice e padrão de nerva ção.

Na Bacia de Fonseca (MG) ocorrem C.fonsecana e C.obtusatafolia, propostas por BERRY (1935). A julgar pelas ilustrações de BERRY (op.cit.), C.rosleri parece ser semelhante a $C$. fonsecana no formato geral, diferindo, contudo, no padrão de nervação. A espécie aqui descrita, de outro lado, é claramente dis tinta de C.obtusatafolia, não só pelo padrão de nervação, mas tambèm pelo tipo de ápice, que è ligeiramente emarginado e inequi lateral nesta ültima.

No Plioceno do Acre, BARRY (1937) assinalou a presença de c.aguaytiensis, que ele havia descrito anteriormente pa- 
ra o Plioceno do Peru (BERRY, 1925). Das formas descritas para o Brasil, C.aguaytiensis é certamente a que mais se assemelha a $C$. rosleri. A semelhança entre as duas espécies é bastante grande no formato geral, no padrão de nervação e no ângulo de divergên cia das nervuras secundārias. A espécie da Formação Itaquaquecetuba, porém, apresenta base nitidamente mais assimëtrica e formato ligeiramente mais alongado.

Na Bacia de Gandarela (MG), DUARTE \& MELO FILHA(1980) descreveram c.adumbrata. Infelizmente, o material figurado pe las autoras estâ muito mal preservado, dificultando a comparação com o fóssil aqui descrito. Aparentemente, c.roszeri apresenta um formato mais alongado que c.adumbrata.

Para o Jazigo Vargem Grande do Sul (SP), DUARTE \& REZENDE-MARTINS(1983) descreveram C.parkerii, C.elziptica e C. parabicapsuzaris. Com base nas descrições e ilustrações de DUARTE \& REZENDE-MARTINS (op.cit.), ë possivel constatar apenas que C.roslexi difere de C.parkerii no formato geral, já que o pa đrão de nervação da espécie de Vargem Grande do sul não estā preservado. No padrão gexal de nervação e no tipo de base c.ros zeri apresenta similaridades com C.parabicapsularis e C.elziptica, di ferindo porém pelos detalhes da nervação e pelo formato mais alon gado.

O holótipo de C.rosteri apresenta marcas de possi veis galhas no limbo foliar (est.11, figs. 2-4). Tais estruturas, tambëm chamadas de cecídias, são alterações no padrão de cresci mento normal de tecidos e örgãos vegetais, que podem ocorrer em 
qualquer região da planta, sob a influência de organismos indutow res. Estes incluem algas, líquens, fungos, bactérias, virus, ācaros, nematóides e insetos, entre outros (FERNANDES \& MARTINS , 1985). Os insetos são os mais importantes formadores de galhas, destacando-se os dipteros e os himenópteros (FERNANDES, 1987). Mais de 93 영 gas galhas ocorrem em dicotiledôneas, sobretudo em suas fo Ihas (FERNANDES \& MARIINS, op.cit.).

O registro fóssil das galhas remonta ao Cretáceo (FERNANDES \& MARTINS, 1985). O estudo de folhas fósseis, entretan to, tem merecido pouca atenção por parte dos pesquisadores. No Brasil, até o momento, não foi realizado nenhum trabalho mais : a profundado a respeito desses fósseis, embora existam algumas refe rências na literatura (HOLLICK \& BERRY, 1924; DUARTE \& VASCONCE LOS, 1980; DUARTE \& REZENDE-MARTINS, 1985; FITTIPALDI et al., 1989; FITTIPALDI \& SIMÕES, 1990).

Na tafoflora da Formação Itaquaquecetuba, essas max cas tambëm foram encontradas em espécimes de Luehea divaricatiformis, Myrcia cf. rostrataformis e Serjania Iancifolia. Mesmo con siderando a grande abundância e complexidade de galhas em folhas atuais, parece cabivel admitix que as galhas tenham sido produzidas pela ação de insetos, visto que apresentam grande semelhança com galhas entomögenas atuais. De momento, contudo, faltam elemen tos para uma identificação mais precisa do agente indutor. Considerando, porēm, que o estado de preservação, bastante favorävel. , propicia a realização de estudos mais detalhados, existem pexspec tivas de uma identificação a nível de familia ou mesmo genërico. 
Gênero Schizolobium vogel

Schizolobium inaequilaterum Fittipaldi, Simões, Giu lietti \& Pirani, 1989.

(est. 2, fig. 3; est. 9, fig. 1)

Schizolobium inaequizaterum Fittipaldi et al. 1989, p.189, figs. 5,20; Fittipaldi \& Simões, 1989, p. 28, est. 1, fig. d.

Material - GP/3E-4763; procedência - Porto de areia no 1 da Itaquareia, Itaquaquecetuba, SP.

Descrição - Folíolo simëtrico, contorno oblongo, āpice obtuso, base sub-cordada, assimëtrica, margem inteira, pecio 10 não preservado. Padrão de nervação camptōaromo - broquidódromo; nervura mediana retilinea a ligeiramente arqueada, de calibre mo derado, diminuindo de espessura em direção ao äpice; nervuras secundārias divergem da primäria formando ângulos agudos largos a aproximadamente retos (66-850); nervuras secundārias se juntam às sobrejacentes, próximo à margem, formando arcos; venação intersecundāria inconspícua.

\section{Distribuição estratigräfica - A famĩi Caesalpinia} ceae está representada desde o cretáceo superior (CREPET \& TAYLOR, 1985). O gênero Schizozobium, no entanto, é bastante raro no estado fössil, sendo que, com excessão da espécie aqui tratada, foi assinalado apenas na Bacia de Fonseca (GORCEIX, 1876), de prová vel idade eocênica. 
Discussão - ofóssil aqui descrito corresponde certamente a schizolobium inaequilaterum, proposta por FITTIPALDI et al. (1989).

Nos detalhes da nervação e forma geral, o fóssil ë muito semelhante à espēcie atual s:parahyba, bastante comum na Mata Atlântica.

Segundo GORCEIX (1876), dentre os fósseis coletados na Bacia de Fonseca (MG), puderam ser reconhecidas folhas atribui veis a s.excelsum, as quais, contudo, não foram descritas ou figuradas.

\section{Familia FABACEAE}

Comentärios - A família Fabaceae compreende cerca de 400-500 gêneros e 10.000 (HEYWOOD, 1979) - 12.000 (CRONQUIST, 1981) espécies, distribuidos nas regiões tropicais e subtropicais. E constituída principalmente por ervas, incluindo tambēm algumas ärvoxes e arbustos (HEYWOOD, op.cit.). Seus representantes apre sentam folhas em geral trifoliadas (exceto as primārias, que são simples), com margem inteira e padrão de nervação brợuidódnomo (HICKEY \& WOLFE, 1975; JOLY, 1983).

Gênero Machaerium Persoon Machaerium piranii sp. nov.

(est.1, figs. 5,6; est. 2 ,figs. 1,2; est.12, figs.14). 
Holótipo - GP/3E-5091; localidade-tipo: Porto de areia n\& 1 da Itaquareia, Itaquaquecetuba, SP.

$$
\begin{aligned}
& \text { Parātipos }-\mathrm{GP} / 3 \mathrm{E}-5089,-5090,-5091,-5093,-5099, \\
& -5103,-5109,-5238 \mathrm{a},-5238 \mathrm{~b} .
\end{aligned}
$$

Epiteto especifico - espécie dedicada ao prof. Dr. Josē Rubens Pirani, do Departamento de Botânica do Instituto de Biociências da USP.

Diagnose especifica - Folíolo simëtrico, eliptico, āpice emarginado, base arredondada, margem inteira, peciólulo nor mal. Nervação broquidódroma; nervura primäria de calibre forte, re tilinea; nervuras secundärias moderadas, alternas ou sub-opostas, partem da primária formando ângulos agudos moderados (46-610); nex vuras terciārias reticuladas ao acaso, formanđo ângulos variāveis com as secundārias; nervuras quaternārias e quintenārias pantem de nexvuras de ordem respectivamente infexior, de acordo com àngu los variäveis; aréolas de desenvolvimento perfeito, com forma e tamanho variāveis, com vênulas ramificadas.

Descrição - Folílo simêtrico, contorno eliptico, com numerosas estruturas de contorno circular dispersas irregular mente pelo limbo, āpice emarginado, base arredondada, margem in teira, peciólulo normal. Padrão de nervação camptódromo-broquidōdromo; nervura primária de calibre forte, retilínea; nervuras se cundārias moderadas, alternas ou sub-opostas, partem da primäria formando ângulos agudos moderados $(46-61$ ) ; nervuras secundārias, ascendentes em direção ao āpice, curvam-se abruptamente próximo à 
margem unindo-se às sobrejacentes; nexvuras terciārias reticuladas ao acaso, formando ângulos variāveis com as secundárias; nervuras quaternārias e quintenārias, de espessura proporcional, partem de nervuras de ordem respectivamente inferior, de acordo com ângulos variáveis; aréolas de desenvolvimento perfeito, com forma e tama nho variáveis (pentagonais, quadrangulares, triangulares, arredon dadas, etc), com vênulas ramificadas.

Distribuição estratigráfica - Segundo DUARTE \& REZENDE-MARTINS (1983), os fósseis mais antigos de Machaerium : são encontrados no Oligoceno-Mioceno da Bolívia. No Cenozöico brasilei ro, o gênero está representado no Plioceno do Acre (BERRY,1937) e no Jazigo Vargem Grande do Sul, atribuido ao Quaternário (.DUARTE \& REZENDE-MARTINS, op.cit.).

Discussão - Apesar deste fóssil apresentar alguma semelhança com as mirtáceas, ele possui majores afinidades com as leguminosas, evocando fortemente foliolos de Fabaceae. Dentre os gêneros viventes, o que mais se assemelha é Machaerium, embora Dalbergia também possa sex considerado afim.

Em alguns espécimes (est. 1, figs. 5,6; est. 2, fig. 1; est.12, figs. $1,3,4)$, se destacam numerosas estruturas de contorno circular dispersas pelo limbo. De inicio tais estruturas, apa rentemente orgànicas, foram intexpretadas como glândulas. Conside rando, porëm, seu tamanho incompatível com glândulas que eventualmente ocorrem em representantes atuais das leguminosas (Copaifera por exemplo), sua distribuição irregular, e o fato de que, em alguns casos, elas se sobrepõem às nervuras, esta possibilidade foi 
descartada. E possivel que as mesmas correspondam a galhas provocadas por fungos ou insetos, jä que estruturas similares são frequentemente encontradas em leguminosas atuais (Machaerium nicti tans, por exemplo).

No Plioceno do Acre, ocorre M.premuticum, propos ta por BERRY (1937). M.piranii difere claramente de M.premuticum pelo fato desta apresentar formato ovado, āpice agudo e nervuras secundárias muito curvadas.

Para o Jazigo Vargem Grande do Sul, DUARTE \& REZENDE-MARTINS (1983) descreveram M. nervosum. A espécie aqui descrita difere de M.nervosum porque esta apresenta formato oblongo, äpice retuso e base obtusa. Além disto, as duas espëcies diferem sig nificativamente nos detalhes da nervação.

Ordem MYRTALES

Família MYRTACEAE

Comentārios - A família Myrtaceae é principalmente tropical e subtropical, com dois grandes centros de dispersão,nas Amēricas e na Austrälia, embora ocorra em todo o mundo (HEYwood, 1979; JOLY, 1983). E constituída por cerca de 100 gêneros e 3.000 espëcies atuais, incluindo plantas lenhosas, arbustivas ou arbó reas (JOLY, OP.cit.). Em geral as mirtáceas apresentam folhas simples, coriāceas, com margem basicamente inteira, padrão de nervação broquidödromo e numerosas glândulas sub-epidérmicas (HICKEY \& WOLFE, 1975; HEYWOOD, op.cit.). A familia possui afinidades : com 
as Lythraceae e as Melastomataceae (HEYWOOD, op.cit.).

Gênero Myroia de Candolle ex Guillarmod Myrcia cf. rostrataformis Hollick \& Berry, 1924 (est. 3, figs. 1-4; est.14, figs. 2-8).

Myreia cf. rostrataformis Hollick \& Berry, 1924,p. 91-93, est. 11, figs. 1-4; Fittipaldi et al., 1989, p.190, figs. 7a, b, 22, 23; Fittipaldi \& Simões, 1.989, p.29, est. 1, fig. f.

$$
\begin{aligned}
& \text { Material }-\mathrm{GP} / 3 \mathrm{E}-4719,-4721,-4722,-4723,-4724, \\
& -4725,-4726,-4728,-4730,-4731,-4732,-4733,-4734,-4735, \\
& -4737,-4738,-4739 a,-4739 b,-5061,-5062,-5063,-5065,-5066, \\
& -5067,-5068,-5069,-5070,-5071,-5072,-5073,-5074,-5075, \\
& -5076,-5077,-5078,-5079 a,-5079 b,-5080,-5081,-5082,-5083, \\
& -5084,-5086,-5109,-5110,-5141,-5142,-5144,-5145,-5148, \\
& -5149,-5150,-5151,-5152,-5153,-5154,-5155,-5157,-5160, \\
& -5197,-5205,-5253 a,-5253 b,-5330,-5333 a,-5333 b ; \text { procedència },
\end{aligned}
$$

Porto de areia no 1 da Itaquareia, Itaquaquecetuba, sp.

Descrição - Folha simētrica, com dimensões variando de 2,8 a $7,0 \mathrm{~cm}$ de comprimento por 0,7 a $1,4 \mathrm{~cm}$ de largura na par te preservada, contorno oblongo -- lanceolado, ligeiramente falciforme, com numerosas glândulas de tamanho reduzido, äpice agudo, ate nuado, base aguda, atenuada, margem inteira, peciolo normal. Pa drão de nervação camptódromo-broquidóaromo; nervura primāria maci ça, retilinea a ligeiramente curvada na porção distal, afilando li geiramente em direção ao ápice; nervuras secundärias, de calibre 
moderado, divergem da primária segundo ângulos agudos moderados (55-580), e se unem em arcos, junto à margem, às supra-adjacentes, numa nervura coletora, formando ângulos obtusos; nervuras secundārias alternas ou sub-opostas; nervuras terciārias reticuladas ao acaso.

\section{Distribuifão estratigräfica - o gênero Myrcia teria} aparecido no Cretäceo superior da América do Norte, segundo HOL LICK \& BERRY (1924) e é muito abundante no estado fóssil, estando representado por pelo menos 32 espëcies distribuidas do cretäceo Superior ao Pleistoceno (DUARTE, 1972). Provavelmente o nümero de espēcies fósseis é bem major, considerando a possibilidade de que muitas formas apareçam mascaradas na literatura como espécies de Eucalyptus, já que os dois gêneros se assemelham muito no aspecto falcjforme (HOLLICK \& BERRY, op.cit.). No Cenozóico brasileiro, o gênero está representado na Formação Pirabas, de idade miocênica (DUARTE, 1972), no Plioceno da Bahia (HOLLICK \& BERRY, op.cit.), e no Jazigo Vargem Grande do Sul, de suposta idade quaternāria(DUAR TE \& REZENDE-MARTINS, 1985). De acordo COM OLIVEIRA-SILVA (1983, se gundo DUARTE \& REZENDE-MARTINS, op.cit.), Myrcia também ocorre na Bacia de Fonseca, de provāvel idade eocênica. As informações refe rentes a essa ocorrência, entretanto, não estão disponíveis na li teratura.

Discussão - Este fóssil se constitui, provavelmente, na forma mais abundante e facilmente identificāvel na tafoflora da Formação Itaquaquecetuba. Foram coletados mais de 60 espécimes, in clusive alguns praticamente completos. 
A nervação broquidödroma, aliada à presença de uma evidente nervura coletora e de diminutas glândulas dispersas pelo limbo, caracteriza o fóssil como uma típica mirtácea. Dentre os re presentantes desta familia, o que mais se assemelha ao material es tudado é Myrcia rostrata, arvoreta bem ramificada, com folhas lanceoladas, de āpice longo acuminado, muito frequente na flora atual da cidade de são paulo (ROSSI, 1987). G. Barroso (informação verbal) considera este fóssil tambēm semelhante a Gomidesia cambessedeana, só conhecida através de material coletado em meados do século passado em Santa Anna, provincia do Rio de Janeiro.

Na flórula da Formação Pirabas (PA), ocorre a espé cie M.pirabensis, descrita por DUARTE (1972). A espécie da Formação Itaquaquecetuba apresenta diferenças significativas em rela ção a M.pirabensis, principalmente no que se refere ao formato,tipo de base e padrão de nervação.

Para o Jazigo Vargem Grande do Sul, DUARTE \& REZENDE-MARTINS (1985) descreveram a espëcie M.diafana. O material aqui estudado difere de M.diafana, porque esta apresenta dimensões aparentemente mais reduzidas, forma elíptica e āpice emarginado. Alēm disto, a espēcie aqui estudada apresenta ângulos de divergência das nervuras secundārias sempre agudos moderados, ao contrário de $M$. diafana, onde tais ângulos podem ser agudos largos na metade infe rior da folha.

No plioceno da Bahia, é encontrada a espécie M.ros trataformis, proposta por HOLLICK \& BERRY (1924), em seu amplo estudo sobre a flora terciāria daquele estado. Segundo os autores, 
não havia düvida que o fössil por eles estudado representava uma espécie do gênero Myrcia, visto que era "praticamente idêntico" a algumas das folhas das espécies brasileiras existentes M. rostrata DC. e M.acutata Berg. Referindo-se a trabalhos anteriores, reaIizados com material procedente dos mesmos estratos, HOLLICK \& BER RY (op.cit.) comentaram que o fóssil provavelmente representava a Myrcia sp. registrada por BONNET (1905, segundo HOLLICK \& BERRY, op.cit.), e que as formas que c.von Ettingṣhausen havia lidentificado como Amphizochia e Qualea (KRASSER, 1903, segundo HOLLICK \& BERRY, op.cit.), possivelmente se referiam ao mesmo fóssil.

Com base nas descrições e ilustrações de HolLICK \& BERRY (1924), pode-se verificax que o fóssil aqui estudado assemeIha-se a M.rostrataformis no formato lanceolado e falciforme, no tipo de margem, na textura, nas dimensões e no padrão de nervação, incluindo os ângulos de divergência das nervuras secundärias em re lação à primária. A diferença mais marcante seria o espaçamento en tre as nervuras secunaárias que é maior no fóssil da Formação Itaquaquecetuba. Tal espaçamento, entretanto, è variável no próprio material estudado por HOLLICK \& BERRY (op.cit.).

Desta forma. parece cabivel atribuir o material aqui estudado a M.rostrataformis, embora a conferir, desde que somente o exame mais detalhado do holótipo poderia confirmar esta identifi cação.

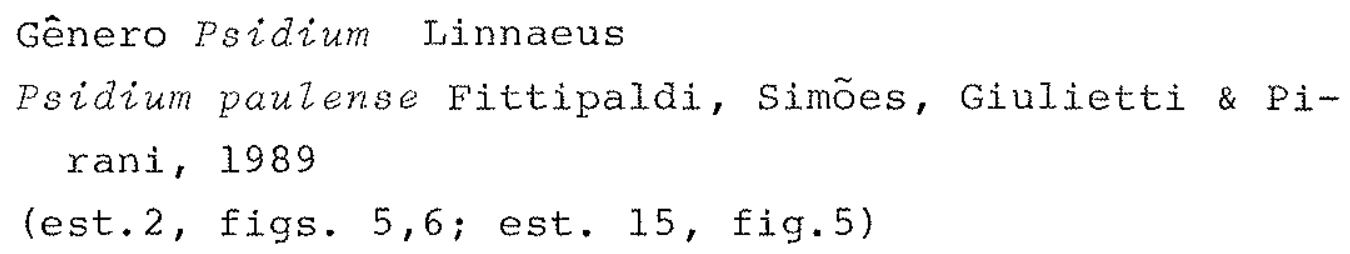


Psidium pauzense Fittipaldi et al., 1989, p.190-191, fig.8; Fittipaldi \& Simões, 1989, p.28, est.1,fig. g.

Material - GP/3E-5240; procedência - porto de areia no 1 da Itaquareia, Itaquaquecetuba, SP.

Descrição - Folha simëtrica, com $2,6 \mathrm{~cm}$ de compri mento por $2,4 \mathrm{~cm}$ de largura na parte preservada, contorno provavel mente obovado, com numerosas gländulas de contorno circular, äpice e base não preservados, margem inteira. Padrão de nervação camp tōaromo-broquidódromo; nervura primäria de calibre forte, retili nea; nervuras secundárias, alternas ou sub-opostas, divergem da primăxia formando ângulos agudos moderados a largos (53-720); nervuras secundärias moderadas, retilineas, ascendentes, curvando - se junto à margem e unindo-se às supra-adjacentes; nervuras intersecun dārias partem da primäria formando ângulos variados; nervuras terciärias reticuladas ao acaso.

\section{Distribuição estratigräfica - Psidium ē assinalado}

desde o Oligoceno superior (HOLLICK \& BERRY, 1924), embora ocorrên cias de identificação duvidosa tenham sido atribuidas a sedimen tos mais antigos. No Brasil, o gênero foi registrado na Bacia de Itaboraí, de provāvel idade paleocênica (MAGALHÃES, 1948), no Plioceno da Bahia (HOJIICK \& BERRY, op.cit.) e no Jazigo Vargem Grande do sul, considerado de idade quaternäria (DUARTE \& REZENDE-MARTINS, 1.985).

Discussão - O fóssil aqui estudado pode ser considerado uma típica mirtácea, em função da presença de nervação bro- 
quidódroma, de uma nitida nervura coletora e de numerosas glāndulas dispersas pelo limbo. Corresponde, ao que tudo indica, a Psidium paulense, descrita por FITTIPALDI et al. (1989) com base em material procedente do mesmo local.

Psidium pauzense apresenta diferenças significati vas em relação às espëcies do Psidium descritas para outros depō sitos cenozóicos brasileiros.

No Plioceno da Bahia, HOLLTCK \& BERRY (1924) descre veram P.cuneatifolium. A espēcie aqui estudada difere radicalmente de P.cuneatifolium porque esta apresenta forma marcadamente assimétrica, nervação camptódroma e ausência de nervura coletora e de glândulas. Além disto, P.paulense possui ângulos de divergência das nervuras secundárias mais abertos.

Na Bacia de Itaboraí (RJ), MAGALHÃES (1948) noti ciou a ocorrência de um fragmento de folha supostamente pertencen te ao gênero Psidium, o qual, no entanto, foi figurado mas não descrito. A má. qualidade da foto publicada por MAGALHÃES (op.cit.) inviabiliza qualquer comparação com o fóssil aqui descrito.

No Jazigo Vargem Grande do Sul (SP), ocorre a espê cie P.adornatum, proposta por DUARTE \& REZENDE-MARTINS (1985). o estado fragmentário do material de Itaquaquecetuba dificulta uma comparação mais efetiva entre as duas formas. De uma maneira ge ral, entretanto,P.paulense difere de P.adónatum porque esta apresenta forma mais assimētrica, nervura primāria mais curva e completa ausência de glândulas. 
Familia MEIASTOMATACEAE

Comentārios - A familia Melastomataceae é principalmente tropical, com alguns representantes em zonas temperadas. E uma das maiores familias de plantas da América do sul e forma uma feição particularmente caracteristica da flora brasileira. A familia é constituída principalmente por arbustos ou pequenas ärvores, mas tambëm por poucas trepadeiras, exvas, plantas de pântano e, ra ramente, epifitas. Apresenta cerca de 240 gêneros e 3.000 espécies atuais (HEYWOOD, 1979). As melastomatáceas são caracterízadas por folhas simples, margem basicamente inteira e nervuras primärias (três a nove pares) usualmente palmadas e paralelas (padrão de ner vação acrödromo) (HICKEY \& WOLFE, 1975; HEYWOOD,op.cit.).

Gênero Bertolonia Raddi
Bertolonia coimbrai sp. nov.
(est. 3, fig. 5)

Holótipo - GP/3E-5239; localidade-tipo: Porto de areia no 1 da Itaquareia, Itaquaquecetuba, SP.

Epiteto específico - espēcie dedicada ao prof. Dr. Armando Marcio Coimbra, do Instituto de Geociências da USP.

Diagnose especifica - Folha simētrica, elíptica,ba se obtusa, margem inteira. Nervação acróaroma basal de desenvolvimento perfeito; 5 nervuras primärias, incluindo a sub-marginal, de calibre fraco, partem do mesmo ponto da base da folha; nervura me- 
diana formando ângulos de 35-520; nervuras secundárias de calibre fraco divergem da mediana formando ângulos retos ou aproximadamen te retos; nervuras terciārias unem-se às secundārias supra-adja centes formando padrões $A O, A R, A A$ e RO.

Descrição - Folha simétrica com 1,6 cm de comprimen to e $0,8 \mathrm{~cm}$ de largura em sua porção preservada, contorno elipti co-largo, āpice não preservado, base obtusa, margem aparentemente inteira, pecíolo não conservado. Padrão de nervação acröaromo basal de desenvolvimento perfeito; 5 nervuras primärias, incluindo a sub-marginal, ascendentes, de calibre iraco, partem do mesmo ponto da base da folha; nervura mediana retilinea em sua porção preservada, aparentemente com calibre similar às laterais; nervuras primārias laterais divergem da mediana formando ângulos de 35-520, acompanhando o contorno da folha; nervura sub-marginal mui to próxima da margem; nervuras secundārias divergem da : mediana formando ângulos retos ou aproximadamente retos, sendo que algu mas unem-se às supra-adjacentes formando ângulos aproximadamente retos; nervuras terciārias unem-se às secundārias supra-adjacen tes formando padrões $A O, A R, A A$ e RO.

Distribuição estratigráfica - Embora a familia Melastomataceae já esteja registrada em rochas datadas do Eoceno (BERRY, 1916), esta parece ser a primeira ocorrência do gênero Bertolonia no'estado fóssil, desde que na literatura especializada não foi encontrada qualquex referência ao mesmo. Diversas 은 corrências de melastomatáceas, de outro lado, têm sido assinala das em outros depósitos cenozóicos brasileiros, de idades variando do Eoceno ao Quaternārio (HOLLICK \& BERRY, 1924; DUARTE, 1956, 1972; MEZZAILIRA, 1961-62). 
Discussão - Este fóssil ē representado por apenas um espëcime, incompleto e de pequenas dimensões. Entretanto; o padrão de nervação acrōaromo, típico das melastomatāceas, permite a inclusão dentro desta familia.

Dentre os representantes atuais da familia, o que a presenta maior afinidade com o fóssil descrito é Bertolonia mosenii que, ao contrārio da maioria das melastomatáceas, apresenta nervuras secundārias mais espaçadas.

No formato geral e pađrão de nervação, o fōssil aqui descrito apresenta grande similaxidade com B. mosenii. No espécime fóssil não foi verificada , porẻm, a presença de espinhos, que são muito Erequentes na espécie atual. Considerando, de outro lado, que tal espēcime corresponde provavelmente a uma folha jovem, com def $\underline{i}$ ciente estado de preservação, a ausência daquelas estruturas é per feitamente normal.

Ordem POLYGALALES

Familia MALPIGHIACEAE

Comentārios - A família Malpighiaceae compreende a tualmente cerca de 60 gêneros e 800 espécies de ampla distribui ção nas regiõés tropicais, especialmente na América do sul (HEYWOOD, 1979). Inclui plantas herbāceas, arbustivas, arböreas, ou, mais frequentemente, trepadeiras (JOLY, 1983). Seus representantes a presentam basicamente folhas simples, com margem inteira e padrão de nervação broquidódromo (HICKEY \& WOLFE, 1975). A famỉila tem 
sido associada às Trigoniaceae e Tremandraceae dentro da ordem Po lygalales, e com as Houmixiaceae (Geraniales) e Zygophyllaceae(sa pindales) fora desta ordem (HEYWOOD, op.cit.).

\author{
Gênero Byrsonima Richard ex Jussieu \\ Byrsonima bulzata Fittipaldi, simões, Giulietti \& \\ Pirani, 1989. \\ (est. 4, figs. 1-4; est. 15, figs. 1-4,6) \\ Byrsonima buzzata Fittipaldi et al., 1989, p.189 - \\ 190, figs.6, 21; Fittipaldi \& Simões, 1989, p.28, \\ est. 1, fig. e.
}

Material - GP/3E -5241, $-5243,-5272$; procedência Porto de areia no 1 da Itaquareia, Itaquaquecetuba, SP.

Descrição - Folha simëtrica, com dimensões variando de 2,8 a $3,7 \mathrm{~cm}$ de comprimento por 1,6 a $2,8 \mathrm{~cm}$ de largura, con torno amplamente elíptico, äpice arredondado, base obtusa, margem inteira, pecĩolo não preservado. Nervação camptóaroma - broquidódroma; nervura primäria de calibre forte, retilínea, diminuindo de espessura em direção ao āpice; nervuras secundāxias arqueadas, de calibre moderado, com ângulos de divergência agudos moderados(maio res do que $450^{\circ}$ do meio para a base e com cerca de 450 acima do meio), unindo-se às supra-adjacentes pröximo à margem, i: Eormando ângulos agudos; nervuras terciārias bem marcadas, percorrentes, principalmente sinuosas ou recurvadas, oblíquas em relação à nervura primária, com arranjo predominantemente oposto; nervuras tex 
ciärias unem-se às secundärias supramadjacentes formando padrões AR, AO e RO; nervuras quaternärias, de espessura proporcional, divergem das texciārias de acordo com ângulos predominantemente retos (padrão ortogonal).

\section{Distribuição estratigráfica - No estado fóssill,}

Byrsonima parece ser bastante raro. Com excessão de Byxsonima buz lata, não foram encontradas outras referências na literatura, embora BERRY (1916) tenha comentado a ocorrência "extremamente duvi dosa" do gênero no Plioceno da Itália. A familia Malpighiaceae, de outro lado, está representada no Plioceno da Bahia (BERRY,1935), no Plioceno do Acre (MAURY, 1937) e no Quaternärio do cearā (DUAR TE \& NOGUEIRA, 1980$)$.

Discussão - Este fóssil è morfologicamente compativel com Byrsonima bulzata, proposta por FITTIPALDI et al.(1989), com base em material procedente do mesmo local.

$\mathrm{Na}$ forma da folha, nervação, e especialmente textura, o material aqui estudado apresenta simiJaridade com algumas es pécies atuais do gênero Byrsonima.

Ordem SAPINDALES

Família SAPINDACEAE

Comentärios - A família Sapindaceae compreende cerca de 150 gêneros e 2.000 espëcies atuais, distribuídos nos trópi cos e subtrópicos de todo o mundo (HEYWOOD, 1979). A maioria das 
plantas aqui incluidas é constituỉa por trepadeiras com gavinhas, ocorrendo tambēm axbustos ou mesmo árvores (JOLY, 1983). Em ge-ral, as sapindāceas apresentam folhas compostas, basicamente pinadas, com margem denteada e padrão de nervação craspedódromo (HICKEY \& WOLFE, 1975). A família è relacionada às Aceraceae, Hippo castanaceae e Melianthaceae (HEYWOOD, 1979).

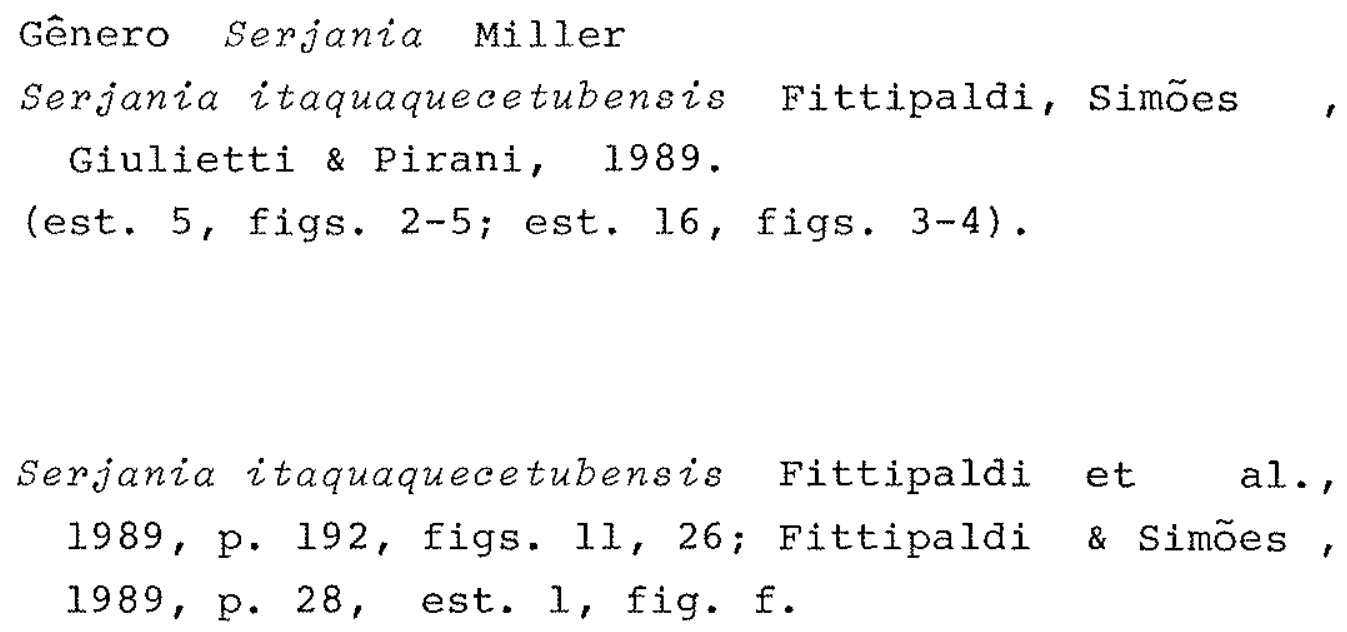

Material - GP/3E $-5236,-5238 \mathrm{a},-5238 \mathrm{~b}$; procedênciaPorto de areia no I da Itaquareia, Itaquaquecetuba, SP.

Descrição - Folíolo simétrico, com dimensões variando de 2,8 a $3,3 \mathrm{~cm}$ de comprimento por 1,2 a $1,3 \mathrm{~cm}$ de largura na parte preservada, contorno ovado, ápice agudo, base agua, mar gem irregularmente serrada com ângulos apicais agudos, pecíolo normal. Padrão de nervação craspedóaromo; nervura primäria de calibre moderado, retilinea; nervuras secundārias, alternas ou sub-opostas, divergem da primäria formando ângulos agudos moderados $(47-650)$; são nervuras espessas, retilíneas ou 
ligeiramente arqueadas, ramificando-se dicotomicamente pröximo à margem; nervuras terciārias reticuladas ao acaso.

\section{Distribuição estratigräfica - A família Sapindaceae} já é registrada no Cretáceo superior (BERRY, 1916), ao passo que os fösseis mais antigos de Serjania datam do Mioceno (BERRY,1929)). Na flora cenozöica do Brasil, o gênero è encontrado na 'Formação Pirabas, de idade miocênica (DUARTE, 1972) e no Jazigo Vargem Gran de do Sul, atribuĩdo ao Quaternārio (DUARTE \& REZENDE-MARTINS, 1983).

Discussão - Pela nervação craspedōdroma, margem irregularmente serrada, e forma geral, este fóssil é morfologicamen te compativel com a familia sapindaceae, em especial com serjania itaquaquecetubensis, descrita por FITTIPALDI et al. (1989) para o mesmo depósito.

No aspecto geral, as espëcies de Serjania descritas para outros depösitos cenozóicos brasileiros são facilmente ais :tinguíveis do material aqui estudado. S. itaquaquecetubensis difere de S.decursiva, descrita por DUARTE (1972) para a flórula da Formação Pirabas (PA), principalmente pelo tipo de margem e pa drão de nervação. S.itaquaquecetubensis distingue-se de S.mezza Zirai, proposta por DUARTE \& REZENDE-MARTINS (1983) para o Jazigo Vargem Grande do Sul, pela forma e padrão de nervação.

Finalmente, o material aqui estudado difere de $S$. Zancifolia, descrita por FITTIPALDI et al. (1989) para o mesmo local, pelo fato desta apresentar contorno lanceolado. No demais, as 
duas espécies são muito semelhantes.

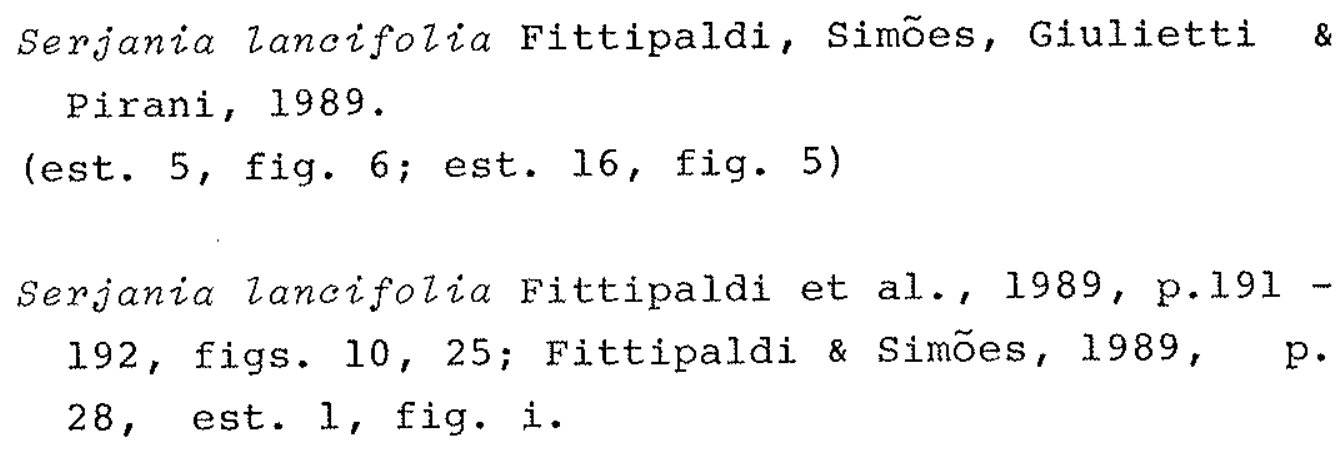

Material - GP/3E-4770; procedência - Porto de areia no 1 da Itaquareia, Itaquaquecetuba, SP.

Descrição - Folíolo simétrico, com $1,4 \mathrm{~cm}$ de compri mento por $0,4 \mathrm{~cm}$ de largura, contorno lanceolado, āpice agudo, ba se aguda, margem irregularmente serrada, com ângulos apicais agudos e lobos mais ou menos arredondados, pecíolo não preservado.Pa đrão de nervação crespedódromo; nervura primāria de calibre forte, retilinea, afilando ligeiramente em direção ao ápice; nervuras se cundārias, predominantemente opostas, divergem da primāria forman : do ângulos agudos moderados a largos (56-730); são nervuras as cendentes, de calibre moderado, retilineas ou ligeiramente arquea das, ramificando-se dicotomicamente próximo à margem; nervuras in tersecundärias densamente reticuladas.

Discussão - o padrão de nervação craspedōaromo, a margem irxegularmente serrada, e a forma lanceolada, permitem a imediata atribuição deste fóssil a serjania lancifolia, descrita por FITTIPALDI et al. (1989), com base em material procedente do mesmo local. 
Conforme visto anteriormente, s. Zancifolia difere de S.itaquaquecetubensis, proposta por FITTIPALDI et al. (1989) pa ra o mesmo depösito, principalmente por apresentar formato marcadamente lanceolado.

\author{
Subclasse ASTERIDAE \\ Ordem RUBIALES \\ Familia RUBIACEAE
}

Comentärios - A familia Rubiaceae engloba repre sentantes em todas as regiões climäticas do mundo, ocorrendo a maioria nos trópicos e subtrópicos, principalmente em matas, sava nas, cerrados e caatingas (PRADO, 1987). E uma das maiores familias de angiospermas, compreendendo cerca de 500 gênexos e aproxi madamente 7.000 espëcies atuais (JOLY, 1983). A maior parte das espécies tropicais é constituỉa por ärvores ou arbustos, enquanto que todas as temperadas são herbāceas (HEYWOOD, 1979). As rubiāceas possuem folhas simples, com margem basicamente inteira e padrão de nervação broquidōdromo; a presença de estipulas é particularmente caracteristica (HICKEY \& WOLFE, 1975; HEYWOOD, Op. cit.).

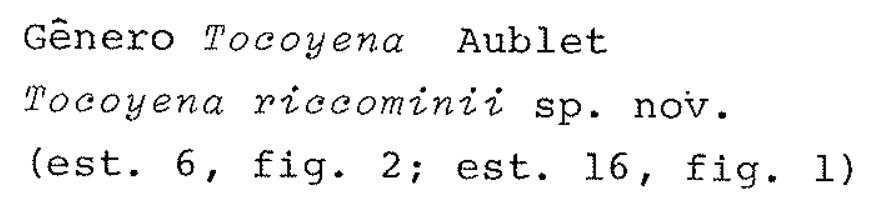

Holótipo - GP/3E-5133; localidade-tipo: Porto de areia no I da Itaquareia, Itaquaquecetuba, SP. 
Epíteto específico - espécie dedicada ao Prof. Dr. Claudio Riccomini, do Instituto de Geociências da USP.

Diagnose especifica - Folha simétrica, obovada, mar gem inteira. Nexvaçăo broquidödroma; nervura primária de calibre forte, curvada na metade superior da folha; nervuras secundārias de calibre moderado, sub-opostas, divergem da primāria segundo ân gulos agudos moderados a estreitos (42-630), unindo-se às supra-ad jacentes próximo à margem; nervuras terciárias reticuladas ao aca so; nervuras quaternārias e quintenārias divergem de nervuras de ordem respectivamente inferior, de acordo com ângulos variäveis.

Descrição - Folha simétrica, com 6,1 cm de compri mento por $5,2 \mathrm{~cm}$ de largura, contorno amplamente obovado, āpice e base não preservados, margem inteira, pecíolo não preservado. Padrão de nervação camptódromo - broquidódromo; nervura primāria de calibre forte, curvada na metade superior da folha, da qual partem nervuras secundārias de calibre moderado, formando ângulos a gudos moderados a estreitos (42-630); nervuras secundārias subopostas, unindo-se às supra-adjacentes próximo à margem; nervuras terciārias reticuladas ao acaso; nervuras quaternārias e quintenä rias, de espessura proporcional, divergem de nervuras de ordem respectivamente inferior, de acordo com ângulos variāveis.

$$
\text { Distribuição estratigräfica - Apesar da origem : đa }
$$
familia Rubiaceae remontax ao Paleoceno (IAMORTE, 1952), não foram encontradas, na literatura paleobotânica, referências Tocouena.Certamente o fössil aqui descrito se constitui na primeira ocorrência do gênero para a flora cenozóica do Brasil, embora ou- 
tras rubiāceas, jä tenham sido assinaladas anteriormente (GORCErX, 1884; BERRY, 1937; DUARTE, 1972), em depósitos com idades variando do Eoceno ao Plioceno.

Discussão - Este fössil é representando por um ünico espécime que, apesar de incompleto e não muito bem preservado,permite a observação de detalhes da nervação. Estes detalhes, bem como o formato da folha, são perfeitamente compatíveis com o gênero Tocoyena. O espëcime foi comparado com diversas espécies deste gênero, e a que mais se assemelha é T.brasiziensis, muito frequente no Estado de são paulo.

\author{
Classe LILIOPSIDA \\ Subclasse ALISMATIDAE \\ Ordem ALISMATALES \\ Família ALISMATACEAE
}

Comentärios - A familia Alismataceae se constitui nu ma pequena familia de plantas aquáticas ou anfíbias (HEYWOOD, 1979), cujos representantes são encontrados essencialmente nas regiões tropicais e na região temperada do hemisfërio norte (JOLy,1983). A familia conta com cerca de 10 gêneros, dos quais apenas dois (Sa gittaria e Echinodorus) ocorrem no Brasil. Seus representantes a presentam lâmina foliar grande, de forma muito variável, com di versas nervuras que correm, mais ou menos paralelamente, da base ao āpice onde convergem (JOLY, op.cit.). 
Gênero Echinodorus Richard ex Engelmann Echinodorus rossiae sp.nov.

(est.6, fig.1; est. 8, figs.4.5)

Holótipo - GP/3E-5152; localidade-tipo: Porto de areia no I da Itaquareia, Itaquaquecetuba, SP.

$$
\text { Parätipo - GP/3E-5163 }
$$

Epiteto específico - espécie dedicada à botânica Lu cia Rossi, do Instituto de Botānica do Estado de são Paulo.

Diagnose especifica - Folha simples, contorno possi velmente ovado, base aparentemente obtusa, margem inteira. NervaÇão campilódroma, com cerca de 17 nervuras primárias, de calibre fraco, divergindo de um mesmo ponto da base; nervuras secundärias muito finas, mais ou menos paralelas, unindo as primārias, forman do ângulos retos ou aproximadamente retos.

Descrição - Fragmento de folha simples, $\operatorname{com} 2,3 \mathrm{~cm}$ de comprimento por $1,5 \mathrm{~cm}$ de largura na parte preservada, contor no provavelmente ovado, āpice não preservado, base aparentemente obtusa, margem inteira. Padrão de nervação provavelmente campilódromo, com cerca de 17 nervuras primárias de calibre fraco divergindo de um mesmo ponto da base da folha; nervuras secundárias mui to finas, mais ou menos paralelas, unindo as primárias, formando ângulos retos ou aproximadamente retos. 
tânica não foram encontradas referências ao gênero Echinodorus. o fóssil aqui descrito se constitui, desta forma, no primeiro regis tro do gênero, bem como da familia Alismataceae, para a flora cenozóica do Brasil, embora fragmentos de plantas aquáticas da Formação Rio claro tenham sido atribuIdos, com aūvidas, a esta família, por BJORNBERG et al. (1964).

Discussão - Este fóssil é representado por numerosos fragmentos, embora apenas dois apresentem dimensões superio res a $2 \mathrm{~cm}$, possivelmente devido à fragilidade da folha.

Os pequenos fragmentos podem ser eventualmente confundidos com restos de folhas de palmeiras ou plantas afins. En tretanto, nos espëcimes maiores e melhor preservados, o padrão de nervação campilódromo e a disposição das nervuras secundārias, sü gerem fortemente tratar-se de uma típica folha de Alismataceae.

Dentre os gêneros da família representados atualmen te no Brasil, o que mais se assemelha ē Echinodorus.

\subsubsection{SEMEN"NES}

$$
\begin{aligned}
& \text { Material }-\mathrm{GP} / 3 \mathrm{~T}-1826 ;-1830,-1831 \\
& \text { (est. 6, figs. 4,5; est. 17, figs. 1,6) }
\end{aligned}
$$

Procedência - Porto de areia no 1 da Itaquareia, Itaquaquecetuba, SP. 
de comprimento, de cor escura e testa (?) Iisa; em corte longitudinal aparece a testa (?) e o tégmen (?), este último bem desenvol vido, e um lóculo, correspondente provavelmente à localização do embrião.

Discussão - As estruturas analisadas foram consideradas como proväveis sementes, especialmente pela presença de um tégmen (?) espesso e que deixa uma pequena linha de abertura : na porção distal, podendo corresponder à região da fusão dos tegumentos do óvulo e canal micropilar. Estes fósseis são especialmente a bundantes na camada fossilifera centimëtrica (foto 3), onde ocor rem associados com restos de folhas e de pequenos caules. Ao con trāxio das folhas, que estão reduzidas a fragmentos de diminutas di mensões, estas sementes estão geralmente intactas e pouco deformadas.

A variação morfológica observada dentre estas estru turas é relativamente pequena, sendo possível que, em sua quase to talidade, as mesmas possam ser atribuidas a um ünico taxon.

Embora a variabilidade da estrutura da semente das angiospermas e sua relativa constância em grupos menores permitam utilizar os seus caracteres na classificação de plantas (ESAU,1974), as dificuldades que envolvem sua identificação taxonômica são muito grandes, principalmente no que se refere a espécimes fósseis.

Conforme destaca MCCLURE (1957), a identificação de sementes desconhecidas é difícil e frequlentemente impraticāvel, já que não existem tratamentos organizados comparáveis com manuais bo 
tânicos, nos quais a planta pode ser determinada. As poucas chaves de classificação existentes, utilizando características de semen tes, referem-se a um número reduzido de famîlías.

Usualmente, a unica maneira de identificar sementes desconhecidas é através da comparação com ilustrações da literatura especializada ou com material de herbärio. Entretanto, a lite ratura referente a estudos taxonômicos de sementes a nível de famí lia è muito escassa. Nos compêndios de taxonomia, poucos representantes de cada familia têm sementes figuradas ou descritas em maior detalhe. Na literatura paleobotânica, por sua vez, existem poucos trabalhos especificamente voltados a sementes de angiospermas fósseis. No Brasil, apenas MAGALHÃES (1950) e BEURLEN \& SOMMER (1954) estudaram sementes cenozöicas em maior profundidade, sendo que a maioria dos autores tem se limitado a simples referências à presen Ça de tais fósseis (PAULA COUTO, 1949; ALMEIDA et al., 1984; MANDA RIM-DE-LACERDA, 1985; 1986). Além da escassez da literatura espe cializada, cumpre ressaltar o fato de que faltam espēcimes moder nos para comparação, jā que nem todas as plantas de herbário incluem frutos ou sementes.

Considerando o acima exposto, bem como o fato da classificação das sementes ser baseada principalmente em aspectos não preservados no documentärio paleontológico, é preferível,conforme jâ admitido por FITTIPALDI et al. (1989), não atribui-las a um taxon em especial, visto que, de momento, não existem elementos que permitam uma atribuição segura. 


\subsubsection{FRUIIOS}

Familia FABACEAE

Gênero Sophora Linnaeus

Sophora giuliettiae sp. nov. (est. 13, figs. 1-3)

Holótipo - GP/3E-5218; localidade-tipo: Porto de areia no 1 da Itaquareia, Itaquaquecetuba, SP.

Epíteto específico - espēcie dedicada à Profa.Dra. Ana Maria Giulietti, do Departamento de Botânica do Instituto de Biociências da USP.

Diagnose especifica - Fruto indeiscente, pleios pérmico, com constrição na região entre as sementes, formando seg mentos globosos, continuos entre si ou separados por regiões in tercalares.

Descrição - Fruto indeiscente, provavelmente ci Iíndrico e de superficie lisa, pleiospërmico, com constrição na região entre as sementes, formando segmentos globosos de $1 \mathrm{~cm}$ de comprimento por $0,8 \mathrm{~cm}$ de largura, continuos entre si ou separa dos por regiões intercalares com cerca de $0,1 \mathrm{~cm}$ de comprimento por $0,3 \mathrm{~cm}$ de largura.

Distribuição estratigräfica - Os fósseis mais anti gos de Sophora datam do Paleoceno (KNOWLTON, 1917), referindo-se quase que exclusivamente a folhas. O fóssil aqui descrito se cons titui no primeiro registro do gênero, bem como na primeira ocor - 
rência de um fruto moniliforme, para o cenozóico brasileiro.

Discussão - Este fóssil é representado por um ūni co espécime, infelizmente fragmentado após a coleta, em função do ressecamento da matriz. Entretanto, apesar de incompleto, o fós sil pode ser identificado como um fruto moniliforme, típico das leguminosas, e em especial do gênero sophora.

\subsubsection{FHADTOS（？）}

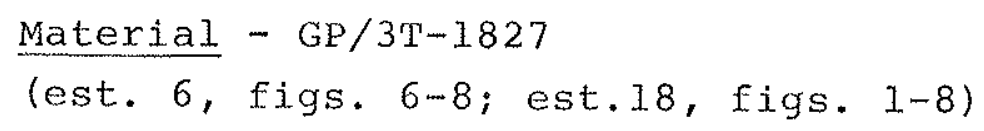

Descricão - Em vista frontal, estes fósseis apre sentam-se como estruturas triangulares, portando dois "sacos" de cada lado. Em corte longitudinal cada "saco" corresponde a pelo menos dois lóculos internos, que são revestidos por uma película de tecido mais claro e reticulado.

Discussão - Uma anālise preliminar destas estruturas em vista frontal, lembrou de imediato um megasporófilo de Gymnospermae com dois óvulos. Porēm, um exame mais detalhado mos trou a presença de dois "sacos" laterais, e um corte Iongitudinal mostrou a presença de värios lóculos. E possivel que este material pertença às dicotiledôneas, embora aparentemente não mostre afinidade com qualquer das familias atuais.

Observação: alëm das sementes e frutos anteriormente tratados, foram encontradas prováveis estruturas reprodutivas (est. 19, figs. 1-6), de difícil identificação taxonômica. 


\section{COMPARACAO COM RESTOS VEGETHAIS ASSINALADOS RMU OUTHROS DEPOSITOS CENOZOICOS DO RSTADO DE SÃO PAULO.}

Os vegetais fósseis assinalados nos megaclastos da Formação Itaquaquecetuba apresentam pequena utilidade, pelo menos a nîvel genérico, em correlações temporais, visto que, devido à sua grande distribuição ao longo do Cenozöico, não são diagnósti cos do ponto de vista cronológico.

Considerando que a posição relativa da ocorrência fossilffera aqui estudada, bem como de todas as demais referentes a restos vegetais dentro da sequência sedimentar cenozóica, ainda não foram avaliadas, fica difícil antever qualquer possibilidade de datação. Existem perspectivas, entretanto, de que esta possibilidade venha a se concretizar após o estudo de um grande número de formas, procedentes de distintos níveis estratigräficos, dos vārios depósitos desta e de outras bacias cenozóicas. Vários depó sitos, inclusive, têm fornecido coleções substanciais, as quais, no entanto, ainda não estão adequadamente estudadas.

Assim sendo, estudos mais abrangentes, procurando mostrar as possiveis afinidades dos restos vegetais da Formação I taquaquecetuba com os de outros depösitos cenozóicos apresentam

grande potencialidade. Isto é especialmente verdadeiro no caso do Cenozóico do estado de são Paulo, onde numerosas ocorrências têm sido assinaladas, embora poucas tenham sido estudadas atē o momen to. (figura 7 ) 


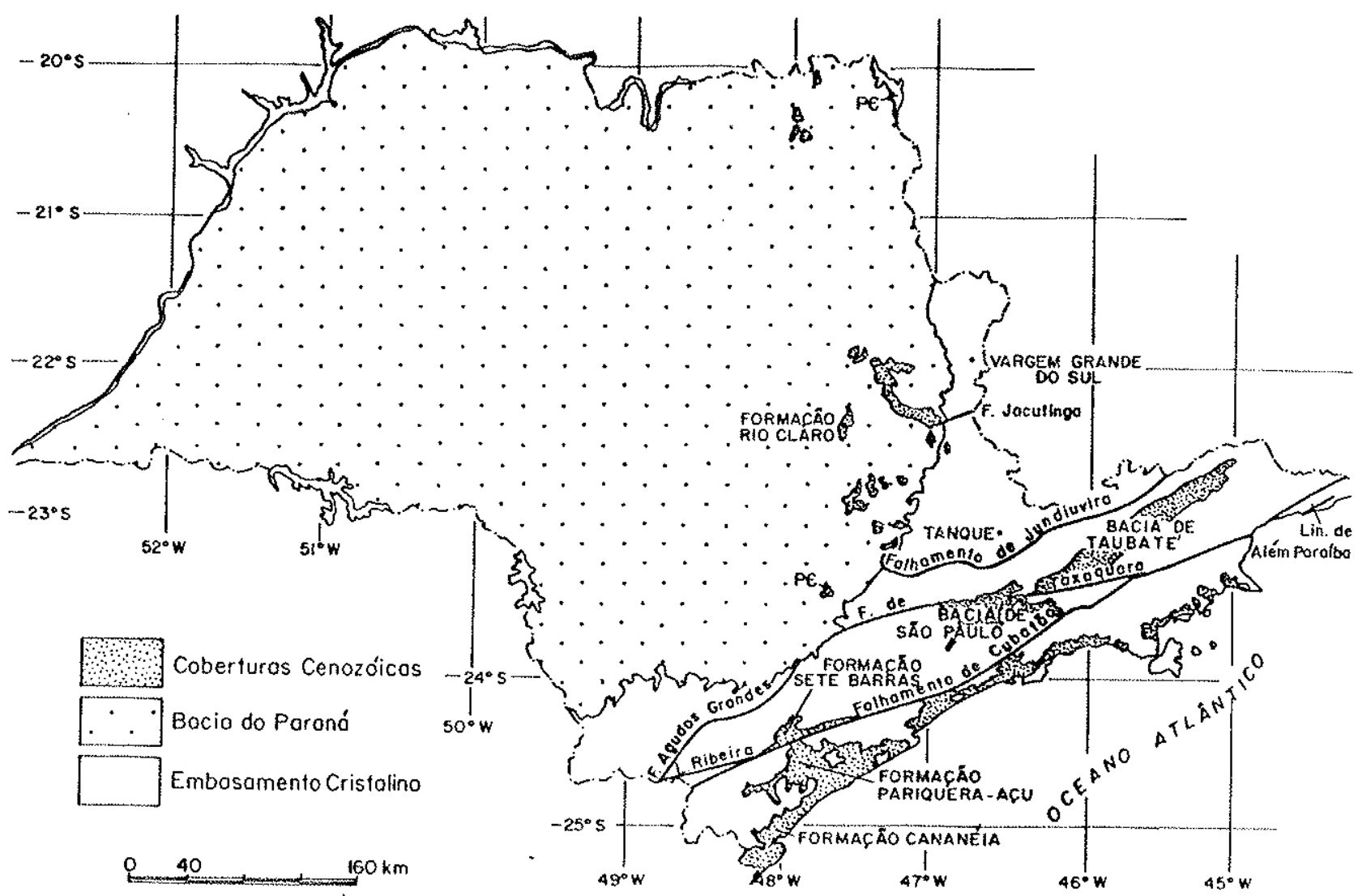

Figura 7 - Principais ocorrências de sedimentos cenozóicos no es tado de são paulo e suas relações com as grandes feições tectôni cas (modificado de ALMEIDA et al., 1981). 
Com base em material obtido em trabalhos de campo, e em informações disponíveis na literatura, uma breve anālise com parativa é feita a seguir, visando fornecer subsidios para trabathos futuros, quando o conhecimento a respeito dessas ocorrências estiver mais avançado.

\subsection{BACTA DE MABBATE}

\subsubsection{FORMAÇÃo TREMEMBE}

A Formação Tremembé, proposta por ALMEIDA (1957), consiste na unidade estratjgräfica basal da Bacia de Taubaté. Com preende uma sequência sedimentar gerada em um complexo lacustrino, com alteração das condições de predominio de lagos para predomí nio de riosu(HASUI et al. 1978). Litologicamente, a formação é ca racterizada pelos folhelhos papiráceos, pirobetuminosos, e argili tos silticos maciços, contendo intercalações de areias e argilas (MEZZALIRA \& PAULA COUTO, 1971 ).

Estudos palinológicos efetuados em amostras de tes temunhos de um poço que, segundo LIMA et al. (1985a), corresponde à parte superior da unidade, forneceram uma provāvel idade oligocênica. O material palinologicamente fértil, entretanto, foi obti do apenas na porção superior da parte testemunhada.

Em função de uma facies lacustre bem estabelecida, seu documentário paleontolögico e bastante rico, sendo constituido por abundantes restos animais e vegetais. Sua paleoictiofauna, 
em especial, hä muito tem atraĩdo a atenção dos pesquisadores (Rㅡ GONHA, 1982). Os megarestos vegetais, entretanto, apesar de assinalados desde o início do século, ainda são relativamente pouco estudados.

Deve-se a MANDARIM-DE-LACERDA (1985, segundo DUARTE \& MANDARIM-DE-LACERDA, 1987), o primeiro estudo sobre : esses restos, com base em material procedente de dois sitios fossiliferos localizados nos arredores da cidade de Tremembé: Mina Nossa Senhora da Guia e Fazenda Santa Fé. A coleção estudada era com posta por 7 folhas, 2 frutos e uma semente. Infelizmente, : este estudo permanece inédito, de modo que seus resultados não estão disponiveis na literatura.

Posteriormente, MADARIM-DE-LACERDA et al. (1986) a presentaram uma nota curta a respeito do estudo biométrico, morfo lögico e taxonômico da tafaflora proveniente do Jazigo Mina Nossa Senhora da Guia. Os restos vegetais estavam representados por 6 folhas, 2 frutos e uma semente, bem como por palinomorfos pertencentes a diferentes grupos (fungos, pteridófitas, coniferas e dicotiledôneas).

O trabalho mais recente sobre os restos vegetais da Formação Tremembé è o de DUARTE \& MANDARIM-DE-LACERDA (1987). As autoras identificaram preliminarmente, ao nível supra-genërico apenas, no Jazigo Fazenda Santa Fé, uma tafoflora representada por restos de carófitas, pteridófitas, gimnospermas, "l dicotilledôneas (Lauraceae, Nymphaeaceae, Guttiferae, Mimosaceae, Caesalpiniaceae, Falaceae, Myrtaceae, Celastraceae, Rutaceae, Loganiaceae e Apocy- 
naceae) e monocotiledôneas (Graminae e Typhaceae). A associação, se gundo as autoras, indicaria um clima subtropical úmido, contrapon do-se à informação de LIMA et al. (1985a), que sugeriram um clima frio e seco.

Considerando que, com base em espécies de palinomor fos estratigraficamente importantes (LIMA et al., 1985a; IIMA \& ME LO, 1989), parece haver alguma contemporaneidade entre a sedimenta ção da parte superior da Formação Tremenbé e a dos níveis orgâni cos (megaclastos) da Formação Itaquaquecetuba, seria até certo pon to admissivel a ocorrência, nestas unidades, de algumas formas comuns. Entretanto, desde que ainda não existem informações disponiveis a respeito dos gêneros e espécies presentes na Formação Tre membé, fica difícil o estabelecimento de eventuais correlações, embora pelo menos 5 familias (Lauraceae, Mimosaceae, Rutaceae, Myrtaceae e Caesalpinaceae) estejam presentes em ambas unidades.

\subsubsection{SEDTMENTOS SOBREJACENTES A FORMAÇÃO TREMEMBE}

A Formação Pindamonhangaba, proposta por RICCOMINI (1989), mas ainda não. formalizada, constitui, em parte, os depōsi tos anteriormente denominados Formação Caçapava.

E constituída por sedimentos essencialmente $\therefore$ fú viais meandrantes (RICCOMINI, 1989). Sua idade provavelmente cor responde ao Terciärio superior.

Ao contrário da Formação Tremembë, estratigrafica - 
mente inferior, seu documentário paleontológico é bastante escasso. Os ünicos registros na literatura, até o momento, referem-se a restos mal preservados de peixes originalmente descritos em sedimentos referidos à Formação Caçapava (VICALVI, 1982). Restam dū vidas, entretanto, sobre a posição estratigräfica desses fósseis (C. Riccomini, informação verbal).

Recentes trabalhos de campo têm demonstrado, de ou tro lado, a ocorrência de níveis que, embora pouco espessos, são muito fossiliferos. Dois jazigos merecem destaque:

a. Afloramento PB-33 (RICCOMINI, 1989) - : siltuado no município de Taubaté, próximo ao $\mathrm{km} 1,6$ da $\mathrm{sp}-123$ (rodovia Qui ririm - Campos de Jordão), a $250 \mathrm{~m}$ da saIda para Campos de Jordão, junto ao cruzamento das ruas 29 e Antonio da Silva, no extremo nordeste da Folha Taubaté III, SF-23-Y-D-11-2-NO-D, 1:10.000, Pla no Cartográfico do Estado de São Paulo, Projeto Macroeixo.

Neste afloramento pode ser observado um nível de argila avermelhada, extremamente rico em restos vegetais. : Estes são constituidos basicamente por fragmentos de caules e de folhas, dispostos de maneira caótica.

Os caules estão representados por fragmentos bas tante reduzidos, sendo de identificação taxonômica provavelmente impossivel, visto que ocorrem na forma de moldes desprovidos de feições diagnósticas.

As folhas, por sua vez, são geralmente de pequenas 
dimensões, embora fragmentos de até $7 \mathrm{~cm}$ de comprimento tenham si do observados. Alguns espécimes encontram-se praticamente completos e em razoável estado de preservação. Em muitos casos, porém, - padrão de nervação está indistinto, dificultando a correta iden tificação.

Um exame preliminar dessas folhas revelou a presen ça, com relativa abundância, de típicas folhas de melastomatāceas e de folhas alongadas com nervação paralelinérvia, provavelmente pertencentes às gramíneas ou monocotiledôneas afins. Foi $\because$ também verificada a presença de algumas folhas que, segundo J.R. Pirani (informação verbal) assemelham-se muito às de Anacardium, embora com dimensões mais reduzidas.

b. Afloramento TB-25 (RICCOMINI, 1989) - situado no km 124,5 da BR-116 (Rodovia Presidente Dutra), no sentido São Paulo - Rio de Janeiro.

Neste corte, correspondente à mesma posição estratigräfica do $T B-33$, foi tambëm constatada a presença de um nível fossilifero, embora menos rico. Existem informações a respeito de fósseis muito bem preservados neste afloramento. No entanto, foram obtidos apenas restos que, em função de sua natureza fragmentäria, e do seu precário estado de preservação, não possibilitam maiores considerações de carāter taxonômico.

De momento, seria prematura qualquer comparação com a tatoflora da Formação Itaquaquecetuba, visto que os vegetais da Formação Pindamonhangaba ainda são conhecidos de forma muito pre- 
liminar. Com base no material disponivel, contudo, parece cabivel afirmax que, no aspecto taxonômico, a única semelhança ocorre a nivel de familia, visto que as melastomatäceas ocorrem nas duas unidades. De outro lado, parece haver uma presença expressiva,na Formação Pindamonhangaba, de monocotidedôneas, ao contráxio do que ocorre na Formação Itaquaquecetuba onde, atē agora, apenas um espēcime foi registrado. Finalmente, ao que tudo indica, as dimen sões das folhas são bem mais reduzidas no caso da Formação Pindamonhangaba, embora tal fato possa er devido a fatores tafonômioos.

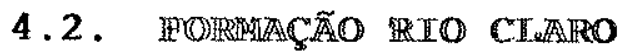

A Formação Rio Claro foi definida por BJoRNBERG \& LANDIM (1966) a partir de estudos efetuados na ärea entre os rios Piracicaba e Pardo, sendo constituida por sedimentos predominante mente areníticos, por vezes conglomeráticos, com lâminas e leitos de argila subordinados. Seus depósitos assentam-se, em grande par te, sobre as formações Pirambóia e Estrada Nova (OKA-FIORI,1987).

Hā divergência quanto à distribuição desta unidade. Alguns autores admitem que a distribuição da unidade seja mais am pla do que aquela apontada originalmente. PONÇANo (198I) limita - uso da designação à área em que foi originalmente definiaa, sem deixar de assinalar como correlatos, no Mapa Geológico do Estado de São Paulo, depósitos assim mencionados pela literatura.

Assim como outros depósitos cenozóicos de origem continental, a idade da Formação Rio Claro ainda não está bem es- 
tabelecida. FÚlfaro \& SUGUjo (1968) consideram-na neocenozöica. M. R. Lima (informação verbal), com base palinológica, propõe uma ida de pleistocênica.

Atë o momento, os megafösseis conhecidos na Formação Rio Claro referem-se exclusivamente a vegetais aquáticos. Es ses restos foram objeto apenas de um estudo preliminar de BJORNBERG et al. (1964) e atribuídos, com düvidas, ās familias Nymphaeaceae, Potamogetonaceae e Alismataceae.

A família Alismataceae está representada na Formação Itaquaquecetuba atravēs do gênero Echinodorus. A descrição sumária do material estudado por BJORNBERG et al. (1964), entretanto, đifficulta qualquer comparą̧ão.

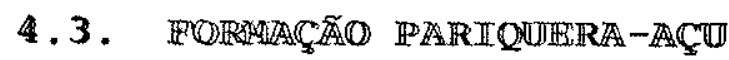

A Formação Pariquera-Açu, definida por BIGARELLA \& MOUSINHO (1965), corresponde aos depósitos em terraços do baixo vale do Rio Ribejra de Iguape e de seu afluente, o Rio Jacupiranga.

A unidade é composta predominantemente por sedimen tos finos, com alternâncias irregulares de siltitos arenosos e a renitos arcosianos, associados a camadas conglomexäticas pouco es pessas (BIGARELI.A \& MOUSINHO, 1965). O mecanismo de deposição foi principalmente do tipo movimento de massa, que teria ocorrido sob condições de paleoclima semi-ärido (RICCOMINI et al., 1987). 
A Formação constitui o substrato para a Formação Cạ nanéia, do pleistoceno superior, e outros depósitos costeiros do Quaternārio, sendo considerada de idade (mínima) pliocênica-pleistocênica segundo dados palinológicos preliminares (RICCOMINI et al., 1987).

MARCEILO (1981) assinalou, em nota prévia, a ocor rência de restos vegetais (folhas e caules) em sedimentos atribuidos à Formação Pariquera-Açu, na região de Iguape, sem no entanto apresentar qualquer descrição ou ilustração.

Com vistas à coleta de material, foi efetuado … um trabalho de campo na localidade citada por MARCELIo (1981), mais precisamente no $\mathrm{km} \mathrm{5,7}$ da Rodovia Biguā-Iguape. Não foi encontrado, entretanto, qualquer vestígio dos vegetais citados.

\subsection{FORPACÃO CANANEIA}

A Formação Cananéia, proposta por PETRI \& isuguIo (1973), é constituida por areias finas inconsolidadas, muito bem selecionadas, com raras intercalações argilosas, depositadas em ambientes marinhos. Sua ārea de afloramento típica encontra-se na região de Iguape e Cananéia mas, segundo FÜLFARO \& SUGUIO (1974), ocorrem depósitos correlacionāveis em toda a costa SE brasileira.

Com base na cronologia proposta por SUGUIO \& MARTIN (1978) e MARTIN et al. (1979), a Formação Cananēia tem sido atribuida a um episódio transgressivo datado de cerca de 120.000 
anos AP. Hä alguma controvërsia, contudo, a respeito do caräter desse episódio.

Nos sedimentos arenosos da formação são relativamen te comuns tubos fósseis de Cazlichirus que, ao lado de raros : e mal preservados moldes internos de lamelibrânquios (sUGUTo \& MARTIN, 1976), constituem os ünicos fósseis registrados na literatura.

Em coletas realizadas na seção-tipo da unidade, no município de Cananéia, foram encontrados pequenos fragmentos vegetais, de dimensões centimëtricas, nos mesmos niveis dos tubos de Callichimus. Tais fragmentos, provavelmente correspondentes a cau les, apresentam uma insipiente carbonificação, podendo se consti tuir no primeiro registro de restos vegetais na Formação Cananéia. Essa descoberta, entretanto, deve ser encarada com as devidas re servas, considerando que o referido material pode corresponder a raizes de plantas atuais. Datações por C-14 poderão certamente con firmar a natureza fóssil desses fragmentos.

\subsection{DEPOSTTOS ISOLADOS}

Numerosas ocorrências de restos vegetais têm sido reportadas em depósitos aluviais prê-atuais, que vem sendo assinalados ao longo das principais drenagens do Planalto Atlântico (MEZ ZALIRA, 1948, 1959, 1961-62; ALMEIDA, 1952; WOHLERS et a1.,1954; WOHLERS, I964; PENALVA, 1971; COLTRINARI et a1., 1984; FULFARO et al., 1985). Tais depósitos ocorrem principalmente ao Iongo dos rios Paraibuna, Paraitinga, Parateí, Tietê, Jundiaí, Atibaia e Ja- 
guari, sendo que nem sempre a correlação com a drenagem atual ẽ e vidente, encontrando-sealçadas de mais de 10 metros em relação ao leito atual (MELO \& PONÇANO, 1983).

A idade desses depósitos é incerta, de modo "que têm sido considerados ora terciārios, correlacionáveis às :Bacias de são Paulo e Taubaté, ora quaternärios, sincrônicos às glaciais. Segundo PONÇANO (1981), a maior parte dessas ocorrências é quater nāria, correspondendo a pexĩodos de formação de terraços e pedi mentos, sincronicamente às glaciais.

Esses restos, em sua quase totalidade, ainda não foram objeto de estudos sistemāticos. As ocorrências melhor conhe cj̃das são abordadas a seguir.

\subsubsection{TANQUE}

A unidade sedimentar informalmente denominada "Tan que" por Fútraro et al., (1985) aflora junto à Rodovia Fernão Dias, pröximo à antiga estação ferroviāria do Tanque, nas imediações de Atibaia. A unidade é constituía por sedimentos arenosos, com estratificação cruzada, e siltico-argilosos, com : estratificação plano-paralela, não raro, tão finamente laminada que torna-se um folhelho (FÜLFARO et al., op.cit.). Nos sedimentos argilosos são encontrados abundantes restos vegetais e estruturas de escavação de animais perfuradores (FÜLFARo et al., op.cit.). Esses restos são representados por folhas, caules: e esporos, frequentemente carbonificados. Até o momento, somente proväveis restos de carófi 
tas foram identificados (WOHLERS et al., 1954).

Embora essa unidade já tenha sido referida por di versas vezes na literatura (ALMEIDA, 1952; WOHLERS et al., 1954 ; PENALVA, 1971; FÜLFARO et al., 1985), nunca foi apresentada qual quer descrição mais detalhada ou ilustração dos restos vegetais. De acordo com V.J.Fūlfaro (informação verbal), os restos vegetais são muito abundantes e bem preservados. PENALVA (op.cit.) tambëm se refere à "boa qualidade de parte do material", solicitando a aju da de especialistas para "identificar pelo menos as familias ou or dens presentes". Segundo F.Penalva (informação verbal), as folhas se assemelham muito às da vegetação arbórea atual, não se referindo, provavelmente, a restos de vegetais aquáticos.

Considerando, portanto, que não existem informações disponíveis na literatura, somente coletas minuciosas poderão fornecer maiores detalhes a respeito desses fósseis e de suas possí veis relações com os de outros depósitos cenozóicos. Estudos palinolögjcos, de outro lado, poderão fornecer subsíaios para o estabe lecimento da idade desses sedimentos.

\subsubsection{JAZIGO VARGGHMA GRRINDE DO SUIL}

O Jazigo Vargem Grande do Sul, assinalado inicial mente por MEZZALIRA (1961-62), é constituido por argilas caulini cas muito ricas em impressões vegetais.

o jazigo acha-se situado no município de vargem 
Grande do sul, no sitio Cachoeira, a $4 \mathrm{~km}$ ao sul da cidadeide Var gem Grande do sul, na margem direita do Ribeirão Cachoeira, afluente da margem direita do Rio Jaguari (MEZZALIRA, 1961-62). Segun do A.M.Coimbra (informação verbal) esse depósito pode ser considerado como correlato à Formação Rio Claro.

MEZZALIRA (1961-62) descreveu a nova espécie t'ibou china izizdaisabelae (Melastomataceae), referindo-se ainda à presença de folhas atribuidas às familias Anonaceae e às ordens Ebenales e Rutales.

Posteriormente, DUARTE \& REZENDE-MARTINS (1983) e fetuaram um estudo mais detalhado no jazigo. Além de formas jä assinaladas em outros depósitos cenozóicos, como sapinaus ferrei rai (Sapindaceae da Bacia Miocênica de Pirabas) e Platypodium potosianum (Leguminosae do Plioceno de Cerro de Potosi, Bolívia), as autoras verificaram a presença de 8 novas espécies de dicotiledôneas: Cassia parkerii, C. elliptica, c.parabicapsularis (Legumi nosae - Caesalpinioaceae, Machaerium nervosum, Camptosema cordatum, C.primum (Leguminosae - Fabaceae..), Cedrela arcuata (Meliaceae) e Serjania mezzalirai (Sapindaceae).

DUARTE \& REZENDE-MARTINS (1983) atribuiram esse depósíto ao Quaternärio, embora sem apresentar qualquer argumento a favor desta idade.

Um estudo complementar a respeito do jazigo foi apresentado por DUARTE \& REZENDE-MARTINS (1985), no qual : foram descritos 8 novos taxons de dicotiledôneas: Maytenus fragizis (ce 
lastraceae), Eugenia vargensis, E.punctata, Psidium adornatum, My $\underline{r}$ cia diafana, Calyptranthes argizosa, Gomidezia costata (Myrtaceae) e Symplocos dealbata (Symplocaceae). Foi tambēm verificada a pre sença de Tibouchina izildaisabezae, descrita anteriormente por MEZZALIRA (1961-1962).

Pelo menos cinco gêneros reconhecidos no: Jazigo Vargem Granđe do sul também foram assinalados na Formação itaqua quecetuba, ou seja, Cassia, Serjania, Psidium, Myroia e Machae rium. Alëm disto, a família Melastomaceae tambëm estä representada nos dois casos.

Apesar da ocorrência de gêneros comuns às duas tafo floras, os fósseis, contudo, são marcadamente distintos a nível es pecifico.

\subsubsection{DEPOSTTOS DE VARZEAS DO PARATEI}

Dentre as numerosas ocorrências isoladas de depósitos aluviais pré-atuais, destaca-se a värzea do Rio paratei, cons tituida por argilas e areias. Segundo COLTRINARI et al (1984), ao longo do vale do rio são frequentemente encontradas camadas conten do restos vegetais, que incluem troncos de até $60 \mathrm{~cm}$ de diâmetro, folhas e fragmentos de galhos.

De acordo com COLTRINARI et al. (1984), esses res tos, sobretudo troncos e fragmentos de galhos, acham-se notavelmen te bem preservados. Os troncos foram atribuỉos aos gêneros Aspi dosperma (Apocynaceae), Nectandra (Lauraceae), Ficus (Moraceae), 
Tabebuia (Bignoniaceae) e Cedrela (Meliaceae) (TTTARELLI,1975, segundo COLTRINARI et al., 1984 ).

Datações com C-14, efetuadas em amostras extraĩas de duas sequências de depósitos orgānicos, inãicaram, para a infe rior, uma idade de 7.700 anos AP e, para a superior, 1700-2200 a nos AP (COLTRINARI et al., 1984).

Das familias identificadas na värzea do Rlo Para teî, apenas Lauraceae estä representada na Formação Itaquaquecetú ba, através do gênero ocotea. Folhas de cedreza, de outro lado, foram assinaladas por DUARTE \& REZENDE-MARTINS (1983) no Jazigo Vargem Grande do sul. 


\section{PALEOCLIMA}

\subsection{PALEOCLIMA DA FORMAÇÃo TMAQUAQUECETUBA}

A determinação do paleoclima da Formação Itaquaque cetuba é de grande importância para o entendimento da revolução palleogeográfica do sudeste brasileiro no cenozóico, sem perder de vista, naturalmente, as implicações de ordem global.

$\mathrm{Na}$ literatura geolögica brasileira existe, pelo me nos, uma dezena de trabalhos que abordam o problema do paleoclima daquela formação. Nesses estudos, o paleoclima tem sido inferido com base em indicadores de natureza paleontológica, sedimentológi ca, estratigräfica e geomorfológica, sugerindo desde um clima tem perado até semi-ärido.

Do ponto de vista paleobotânico, os principais indicadores utilizados na interpretação do paleoclima da Formação I taquaquecetuba dizem respeito aos troncos (SUGUIO, 1971; SUGUIO \& MUSSA, 1978; ARAI, 1987), folhas (FITTIPAIDI et al., 1989) e pali nomorfos (LIMA \& MELO, 1989). Troncos e folhas têm sugerido principalmente um clima tropical, ao passo que os palinomorfos apon tam para um clima temperado. Haveria, portanto, uma aparente contradição entre os dados forneciaos pelos macrofósseis (folhas) e 
microfósseis (palinomorfos), inclusive aqueles provenientes dos mesmos niveis orgânicos.

Para explicar esta contradição, FITTIPALDI \& SI MŐES (1989) propuseram um modelo paleoclimático (detalhado na par te final deste trabalho) baseado na zonação altitudinal de vegeta ção, cujos principais aspectos são abordados a seguir.

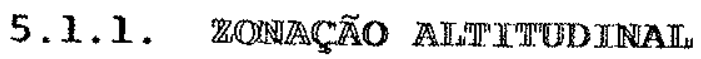

Nas regiões tropicais, as modificações climāticas que ocorrem com o aumento da altitude envolvem uma diferenciação na vegetação. Desta forma, à medida em que aumenta a altitude,a vegetação usualmente vai diminuindo em porte e se tornando mais aberta, com o desaparecimento dos estratos intermediärios. As 1ianas tornam-se raras, enquanto que o epifitismo, sobretudo o de liquens e musgos, aumenta consideravelmente.

Gradativamente vai ocorrendo um declínio na diversidade, de modo que a dominância, que è exercida a princípio por vārias espécies, qualquer que seja o status dinâmico da comunida de, passa a ser exercida por poucas espécies, ou mesmo por uma ūnica.

Em altitudes variäveis de acordo com a região considerada, a floresta perenifólia, que caracteriza os andares mais inferiores, è substituída por uma vegetação não florestal, frequen temente dominada por formas idênticas ou que lembram muito aque - 
las de regiões temperadas (GOOD, 1964). Essa vegetação é extremamente variável, sendo em geral herbácea, na qual as gramineas dominam em maior ou menor extensão.

A zonação altitudinal ë, em alguns casos, bem defi nida. Freqtentemente, porém, é difícil de ser precisada, devido à grande amplitude de variação de certas formas, que acarreta uma superposição das zonas. Assim sendo, qualquer limite entre as zonas deve ser considerado arbitrário, e uma zona deve ser encarada apenas como uma área de alta probabilidade para a ocorrência de um tipo particular de vegetação.

Embora ajnda faltem alguns elementos comprobató rios, há um consenso gexal de que o controle primärio da zonação altitudinal è a temperatura. SEGADAS-VIANNA (1965), porēm, lembra que a fisiografia, quando favorável, permite a máxima : expressão da vegetação de acordo com as possibilidades climáticas e, quando desfavorävel, causa värios graus de inibição. Desta forma, a pene tração de um andar de vegetação dentro de outro ë gexalmente de terminada e controlada por topografia.

Descrições de zonações altitudinais são escassas na literatura referente às regiões tropicais. No Brasil, a zona ção que tem sido mais intensivamente estudada é provavelmente a do Maciço de Itatiaia, que foi detalhadamente descrita por SEGA DAS-VIANNA (1965). Considerando três elementos básicos, isto è, ve getação, fisiografia e clima, este autor delimitou seis princi pais andares de vegetação: 


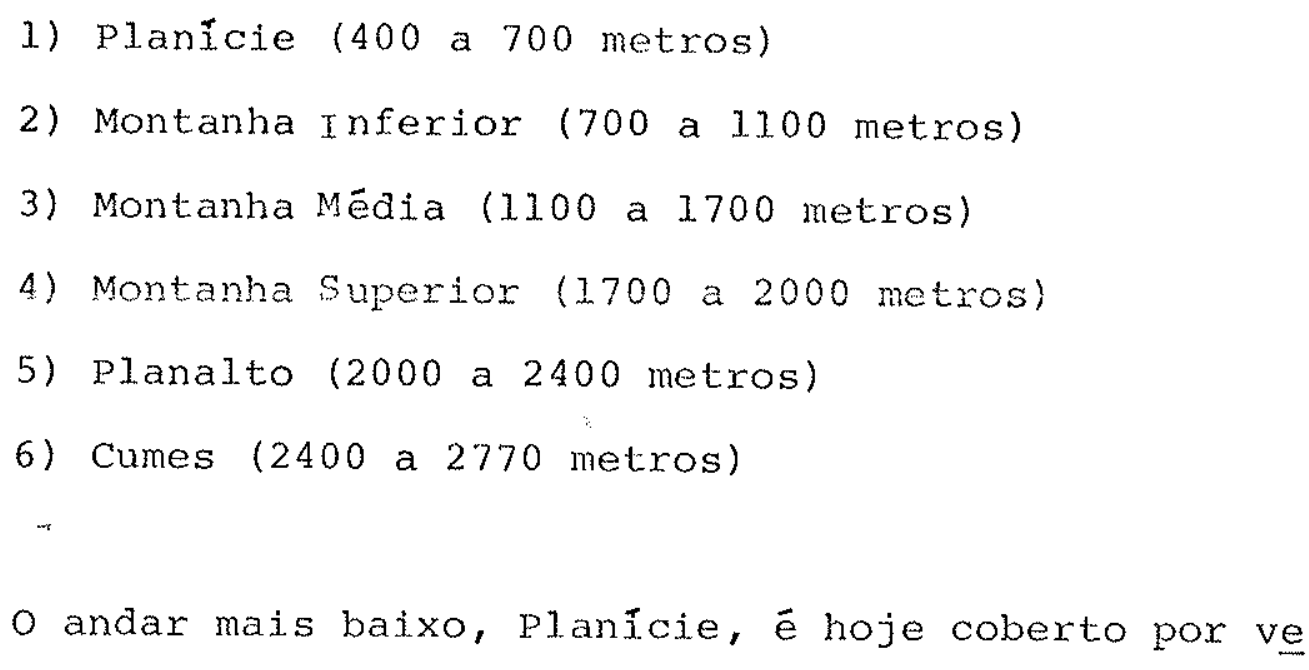
getação secundäria em seus estägios pioneiros. Sua parte superior e ocupada por uma floresta sub-climax, de 15 a 20 metros de altura, dominada por Tibouchina estrezzensis (Melastomataceae) e Cassia multijuga (Caesalpiniaceae).

O segundo andar, Montanha Inferior, è quase total mente recoberto por matas secundārias, sendo as mais comuns as dominadas por Tibouchina estrelzensis, Cassia multijuga, Miconia candolzeana e Miconia selzowiana (Melastomataceae). O climax é uma floresta aberta, de sub-bosque pouco denso, com um porte de 30 a 40 metros, constituida por árvores de troncos grossos, retili neos e raízes tabulares. A dominância é exexcida por caxiniana ex celsa (Lecythidaceae), Cedrella fissilis (Meliaceae), Cabralea eichteriana (Meliaceae) e Calzichlamis Zatifolia (Bignoniaceae).

Os andares Montanha Média e Montanha Superior têm por climax, respectivamente, uma floresta de 20 a 30 metros de altura, dominada por espécies do gênero cabralea, e uma filoresta pouco densa, baixa, com não mais de 15 metros de altura, dominada por Cabratea eichleriana. 
O penúltimo andar, planalto, de topografia irregular e bastante variada, tem por climax uma vegetaçăo graminóide com estrutura de estepe. Os três tipos de mata que ocorrem neste andar, sempre em situações topográficas especiais, matas de Roupa la Zucens (Proteaceae), de Araucaria angustifolia (Araucariaceae) e de Podocarpus lambertii (Podocarpaceae), são relíquias das vegetações climax que ocuparam a região em épocas passadas.

No ültimo andar, Cumes, a vegetação predominante é uma comunidade dominada por um bambú anão, chusquea pinifolia (Graminae), cujos indivỉduos têm um porte que não ultrapassa um metro. Esta comunidade é sem düvida alguma o climax, ainda que seja o climax edáfico. Cumpre lembrar que, nestas altitudes mais elevadas, em Eunção da escassez de chuvas, a presença de vegeta ção xerofitica é comum.

A zonação altitudinal nos Andes colombianos foi tratada de maneira bastante didática por FLENLEY (1979), que delimitou pelo menos seis andares: Floresta Inferior, Floresta subAndiña, Floresta Andina, Sub-pāramo, páramo e super pāramo (fig.

8 ). Embora o exemplo se refira a uma região equatorial, a điferenciação altitudinal na vegetação é similax à observada nos trópicos.

\subsection{INFERENCTAS PALEOCLTMATTCAS}

Conforme destacam FITTIPALDI \& ROSLER (1987), as plantas fósseis estão entre os mais fidedignos indicadores paleo- 


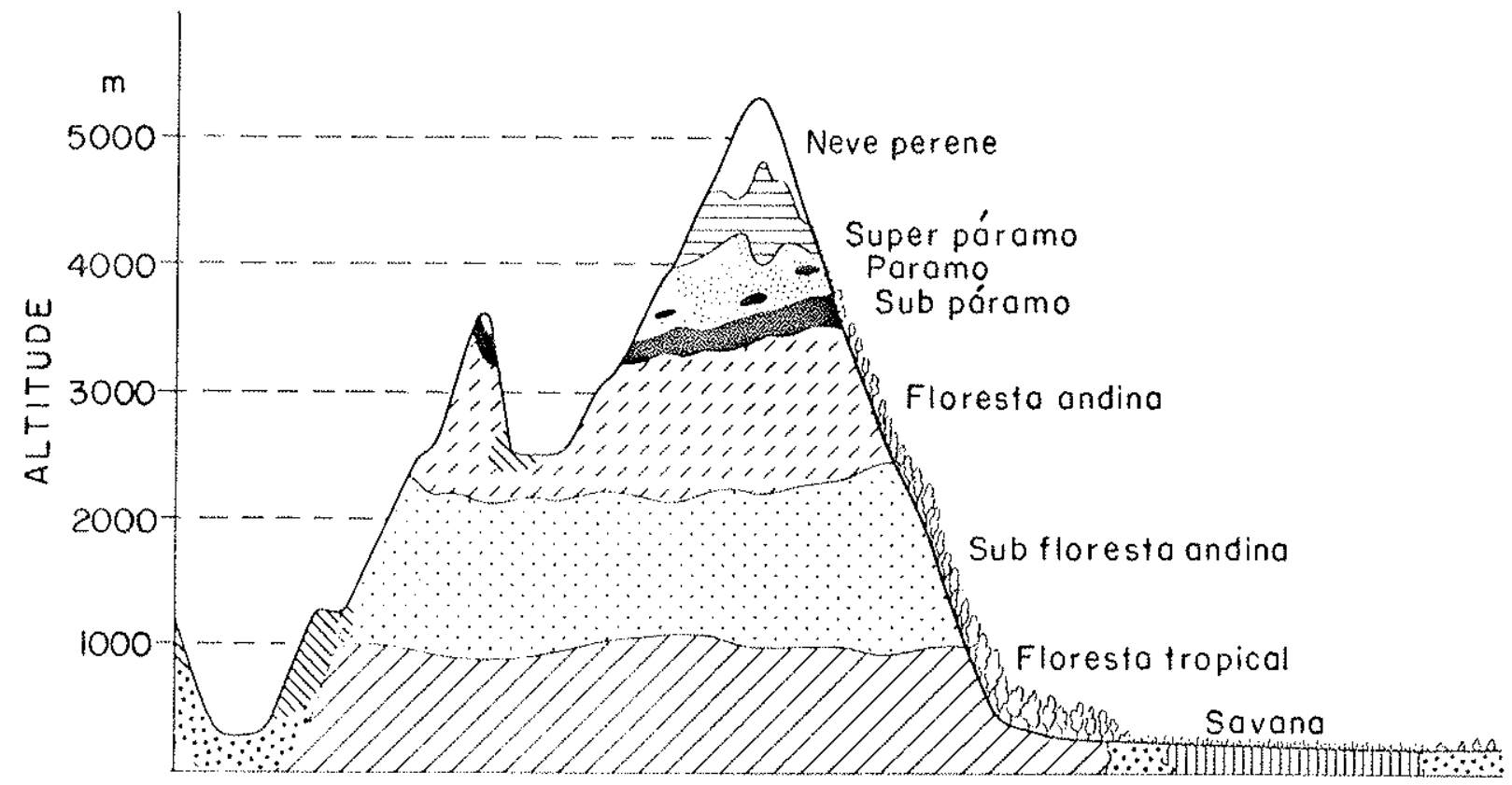

Pigura 8 - Zonação altitudinal na Cordilheira dos Andes (modificado de FLENLEY, 1979). 
cljmäticos, já que os vegetais apresentam sempre uma sensibilidade a variações ambientais de certa magnitude.

No caso da Formação Itaquaquecetuba, as folhas fōsseis apresentam especial interesse, considerando que representam $\underline{e}$ lementos adicionais para o esclarecimento do paleoclima vigente à época de deposição daquela unidade. Entretanto, para se demonstrar a validade em inferências paleoclimáticas dessas folhas, cabe aqui uma breve discussão.

Considerando a proporção relativamente alta de folhas inteixas ou pouco fragmentadas nos níveis orgânicos da Formação Itaquaquecetuba, é admissível supor que as mesmas não se depositaram muito longe da ärea fonte. Segundo MAC GINITIE (1969), foIhas de árvores crescendo a 1000 metros de um rio não podem alcanÇar o sitio de deposição, exceto durante tempestades. De outro lado, folhas de textura fina são eliminadas após poucos $\mathrm{km}$ de transporte (MAC GINITIE, op.cit.). Desta forma, podemos admitir que as folhas fornecem uma informação paleoclimätica bastante precisa,con siderando que elas representam uma vegetação que ocupava uma ārea próxima do sittio de deposição. A nível local, portanto, as folhas possibilitam inferências paleoclimäticas mais fidedignas que outros fósseis como, por exemplo, os palinomorfos, desde que estes podem ser transportados a enormes distâncias (milhares de quilometros, segundo 'BIRKS \& BIRKS, 1980) e fornecem informações de âmbi to mais regional. Alëm disto, as folhas se constituem em partes do vegetal outrora vivente e não apenas em um estágio reprodutivo do ciclo da vida (ROBERTS, 1989). As vantagens dos macrofósseis ve getais sobre os palinomorfos em reconstituições paleoambientais fo ram sumarizadas por BIRKS \& BIRKS (op.cit.). 
Conforme visto anteriormente, a quase totalidade dos fósseis presentes na Formação Itaquaquecetuba representa gêne ros presentes na flora atual. Em alguns casos, mesmo a nivel espe cífico, os fósseis são extremamente semelhantes a formas atuais (Ocotea, Luehea e Myrcia, por exemplo). Desta forma, com base nos anälogos modernos, são possíveis inferências paleoclimáticas bastante precisas.

Apesar da presença de alguns fósseis não identificáveis, a tafoflora da Formação Itaquaquecetuba apresenta uma diversidade relativamente alta, inclusive com a presença de formas (briófitas, por exemplo) que produzem quantidades muito pequenas de esporos, dispersos de maneira ineficiente, ou muito frägeis e não fossilizäveis, ou ainda não distinguíveis. Considerando que quanto maior o nümero de elementos, mais fidedigna é a reconsti tuição paleoflorística, tal fato representa uma grande vantagem em inferências paleoclimāticas.

Finalmente, cabe ressaltar que, apesar das vanta :gens das folhas como indicadores paleoclimäticos, torna-se impres cindivel uma integração com os dados palinológicos de modo a se obter um quadro paleoecológico mais completo da vegetação primitiva.

Com base no acima exposto, ë perfeitamente cabivel uma reconstituição paleoclimätica fundamentada nos vegetais fós seis, embora devam ser evitadas interpretações muito simplistas, considerando que sempre existem fatores desconhecidos agindo du rante a deposição dos fósseis e durante sua fossilização. 


\subsection{TNDHCADOIRES PAIEOCIUTMETICOS}

\subsubsection{ARQUITETURA FOLIAR}

FITIPALDI \& ROSLER (1987) lembram que as plantas não são apenas adaptadas Eisiologicamente a seu ambiente, mas tambëm desenvolvem feições anatômicas ou morfolōgicas caracteristi cas de seu habitat. As feições foliares das angiospermas, em especial, são muito afetadas pelas condições climäticas. Portanto, as condições climáticas do passado podem ser determinadas, também,por meio da arquitetura foliar. O uso da arquitetura foliar para a interpretação de paleoclimas ë baseado no princípio de que a varia ção na forma da folha é continua ao longo de gradientes climäticos, e estatisticamente correlacionada com uma ou mais variáveis climá ticas. Deste modo, o ambiente tende a selecionar plantas que têm certo aspecto físico para um dado tipo climático, quer este domine sobre áreas separadas por oceanos ou, presumivelmente, por grandes períodos de tempo.

Segundo WOLFE (1971, 1981), o uso da anguitetura foliar fornece uma das bases mais sōlidas para a avaliação do significado paleoclimätico das plantas fósseis. Wolse (1978) salienta que há värias vantagens em basear interpretações paleoclimāticas nos aspectos físicos das assembléias de folhas fósseis. As caracteristicas Eísicas de vegetações ocupando climas similares em regiões muito separadas mostram alto grau de similaridade, embora es tas regiões possam apresentar poucos taxons em comum. De outro la- 
do, vegetações submetidas a climas diferentes em uma mesma região apresentam tipicamente caracteristicas físicas diferentes, embora possam ter muitos taxons em comum. Desta forma, esta metodologia se constitui em importante ferramenta para inferir direção e magnitude de mudanças climäticas em uma sequência estratigráfica de assemblëias, particularmente se seqtências de diferentes paleola titudes são analisadas (WOLFE \& UPCHURCH, 1987). Alëm disto, o uso das feições físicas propicia inferências paleoclimāticas, independente da identificação dos gêneros e familias representados, e independente de suas distribuições climäticas atuais

(WOLFE, 1971).

Neobotânicos interessados na relação entre ambiente e arquitetura foliar também têm reconhecido a importância do uso da arquitetura foliar em inferências paleoclimáticas. De acor do com RICHARDS (1952), conclusões sobre os climas de floras terciārias são talvez mais solidamente fundamentadas quando elas são obtidas a partir dos caracteres foliares, do que quando elas se baseiam nas afinidades taxonômicas da flora fóssil.

De acordo com DOLPH \& DILCHER (1979), oito feições da arquitetura foliar podem ser correlacionadas com clima: tama nho, tipo de margem, tipo de āpice, organização (folha composta $x$ folha simples), padrão de nervação, densidade de nervação, textura e tipo de base.

No presente trabalho, para as inferências paleocli máticas, serão utilizadas somente as feições que os diversos auto res têm estudado mais intensivamente. 


\subsubsection{Tamanho}

RAUNKIAER (1934) verificou que o tamanho da folha era claramente correlacionado com umidade disponível. Desta forma, a partir desse estudo, passou a se aceitar que o tamanho da fo lha decresce continuamente ao longo de gradientes ambientais que refletem decréscimo de temperatura e/ou precipitação. Folhas gran des são encontradas em áreas tropicais úmidas, com a área foliar diminuindo em direção às montanhas ou aos polos. Estudos recentes têm corroborado estas premissas.

RAUNKIAER (1934), considerando a inerente variabilidade das folhas na mesma planta, dividiu a área foliar, numa se quência geométrica, em 6 classes:

Leptófilo - até $0,25 \mathrm{~cm}^{2}$
Nanófilo - $0,25 \mathrm{~cm}^{2}-2,25 \mathrm{~cm}^{2}$
Micrófilo - $2,25 \mathrm{~cm}^{2}-20,25 \mathrm{~cm}^{2}$
Mesófilo - $20,25 \mathrm{~cm}^{2}-182,25 \mathrm{~cm}^{2}$
Macrófilo - $182,25 \mathrm{~cm}^{2}-1640 \mathrm{~cm}^{2}$
Megafilo - acima de $1640,25 \mathrm{~cm}^{2}$

WOLFE \& UPCHURCH (1987) discutem acuradamente o tamanho da folha como indicador paleoclimático. Segundo estes au tores, modelos' matemáticos indicam que o diâmetro foliar é omcom ponente mais fortemente ligado ao ambiente físico. Considerando, portanto, que o diâmetro tem uma correlação geral com o tamanho da folha, este último é uma feição válida para interpretar vegetạ ção fóssil. O tamanho da folha é determinado por fatores tais co- 
mo disponibilidade de nutrientes, disponibilidade de ăgua, niveis de calor e niveis de iluminação, e envolve intercâmbio adaptativo entre pressões seletivas conflitantes (por exemplo, a necessidade de maximizar ganhos fotossintëticos versus a necessidade de minimizar perda d’āgua). Na vegetação moderna, as folhas maiores são encontradas em estratos inferiores de floresta de copa fechada, multiestratificadas, megatermais (temperatura mëdia anual maior do que 209C); os principais fatores operantes são iprovavelmente alta temperatura, alta umidade e ausência de iluminação solar direta. O tamanho da folha decresce em vegetações de regiões ümidas a meio umidas, mesotermais (139-209C) e microtemais (menor que 13\%C). Decréscimo de umidade disponível durante a estação de cres cimento também afeta fortemente o tamanho da folna. Em climas sub -úmidos, megatermais, o tamanho da folha é marcadamente menor do que em climas ümidos e meio úmidos, megatermais, e um fenômeno si milar relacionado à umidade ocorre em climas mesotermais e microtermais.

Embora o tamanho da folha seja um importante crité rio em estudos de vegetações atuais, a aplicação deste parâmetro a assemblëias fósseis è altamente problemätica, porque folhas de diferentes tamanhos podem ser selecionadas diferencialmente no processo de transporte e preservação (SPICER, 1975, segundo WOLFE, 1978). Alëm disto, conforme ressaltam FITTIPALDI \& ROSLER (1987), mudanças no tamanho da folha podem estar relacionadas a outros pa râmetros ambientais. DOLPH \& DILCHER (1980a, 1980b), por exemplo, analisando floras da Costa Rica e de diversas localidades do He misfërio Ocidental, verificaram que a variação do tamanho da folha ao longo de gradientes climäticos não é continua. 
Dentre os gêneros identificados na Formação Ttaqua quecetuba, há um nitido predomínio de folhas micrófilas ( tabela 1). Entretanto, vale a pena ressaltar o grande nümero de prováveis laurāceas, não passĩveis de identificação genërica, que podem ser atribuídas ao tipo mesófilo. Cabe salientar, conforme acima expos to, que fatores tafonômicos podem ter selecionado folhas de detex minados tamanhos.

Segundo RICHARDS (1952), ocorre predominio de fo thas mesófilas em florestas pluviais. De acordo com o esquema de RAUNKIAER (1934), portanto, a presença de grande nümero de fothas micrófilas, aliada à ocorrência de folhas mesófilas, poderia sugerir, com as devidas reservas, um clima relativamente úmido.

\subsubsection{Tiñpo de tuargem}

A correlação entre tipo de margem foliar e : clima foi postulada inicialmente por BAYLEY \& SINNOTT (1915): à medida que a temperatura decresce, tanto com o aumento da altitude como da latitude, a porcentagem de.espëcies tendo folhas com margens li sas tambëm decresce. Em florestas tropicais ümidas, por exemplo,a porcentagem de espécies com margens lisas é maior que 75\% (WolfE, 1969). Esta porcentagem decresce em direção às montanhas (57-75\%, para as florestias de montanha e sub-montanha) ou em direção aos polos (inferior a $39 \%$ na floresta temperada quente) (WOLFE, op. cit.). As ūnicas excessões ocorrem em āreas secas, tais como de sertos, onde a porcentagem de espécies tendo folhas com margens lisas é sempre alta, independente da posição altitudinal ou lati- 
tudinal. Estudos recentes, envolvendo floras modernas e Eösseis, têm consubstanciado estas premissas.

o uso desta feição em estudos paleoclimäticos é bas tante atrativo, porque o tipo de margem é facilmente codificado, mesmo quando se usa material fóssil fragmentārio. Entretanto, segundo WOLFE \& UPCHURCH (1987), a validade da utilização da margem da folha em estudos de temperatura è baseada nos princípios ! de que: 1) a assembléia representa uma vegetação climax; 2) a escala maxgem da folha/temperatura usada seja välida. Vegetação de habi tats perturbados (particularmente nas maxgens de rios) pode fornecex baixas estimativas de temperatura devido à alta proporção de espécies com folhas denteadas, já que estas espécies normalmente se concentram nas margens de rios ou lagos. Entretanto, na vegetação regional, a vegetação climax é mais diversa do que a vegetação per turbada e, deste modo, à medida em que a vegetação climax aumenta em uma assembléia fóssil (isto é, a amostragem da vegetação regional é mais completa), mais válida pode ser a temperatura estimada. Um corolário é que assembléias de depósitos de canal fornecerão as estimativas de temperatura menos seguras:assembléias de depōsitos lacustrinos também contém alta representação de vegetação perturba da de margem de rios (SPICER, 1981, segundo WOLFE \& UPCHURCH, 1987). Assembléias de depósitos de barras ou de depósitos que representam represamentos dentro de uma floresta tendem a produzir as estimati vas de temperaturas mais fidedignas.

Na tafoflora da Formação Itaquaquecetuba, incluindo formas virtualmente não identificáveis, apenas 4 gêneros apresen tam margens serradas ou denteadas, isto é Aquifoliphyzzum, Casea - 
ria, Serjania e Luehea (tabela 1). Predominam, portanto; as fo lhas com margens inteiras, que representam pelo menos $2 / 3$ dos gêneros identificados.

Apesar das ponderações acima apresentadas, existe de fato um significado adaptativo da margem foliar em relação ao clima, o que leva a sugerir que a associação aqui estudada possa ser indicativa de uma mata tropical ümida.

\subsubsection{Tipo de ápice}

o tipo de ápice das folhas está claramente relacio nado ao ambiente. Folhas dos estratos inferiores das florestas ū midas têm āpices atenuados, muitos dos quais são alongados em "pontas gotejantes". Apices atenuados são tipicamente ausentes em folhas de árvores da cobertura ou emergentes; algumas árvores da cobertura têm folhas emarginadas, uma condição resultante do baixo suprimento de umidade ao desenvolvimento da folha. Folhas em climas sub-ümidos têm, em muitos casos, āpices arredondados a emarginados; leguminosas e arbustos, em vegetações sub-ümidas, a presentam particularmente tal morfologia. Apices emarginados são tipicamente raros em florestas úmidas, mas são comuns em vegeta Ção seca, esclerófila )WOLFE \& UPCHURCH, 1987).

Na tafoflora estudada, o tipo de āpice é relativa mente variado, quando se consideram os diferentes gêneros. Tipi cos äpices atenuados ocorrem apenas em Monstera e Myrcia. Apices obtusos ou arredondados são comuns, podendo ser observados em 
gêneros como Schizolobium, Byrsonima e Zanthoxylum. Appices agu dos ocorrem em Serjania e Cassia. A presença de āpice emarginado, de outro lado, foi constatada apenas no gênero Machaexium. Algu mas formas não apresentam o āpice preservado, mas, a julgar pelos equivalentes atuais, não apresentariam äpices emarginados.

Hä, portanto, um claro pxedominio de äpices atenuados, agudos, arredondados e obtusos, comuns em climas ümidos ou sub-ümidos. Apices emarginados, sugestivos de climas mais secos, são bem menos freqtientes. Estes ūltimos, entretanto, embora sejam tĩpicos de vegetação esclerófila, não são exclusivos de climas se$\cos$.

Com base no acima exposto, pode-se supor que a tafo flora estudada seja indicativa de uma mata de clima úmido.

\subsubsection{Textuma}

A textura da folha tambëm pode oferecer inferências paleoclimáticas significativas, visto que a mesma está ligada ao hábito desse órgão que, por sua vez, apresenta conotações alimāticas.

Folhas perenes são tipicamente espessas e coriáceas, ocorrendo principalmente em regiões de alta temperatura e alta pre cipitação média anual (florestas tropicais e sub-ṭropicais), en quanto que as decíduas são tipicamente delgadas, ocorrendo com maior freqlência nas regiões frias ou secas (WOHE \& UPCHURCH, 1987). 
De acordo com wolfE \& UPCHURCH (1987), o häbito de cîduo parece relacionado a três fatores principais. Em plantas de crescimento rápido de vegetação sucessional de habitats perturbados, as folhas são produzidas e descartadas rapidamente, embora em geral de forma gradativa; tais plantas devem ser consideradas como continuamente decíduas. Em äreas que têm pronunciados perĩodos secos ou frios, mas têm abundante precipitação na estação de crescimento, o hābito decíduo é dominante; tais plantas são perio dicamente decíduas. Um tercejro fator ambiental periódico, a luz, pode também levar ao häbito decíduo, embora este fator seja ope rante, atualmente, apenas em uma ärea limitada.

No caso das folhas fósseis, obviamente, é muito di ficil determinar a textura com segurança. Algumas evidências, po rém, podem ser dadas pela espessura da película carbonosa resul tante do processo de carbonificação. E caso, por exemplo, de Byrsonima e Myrcia, cujos fósseis estão invariavelmente asso ciados a uma película carbonosa bastante espessa, o que poderia sugerir uma textura mais coriācea. De um modo geral, entretanto, a textura de uma folha fóssil pode ser inferida apenas com base em seu equivalente atual.

Uma anälise do material da tafoflora da Formação I taquaquecetuba, sugere o predomínio de uma textura mais espessa, embora não necessariamente coriācea. Possivelmente predominam folhas cartäceas. Tal predomínio, entretanto, pode ser devido a fatores tafonômicos, já que as folhas de textura fina podem ter sido eliminadas durante o transporte. De outro lado, a proporção re lativamente alta de folhas inteiras, aliada à presença de fósseis 
delicados como briófitas e pteridófitas, poderia indicar uma depo sição não muito longe da ärea fonte.

Desta forma, com as devidas reservas, pode-se afir mar que a tafoflora da Formação Itaquaquecetuba é indicativa de uma mata tropical ou sub-tropical.

\subsubsection{NUTERO DE ESPECTES}

O número de espécies numa comunidade vegetal é fun ção da temperatura ambiente. As zonas tropicais se destacam por um elevado número de espécies, ao passo que nas altas latitudes o nümero de espécies é muito inferior. RIGBY (1971), por exemplo, representou didaticamente a relação entre temperatura, nümero de espëcies e nümero de espēcimes por espëcie, mostrando que, à medi da que se caminha para regiões mais frias, há um decréscimo no nū mero de espëcies presentes e um acrēscimo no nümero de espēcimes de cađa espëcie presente.

Desta forma, a ocorrência de uma tafoflora muito rica em espécies, sobretudo de formas arborescentes, pode ser a tribuida a um clima mais quente.

No caso da tafoflora da Formação Itaquaquecetuba,o nümero de espécies pode ser considerado relativamente elevado,vis to que foram identificadas pelo menos 19 espécies de angiosper mas pextencentes a 14 familias diferentes. Além disto, deve ser levado em conta o fato de que as espécies descritas não correspon 
dem à totalidade das formas presentes na tafoflora, visto que algu mas não foram incluídas no presente estudo porque seu estado de preservação (padrão de nervação não preservado) não propiciava uma identificação segura.

O nümero de espécies, bem como a diversidade de gru彑 pos presentes na tafoflora (briōfitas, pteriđṓfitas, monocotiledôneas e dicotiledôneas), sugere, portanto, uma mata tropical.

\subsection{DISTRTHUICYÃO GEOGRAPICA ATUAL DOS GENEROS AS- SINALADOS NA TAFOFLORA DA FORMACÃO ITAQUAQUHCEE TURA}

Lindsaea Dryander ex Smith

Lindsaea se constitui num gênero pantropial e extratropical, com cerca de 150 espēcies, das quais 45 na América (TRYON \& TRYON, 1982). Ocorre principalmente em florestas ümidas, porēm algumas espēcies tambēm crescem em campos de gramineas, brejos, ou em āreas rochosas abertas (TRYON \& TRYON, op.cit.).

Isotachis Mitt.

Isotachis è um gênero tropical, muito comum na Mata Atlântica (o.Yano, informação verbal).

ocotea Aublet

Ocotea apresenta cerca de 200 espécies distribuí das principalmente pela América tropical e sub-tropjcal (MABBERLEY, 
1987). Se constitui numa planta lenhosa arbórea muito frequente nas matas brasileiras (JOLY, 1983). Ocotea pulchelza, que apresen ta grande afinidade com o fóssil descrito, é uma espécie comum na Mata Atlântica, podendo inclusive alcançar o cerrado (RIZZINI , 1979).

\section{Luehea willdenow}

o gênero Luehea engloba cerca de 20 espëcies da América tropical, a maioria do Brasil. Luehea divaricata, muito semelhante ao fössil descrito, é una ärvore comum de Minas Gerais e Rio de Janejxo atē o Rio Grande do Sul, na Mata Atlântica, po dendo penetrar no cerrado (RIZZINI, 1971).

\section{Piptadenia Bentham}

o gênero Piptadenia inclui 15 espécies com dis tribuição restrita à América tropical (MABBERLEY, 1987). De hābito arbōreo, é comum na Mata Atlântica, desde o nordeste até o sul do Brasil, mostrando preferência por solos úmidos (RIZZINI,1971).

\section{Cassia Linnaeus}

O gênero Cassia engloba aproximadamente 535 espẹ cies (MABBERLEY, 1987), que representam una ampla variedade de er vas, arbustos e ārvores amplamente distribuidos em todas as regiões tropicajs e temperadas quentes de todos os continentes, sendo especialmente abundante na América tropical (BERRY, 1916,1935). 
Schizolobium Vogel

o gênero Schizolobium inclui apenas duas espécies distribuídas pela América tropical (MABBERLEY, 1987), sendo considerado monotipico por alguns autores. Schizolobium parahyba, simi lar ao fóssil descrito, ē uma árvore comum na Mata Atlântica desde - sul da Bahia até o Rio Grande do Sul (RIZZINI, 1971).

\section{Machaerium Persoon}

O gênero Machaerium apresenta cerca de 120 espëcies distribuidas principalmente pela Amërica tropical (MABBERLEY, 1987). Compreende plantas de häbito arbóreo ou arbustivo, incluindo mui tas lianas (MABBERLEY, op.cit.).

\section{Sophora Linnaeus}

Sophora è uma leguminosa de häbito arbustivo ou ar bóreo, incluindo cerca de 52 espëcies, distribuídas nas regiões tro picais e temperadas (MABBERLEY, 1987).

Myreia De Candolle ex Guillarmod

o gênero Myrcia apresenta na atualidade mais de 400 espēcies distribuidas nas Américas tropical e sub-tropical, con centradas especialmente nas regióes centro-oeste e sudeste do Brasil (MC VAUGH, 1968, 1969, segundo KAWASAKI, 1984). De acordo com LEGRAND (1968, segundo KAWASAKI, 1984), a maioria das espécies 을 corre em Minas Gerais. Myrciarostrata, em especial, è uma espé cie muito comum, encontrada em todo o Brasil extra-amazônico, de- 
monstrando preferência por solos úmidos de capoeiras, orlas e cla reiras de matas (LEGRAND \& KLEIN, 1969).

\author{
Psidium Linnaeus \\ o gênero Psidium engloba aproximadamente 100
}

es pécies, de häbito arbustivo ou arböreo, distribuídas pela América tropical e sub-tropical, com major concentração da região amazôni ca até o sul do México (KAWASAKI, 1984). No Brasil, suas espécies são encontradas desde o Amazonas até o Rio Grande do Sul (KAWASAKI, op.cit.).

\title{
Bertolonia Raddi
}

O gênero Bextozonia, com 14 espécies, apresenta distribuição restrita ao Brasil (MABBERLEY, 1987). Bertolonia mosenii ē uma planta herbācea de baixa altitude, muito frequlente na Mata Atlāntica, nas proximidades de riachos (S.A.C. Chiea, infor mação verbal).

$$
\begin{aligned}
& \text { Byrsonima Richard ex Jussieu } \\
& \text { O gênero Byrsonima apresenta cerca de } 150 \text { espé }
\end{aligned}
$$
cies, de hābito arbustivo, distribuídas pela América tropical (MABBERLEY, 1987$)$.

\section{Sexjania Miller}

Constituido principalmente por trepadeiras de ma tas, o gênero Sexjania inclui cerca de 215 espécies tropicais e 
sub-tropicais (MABBERLEY, 1987), sendo que a maioria delas ocorre no Brasil (DUARTE, 1972).

\section{Zanthoxy Zum Linnaeus}

Zanthoxylum è uma planta de häbito arbóreo ou arbustivo, portadora de espinhos. Abrange cerca de 200 espécies, com ampla distribuição nas regiões tropicais e temperadas quentes, especialmente na América, Africa, Asia e Austrália (MABBERLEY,1987).

Tocoyena Aublet

O gênero Tocoyena inclui 20 espécies, distribuidas pela América tropical (MABBERLey, 1987). Pode apresentar hábi to sub-arbustivo, arbustivo ou arbóreo, chegando a alcançar até $25 \mathrm{~m}$ de altura (PRADO, 1987).

\section{Echinodorus Richard ex Engelmann}

Echinodorus è uma planta de hábito aquático, com folhas submersas, flutuantes ou emergentes, mas que tambëm pode ocorrer no sub-bosque (RATAJ, 1978). Apresenta cerca de 47 espé cies đistribuías pela América e Africa (MABBERLEY, 1987).

\section{Monstera Adans}

o gênero Monstera é constituído por 22 espécies de hābito herbāceo (liana) distribuảdas pela América tropical (MABBERLEY, 1987). Apresenta muitos representantes no Brasil. 
IFABEA 1 - Feições foliares de importancia paleoclimätica observadas nos gêneros presentes na tafoflora da Formação Itaquaquecetuba

ESPECTE

Ocotea pulchelliformis
Luehea divaricatiformis
Casearia serrata
Piptadenia tertiaria
Cassia rosleri
Schizolobium inaequilaterum
Machaerium piranii
Myrcia cf. rostrataformis
Psidium paulense

Bertolonia coimbrai

Aquifoliphyzlum izicioides * denteada

Rhamiphyllum caseariformis* inteira

Byrsonima bulzata

Serjania itaquaquecetubensis serrada

Serjania Zancifolia

Zanthoxyzum glanduziferum

Tocoyena riccominii

Echinodorus rossiae

Monstera marginata * inteira

serrada agudo

\section{MARGEM THPO DE \\ EPICE}

inteira

serrada

serrada

inteira

inteira

inteira

inteira

inteira

inteira

inteira

obtuso

emarginado

atenuado

inteira

inteira

inteira

inteira

(?)

(?)

agudo (?)

atenuado
TEXTURA

(?)

cartácea

(?)

cartácea (?)

cartäcea (?)

cartācea (?)

cartácea (?)

cartācea (?)

cartācea (?)

sub-coriäcea

(?)

cartácea

(?)

cartácea

cartācea

cartácea

arredondado

coriācea (?)

cartäcea

(?)

cartācea (?)

cartācea (?)

(?)

cartácea (?)

sub-cartäcea (?)

cartācea (?)
AREA

FOLIAR

$\left(\mathrm{cm}^{2}\right)$

3,6

7,2

2,8

0,7

2,0

5,1

2,3

4,0

3,4

2,9

2,2

22,3 
FABEha 2 - Häbito climático dos gêneros identificados na Formação Itaquaquecetuba, sugerindo fortemente um clima tropi cal umido, de acordo com suas ocorrências em matas atuais.

GENERO

$\begin{array}{llllll}\text { H } & \mathbf{A} & \mathbf{B} & \mathbf{I} & \mathbf{T} & \mathrm{O}\end{array}$

C I. I M A T I C O

TROPTCAI

OMIDO

SUB-TROPICAL

UMIDO

TEMPERADO QUENTE

OMIDO

Isotachis

$x$

Lindsaea

$\mathrm{x}$

ocotea

$\mathrm{x}$

$\mathrm{x}$

Luehea

$\mathrm{x}$

Casearia

$\mathrm{x}$

Piptadenia

X

Cassia

$\mathrm{x}$

$\mathrm{x}$

Schizolobium $x$

Machaerium $\mathrm{x}$

Sophora

$\mathrm{x}$

Myreia

$\mathrm{x}$

$\mathrm{x}$

Psidium

$\mathrm{x}$

$\mathrm{x}$

Bertolonia

$x$

Byrsonima

$x$

Serjania

$x$

$\mathrm{x}$

zanthoxyzum

x

$x$

Tocoyena

X

Echinodorus

x

Monstexa

X 


\subsection{RRESULTADOS}

Com base nos indicadores paleoclimáticos e na dis tribuição geográfica atual dos gêneros assinalados (tabela 2), é lícito admitir que a tafoflora estudada é sugestiva de uma mata tropical ümida, ou seja, de uma mata pluvial, visto que as formas identificadas apresentam equivalentes atuais que ocupam este tipo de ambiente.

\subsection{COMUENWRIOS}

A mata pluvial é típica das porções mais ümidas e chuvosas dos tröpicos, sendo geralmente densa e exuberante. Caracteriza-se pela parte aérea, constituída por numerosas e variadas formas de vida, que se ordenam em grupos estruturais denominados sinúsias e se dispõem em estratos (RIZZINI, 1979). Apresenta mar cante heterogeneidade, abrigando representantes de muitas familias, principalmente leguminosas, bignoniáceas, lauráceas e mirtáceas (TROPPMAIR, 1989), alēm de arbustos, palmeiras, fetos arborescen - : tes, ervas macrófilas e numerosas epifitas e lianas (RIZZINI, op. cit.). As árvores não apresentam portes muito elevados, e poucas perdem totalmente a folhagem de maneira periódica, predominando as perenifólias.

\subsection{DHSCUSSÃO}

Conforme visto anteriormente, a tafoflora aqui es- 
tudada é sugestiva de uma mata pluvial. Até certo ponto é cabivel supor, com base nas formas identificadas, que essa mata apresenta alguma similaridade com a atual Mata Atlântica. Esta formação vegetal, de acordo com a topografia e condições edáficas, pode ser subdivididas em vārias associações florísticas (KLEIN, 1975). RIZ ZINI (1979), por exemplo, distingue 4 formações na Mata Atlântica: floresta pluvial montana, floresta pluvial baixo-montana, flores ta de Araucaria e floresta pluvial ripäria e em manchas. E temerária, entretanto, qualquer tentativa no sentido de situar a tafo flora dentro de formações equivalentes, visto que a distinção é baseada em diversos aspectos, inclusive alguns dificilmente pre servados no documentärio paleontolögico. Desta forma, de momento, sem o risco de incorrer em erros de interpretação, pode-se afir mar apenas que a tafoflora está relacionada a uma mata sugestiva de condições climäticas úmidas.

A presença, associada à tafoflora, de pólens, de coniferas, os quais, segundo LIMA \& MELO (1989), seriam indicativos de clima não tropical, possivelmente seco, poderia ser explicada pelo fato destes pölens serem anemófilos e, portanto, transportäveis a enormes distâncias. Desta forma, os pólens esta riam relacionados à vegetação das porções mais altas do paleorele vo, onde o clima seria mais frio e seco. As folhas aqui estudadas, por sua vez, representariam uma amostragem mais local, onde os vegetais ocupariam as porções mais baixas do paleorelevo, em condições de clima mais quente e úmido (FITTIPALDI \& SIMÕES,1989). A ocorrência desses elementos evidenciaria, assim, a existência de uma zonação altitudinal ao longo das paleovertentes, de forma se melhante, grosso modo, ao que ocorre atualmente no Maciço de Ita- 
tiaia, no planalto de Campos de Jordão e nos Andes Colombianos.

Com base na presença de um sistema fluvial entrela çado ("braided"), e em datações por C-14, que sugeriram uma corre lação com glaciais e interglaciais do hemisfério norte, diversos autores admitiram a hipōtese de um clima semi-ärido para a época de deposição dos sedimentos da Formação Itaquaquecetuba. o ambiente semi-ärido, segundo PENTEADO (1978), é caracterizado por possuir médias anuais de temperatura muito elevadas, escassez e ixregularidade de precipitação, vegetação empobrecida e falta de rios perenes.

A presença de uma floresta pluvial pode ser considerada incompatível com um ambiente semi-ärido, desde que este tipo de formação vegetal estä associado a solos saturados de umi dade, em função de uma elevadarprecipitação anual. Alëm disto, em um clima semi-árido, a vegetação apresenta características xero mörficas, ao conträrio da tafoflora estudada, onde as folhas não mostram qualquer evidência de adaptação à semi-aridez climātica.

Alguns autores (AB'SABBER, 1978; 1980; SUGUIO,1980) admitiram que os troncos presentes na Formação Itaquaquecetuba po deriam estar relacionados à existência de matas galerias, mesmo sob condições regionais de aridez. Vale lembrar que tais troncos, que certamente não estão incluídos nos mesmos níveis orgânicos das folhas aqui estudadas, pertencem, segundo suguIo (1971) e suguIo \& MUSSA(1978), a gêneros atualmente viventes nas florestas ümi das da América tropical. De acordo com AB'SÄBER (op.cit.,), "as āguas, ora altas, ora baixas, transitando, cada vez mais, por sob 
areais, transportando novas areias de rio acima, faziam um efeito continuado de cortes e recheios ("cult and fill"), em canais anas tomosados de leito de rio largo e variável. No seu trânsito irregular e às vezes violento, levavam de roldão troncos de iārvores de uma paleo-mata galeria regional, anterior à generalização das florestas pluviais, atualmente predominantes no planalto Atlântico". Segundo suguro (1980), "embora os estudos paleo-anatômicos das madeiras fósseis tenham indicado condições climäticas do tipo tropical úmido para os ambientes em que viveram estas plantas, ainda existe a possibilidade de que os sedimentos associados tenham sido depositados em clima semi-ärido. Neste ültimo caso, as madeiras poderiam estar ligadas a matas galerias que se desenvol veram ao longo de cursos de água, mesmo em regiões semi-āridas". Entretanto, partindo da suposição de que o clima regional sesse semi-árido, fica difícil imaginar a ocorrência de uma mata típica de clima tropical úmido, mesmo que ciliar, dentro de um contexto regional caracterizado pela semi-aridez, pois, conforme salientado anteriormente, a irregularidade e a escassez de chuva neste ambiente não favorecem, com raras excessões, a existência de rios perenes. Somente rios muito volumosos como, por exemplo, o Rio São Francisco e o Rio Nilo, são perenes em regiões semi-äxidas, propiciando a presença permanente de uma mata ciliar.

As matas galerias, de outro lado, são caracterizadas por menor variedade de espécies e ausência quase completa de vegetação inferior (GONZAGA DE CAMPOS, 1912). Na associação estudada, porém, a diversidade de espécies, inclusive com a presença de briófitas e ptexidófitas, bem como a abundância de certas formas, são sugestivas de uma mata mais extensa. 
Da mesma forma, a presença de uma floresta mais extensa parece dificilmente compativel com um sistema fluvial entrelaçado onde, eventualmente, poderiam ocorrer apenas "ithas" de vegetação.

De acordo com RICCOMINI (1989), os niveis que contëm as folhas aqui estudadas correspondem a megaclastos. Se intraclāsticos, sexiam contempoxâneos à unidade e representariam cor pos aquosos efêmeros instáveis, isto é, sujeitos à erosão e retrabalhamento no sistema "braided" instalado com rāpida construção e destruição das barras transversais em resposta a distintos niveis das āguas em regimes torrenciais (Armando Marcio Coimbra, informa ção verbal). Se extraclásticos, poderiam pertencer ao mesmo con texto geolögico ou se constituirem em produtos de canibalismo de uma unidade sedimentar mais antiga.

Conforme sugerido por FITTIPALDI et al. (1989), com base nas conclusões de RICCOMINI (1989), os megaclastos seriam ex traclästicos. Desta forma, estes blocos, contendo os sedimentos já consolidados, seriam originados por retrabalhamento tectônico de sedimentos mais antigos, ricos em restos vegetais, referentes à facies de meandros abandonados da Formação são Paulo (sensu RICCO MINI, 1989), depositados sob condições ümidas.

Tais condições tambëm poderiam estar presentes época de deposição do sistema fluvial entrelaçado da Formação Itaquaquecetuba, conforme agora admitido por RICCOMINI (1989). Segun do RICCOMINI (op.cit.), a abundância de minerais instáveis naque Ia unidade, que tem sido interpretada como uma evidência de clima 
semi-áxido, poderia tex ocorrido sob condições ümidas, desde que - tectonismo fosse acentuado. Da mesma forma, em regime de alta pluviosidade, pode ocorrer a lavagem de lama, com perfeita segregação dos minerais. Alēm disto, a microflora da Cidade universitá ria, em sedimentos não retrabalhados, tambēm referĩveis à Forma ção Itaquaquecetuba, apresenta predominância de esporos de pteridöfitas, o que poderia sugerir um clima úmido. Evidências adicionais a favor de um clima umido poderiam ser dadas ainda: pelos troncos que, embora possam tex sofxido algum transporte, são de carātex local. Considerando o conteüdo fossilifero mais jmportan te na definição paleoclimätica do que o tipo de drenagem estabelecida, que estā ligada mais diretamente ao regime tectônico então vigente, RICCOMINI (op.cit.) defende, portanto, a hipótese de um clima úmido para o sistema fluvial entrelaçado da Formação I taquaquecetuba.

Admitindo-se como mais provävel a hipōtese dos megaclastros serem extraclāsticos, ainda restariam dūvidas com rela ção ao tempo transcorrido entre a deposição dos sedimentos fossiIiferos e o retrabalhamento tectônico, bem como com relação à dis tância entre a ārea fonte e o sitio deposicional.

No que se refere à distância percorrida pelos blocos, seria lícito supor que não tenha sido muito grande, desde que os mesmos, ainda que consolidados, não resistiriam a um transporte muito prolongado. Tais blocos podexiam ser considerados, por tanto, para-autóctones.

o tempo transcorrido entre a deposição dos sedimen 
tos fossiliferos e seu retrabalhamento, contudo, ainda é passivel de muita discussão. Enquanto que, com base palinológica, os megaclastos podem ser atribuidos ao Oligoceno (LIMA \& MELO, 1989), os depósitos da Formação Itaquaquecetuba carecem de datação mais precisa. Embora FITTIPALDI et al. (1989) tenham admitido que os megaclastos seriam provenientes de uma unidade sedimentar mais antiga, não deve ser descartada a possibilidade deles pertencerem ao mesmo contexto geológico. Aparentemente, porēm, não seriam penecontemporâneos, considerando que uma análise palinológica preli minar descarta uma idade oligocênica para os depósitos da Forma ção Itaquaquecetuba anteriormente expostos na atual raia olimpica da Cidade Universitāria, em função da quase que completa ausência de polens dissacados (RICCOMINI, 1989). No entender deste autor,o sistema fluvial entrelaçado de Itaquaquecetuba, com base em argumentos de ordem tectônica, sedimentar e paleontológica, poderia certamente ser referido ao intervalo de tempo pös-oligoceno: a pré-pleistoceno superior. Desta forma, embora faltem evidências, deve ser considerada a possibilidade dos blocos terem sido retrabalhados apōs um tempo geologicamente curto, compatível com a per sistência das condições climäticas. Neste caso, as informações paleoambientais fornecidas pelos vegetais apenas seriam válidas para a região onde os blocos se depositaram se, na área tipo, eles fossem penecontemporâneos à sedimentação, ao contrārio do admitido para a raía olímpica. De outro lado, considerando a possibili dade de um intervalo de tempo geológicamente maior, as condições dificilmente teriam persistido inalteradas, embora, a julgar pe las evidências paleoclimáticas fornecidas pelos trancos, bem como pelas ponderações de RICCOMINI (op.cit.) anteriormente citadas, seja perfeitamente admissível um clima também úmido para a época de deposição dos sedimentos da Formação Itaquaquecetuba. 


\section{CAPITULO 6}

\section{CONSTUERAÇÕES FINATS}

- A tafoflora estudada é constituída por restos de angiospermas (dicotiledôneas e monocotiledôneas), pteridófitas e briófitas.

- Com base na grande similaridade entre as folhas fösseis seus correspondentes modernos, todas as formas estudadas podem ser atribuídas a gêneros atuais, alguns dos quais ainaa não registrados em outros depósitos cenozöicos brasileiros.

Dentre os restos, há um aparente predominio de leguminosas e mirtáceas, que constituem mais de 50\% dos espécimes identifi cados. A forma mais abundante è Myrcia cf. rostrataformis.

- Com exceção de Myrcia cf. rostrataformis,todas as $:$ formas são distintas, a nivel específico, de fósseis assinalađos em outros depósitos cenozóicos brasileiros.

- Os restos incluem os primeiros fósseis de briófitas assinalados no Cenozóico brasileiro.

A tafoflora estudada é sugestiva de uma mata tropical úmidalma ta pluvial), visto que as formas identificadas apresentam e quivalentes atuais que ocupam este tipo de ambiente. 
- A presença de pólens de coníferas nos mesmos níveis das Ihas poderia ser explicada por uma zonação altitudinal, na qual estas confferas estariam relacionadas à vegetação das porções mais elevadas do terreno, onde o clima seria mais frio e seco.

Os vegetais identificados apresentam, a nỉvel genérico, peque na utilidade em correlações temporais, já que, devido à sua grande distribuição ao Iongo do Cenozóico, não são diagnósti cos do ponto de vista cronológico. E possivel, porëm, que o estudo pormenorizado de um grande nümero de ocorrências, venha a destacar elementos üteis para correlações.

- As informações paleoambientais fornecidas pelos vegetais estudados sexiam tambëm välidas para a região onde os megaclas tos se depositaram, apenas no caso destes serem penecontempo râneos à sedimentação, o que implicaria em um espaço de tem po compativel com a persistência das condições climáticas. 


\section{REFERENCIAS BTBLIOGRAFICAS}

AB'SÁBER, A.N. (1978) A planície do Tietê no planalto paulistano. Geomorfologia, $57,24 \mathrm{p}$.

AB'SĀBER, A.N. (1980) súmula geomorfológica da região de são Pau1. In: MESA REDONDA SOBRE ASPECTOS GEOLOGICOS E GEOTECNICOS DA BACIA SEDIMENTAR DE SÃo PAULO. São Paulo, 1980. Anais. São Pau Io, $\mathrm{ABGE}-\mathrm{SBG}, \mathrm{p} .33-36$.

ALMEIDA, F.F.M. (1952) Novas ocorrências de camadas supostas plio cênicas nos estados de são Paulo e Paraná. Boletim da Sociedade Brasileira de Geologia, 1(1): 53-58.

ALMEIDA, F.F.M. (1955) As camadas de são Paulo e a tectônica da Serra da Cantareira. Boletim da Sociedade Brasileira de Geologia, $\underline{4}(2): 23-40$.

ALMEIDA, F.F.M. (1957) Vale do Paraíba. In: Departamento Nacio nal da Produção Mineral. Divisão de Geologia e Mineralogia. Relatório Anual do Diretor, p. 90-91.

ALMEIDA, F.F.M. (1976) The system of continental rifts bordering the Santos Basin, Brasil. Anais da Academia Brasileira de Ciências, 48 (supl.): 15-26.

ALMEIDA, F.F.M. \& BARBOSA, O. (1953) Geologia das quadriculas de Piracicaba e Rio Claro, Estado de são Paulo. Boletim Divisão de Geologia e Mineralogia, 143: 1-96. 
ALMEIDA, F.F.M.; RICCOMINI, C.; DEHIRA, L.K.; CAMPANHA, G.A.C. (1984) Tectônica da Formação Itaquaquecetuba na grande são Pau 10. In: CONGRESSO BRASILEIRO DE GEOLOGIA, 33., Rio de Janeiro, 1984. Anais. Rio de Janeiro, SBG, v.4, p. 1794-1808.

ANDREWS JR, H.N. (1970) Index of generic names of fossil plants, 1820-1965. Geological Survey Bulletin, 1300: 1-354.

ARAI, M. (1987) Estudo petrográfico preliminar dos troncos carbonificados da Formação Itaquaquecetuba. Boletim IG, 17: 99-107.

ATENCIO, D. (1986) Sulfatos secundärios: relação com rochas pré existentes e sintese. São Paulo, Universidade de são Paulo, 210p. (Tese de Mestrado - Instituto de Geociências).

BAILEY, I.W. \& SINNOTT, E.W. (1915) A botanical index of Cretaceous and Tertiary climates. Science, 41: 831-834.

BARROSO, G.M. (1978) Sistemätica de Angiospermas do Brasil. v. 1. LTC/EDUSP, $255 \mathrm{p}$.

BECKER, H.F. (1969) Fossil plants of the Tertiary Beaverhead Ba sins in Southwestern Montana.Palaeontographica B. , 127(1-6) : $1-142$.

BERRY, E.W. (1916) The Lower Eocene floras of southeastern North America. U.S. Geol. Surv. Prof. Paper, 91, 481p. 
BERRY, E.W. (1925) Tertiary plants from eastern peru. Studies in Geology. Johns Hopkins University, 6: 163-1.81.

BERRY, E.W. (1929) The fossil flora of the Loja Basin in Southern Ecuador. Studies in Geology. Johns Hopkins University, 10: $79-135$.

BERRY, E.W. (1935) Tertiary plants from Brazil. Proc. Am. Phil. Soc., $75(7): 565-590$.

BERRY, E.W. (1937) Late tertiary plants from the territory of Acre, Brazil. Studies in Geology. Johns Hopkins University, 12: $81-90$

BIGARELLA, J.J. (1971) Variações climāticas no Quaternārio supe rior do Brasil e sua datação radiomētrica pelo método do carbono 14. Paleoclimas, 1:1-22.

BIGARELLA, J.J. (1975) Topics for discussion. Boletim Paranaense de Geociências, 33: 171-276.

BIGARELIA, J.J.; ANDRADE-LIMA, D. \& RIEHS, P.J. (1975) Considerações a respeito das mudanças paleoambientais na distribuição de algumas espēcies vegetais e animais no Brasil. Anais da Aca demia Brasilejra de Ciências, 47 (supl.) : 411-464.

BIGARELLA, J.J. \& MOUSINHO, M.R. (1965) Contribuição ao estudo da Formação Pariquera-Açu, Estado de são Paulo. Boletim Paranaense de Geografia, 16/17: 17-41. 
BIRKS, H.J.B. \& BIRKS, H.H. (1980) Quaternary Palaeoecology. London, Edward Arnold, 289p.

BJORNBERG, A.J.S.; LANDIM, P.M.B. \& MEIRELES FILHO, G.M. (1964) Restos de plantas modernas em níveis elevados na região de Rio Claro - São Paulo. Publ. Esc. Eng. S.Carlos, USP, 106: 35-57.

BJORNBERG, A.J.S. \& LANDIM, P.M.B. (1966) Contribuição ao estudo da Formação Rio Claro (Neocenozóico). Boletim da Sociedade Bra sileira de Geologia, 15(4): 43-67.

BURNHAM, R.J. (1986) Foliar morphological analysis of the Ulmoi deae (Ulmaceae) Exom the Early Tertiary of Western North Ameri ca. Palaeontographica B., 201 $(5-6): 135-167$.

CAIN, S.A.; CASTRO,G.M.O.; PIRES, J.M. \& SILVA, N.T. (1956) Appli cation of some phytosociological techniques to Brazilian rain forest. Part. I. Forest Composition of Arapari Island, Pará. Américan Journal of Botany, 43: $911-941$.

CHING, R. (1978) The chinese fern families and genera: systematic arrangement and historical origin (cont.). Acta Phytotax. Sinica, I6 (4): $16-37$.

COIMBRA, A.M.;'RICCOMINI, C. \& MELO, M.S. (1983) A Formação Ita quaquecetuba: evidências de tectonismo no Quaternário paulis ta. In: SIMPOSIO REGIONAL DE GEOLOGIA, 4., São Paulo, 1983. Atas. São paulo, p. 253-266. 
COLTRINARI, L.; NAKASHIMA, P. \& QUEIROZ NETO, J.P. (1984) Evolução quaternária do vale médio do Rio Parateí, Estado de são Paulo Brasil. Revista do Departamento de Geografia, 3:7-19.

CREPET, W.L. \& TAYLOR, D.W. (1985) The diversification of the Legu minosae: first fossil evidence of the Mimosoideae and papilio noideae. Science, 228: 1087-1089.

CRONQUIST, A. (1981) An integrated system of classification of flowering plants. New York, Columbia University Press, 1262 p.

DILCHER, D.L. (1963) Cuticular analysis of Eocene leaves of Ocotea. obtusifolia. American Journal of Botany, 50: 1-8.

DILCHER, D.L. (1969) Podocarpus from Eocene of North America. Scien ce. 164: 299-301.

DILCHER, D.L. (1974) Approaches to the identification of angiosperm leaf remains. The Botanical Review, 40(1): 1-157.

DILCHER, D.L. \& DOLPH, G.E. (1970) Fossil leaves of Dendropanax from Eocene sediments of southeastern North America. American Journal of Botany, 57: 153-162.

DOLPH. G.E. \& DILCHER, D.L. (1979) Foliar physiognomy as an aid in determining paleoclimate. Palaeontographica B., 170(4-6): 151 172 . 
DOLPH. G.E. \& DILCHER, D.L. (1980a) Variation in leaf size with respect to climate in Costa Rica. Biotropica, 12(2): 91-99.

DOLPH, G.E. \& DILCHER, D.L. (1980b) Variation in leaf size with respect to climate in the Western Hemisphere. Bull. Torrey Bot. Club, $107(2): 154-162$.

DOLIANITI, E. (1949) Contribuição à flora pliocênica de Fonseca, Minas Gerais. Anais da Academia Brasileira de Ciências, 21 (3): 239-244.

DOLIANITI, E. (1950) Contribuição à flora pliocênica de Fonseca, Minas Gerais, II - Luhec roxoi n.sp. Anais da Academia Brasi leira de Ciências, $22(3): 303-306$.

DOLIANITI, E. (1955) Frutos de Nipa no Paleoceno de Pernambuco, Brasil. Boletim Divisão de Geologia de Mineralogia, 158: 7-36.

DUARTE, L. (1956) Melastomataceae fósseis da Bacia Terciāria de Fonseca, Minas Gerais. Boletim Divisão de Geologia e Mineralo gia, 161: 7-28.

DUARTE, L. (1972). Flórula da Formação Pirabas, Estado do Parā , Brasil. São Paulo, Universidade de são Paulo, 156p. (Tese de Doutorado - Instituto de Geociências.

DUARTE, L. (1979) Sobre uma Filicínea (Lastrea dardanoi n. sp.) do Quaternáxio do Estado da Paraüba. Anais da Academia Brasileira de Ciências, 51(4): 741-746. 
DUARTE, L. (1985) Pteridophyta da Bacia de Fonseca, Minas Gerais. In: Coletânea de trabalhos paleontológicos, MME, DNPM, p. 553555 (Geol., 27).

DUARTE, L. \& MANDARTM-DE-LACERDA, A.F. (1987) Flora Cenozóica do Brasil: Formação Txemembé, Bacia de Taubaté, sp. (Nota prelimi nar). In: CONGRESSO BRASTLEIRO DE PAIEONTOLOGIA, 10., Rio de Janeiro, 1987. Anais. v.2, p. 879-884.

DUARTE, L. \& MELI.JO FILHA, M.C. (1980) Flórula cenozóica de Gandâ rela, MG, I. Anais da Academia Brasileira de Ciências, 52 (1): 77-91.

DUARTE, L. \& NOGUEIRA, M.I.M. (1980) Vegetais do Quaternärio do Brasil, I flórula de Russas, CE. Anais da Academia Brasilejra de ciências, $52(I): 37-48$.

DUARTE, L. \& REZENDE-MARTINS, A.F.P. (1983) Contribuição ao :Conhecimento da Flora Cenozóica do Brasil: Jazigo Vargem Grande do Sul, SP. Série Taubaté, I. Anais da Academia Brasileira de Ciências, $55(1): 109-121$.

DUARTE, L. \& REZENDE-MARTINS, A.F.P. (1985) Contribujção ao co nhecimento da Flora Cenozóica do Brasil: Jazigo Vargem Grande do Sul, SP. Série Taubaté, II: In: Coletânea de trabalhos pa leontológicos. MME, DNPM, p. 565-571 (Geol., 27).

DUARTE, L. \& VASCONCELOS, M.E.C. (1980) Vegetais do Quaternārio do Brasil, II Flórula de Umbuzeiro, PB. Anais da Academia Brasileira de ciências, 52(I): 93-108. 
ETITNGSHAUSEN, C. VON (1861) Die Blattskelete der Dikotyledonen mit besondere Riicksicht auf die Untersuchung und Bestimmung der fossilen Pflanzenrest. KBn. Hof. und Staatsdruckerei, Wein, $308 \mathrm{p}$.

FERNANDES, G.W. (1987) Gall forming insects: their economic importance and control. Revista Brasileira de Entomologia, 31 (3) : $379-398$

FERNANDES, G.W.A. \& MARTINS, R.P. (1985) As galhas. Ciência Hoje, $4(19): 58-64$.

FIPTIPALDI, F.C. \& ROSLER, O. (1987) As plantas fósseis como in dicadores paleoclimāticos. In: CONGRESSO BRASILEIRO DE PALEONTOLOGIA, 10., Rio de Janeiro, 1987. Anais. Rio de Janeiro, SBP, v. 2, p. $925-936$.

FITTIPALDI, F.C. \& SIMÕES,M.G. (1989) Estado Atual do conhecimen to sobre a Paleontologia da Bacia de São paulo. In: WORKSHOP "GEOLOGIA DA BACIA DE SÃo PAULO" , São Paulo, 1989. Coletânea das Comunicações. São Paulo, Instituto de Geociências, Sociedade Brasileira de Geologia, 1989. p. 27-34.

FITTIPALDI, F.C.; SIMÕES, M.G.; GIULIETTI, A.M. \& PIRANI, J. R. (1989) Fossil plants from the Itaquaquecetuba Formation (Ceno zoic of the São paulo Basin) and their possible paleoclimatic significance. Boletim IG, Publicação Especial, 7, p. 183-203. 
FITIIPALDI, F.C. \& SIMÕES, M.G. (1990) Maxcas de possiveis galhas provocadas por insetos em folhas de angiospermas fósseis da Formação Itaquaquecetuba (Cenozóico, Bacia de são paulo). In: CONGRESSO BRASILETRO DE ZOOLOGIA, 17., LONdrina, 1990. Resumos. p. 54 .

FLENLEY, J. (1979) The Equatorial Rain Forest: a geological history. London, Butterworths, $162 \mathrm{p}$.

FULFARO, V.J.; OLIVEIRA, M.A.F.; MORALES, N. \& SOUZA FILHO, E.E. (1985) Evolução cenozóica da região de Atibaia, SP. In: SIMPOSIO REGIONAL DE GEOLOGIA, 5., São Paulo, 1985. Atas. São Paulo, p. 315-321.

FULFARO, V.J. \& SUGUIO, K. (1968) A Formação Rio Claro (Neocenozóico) e seu ambiente de deposição. o I.G.G., 20: 45-60.

FOLFARO, V.J. \& SUGUIO, K. (1974) o cenozóico paulista: gênese e idade. In: CONGRESSO BRASILEIRO DE GEOLOGIA, 28. , Porto Alegre, 1974. Anais, Porto Alegre, SBG, v.3, p.91-101.

GIULIETTI, A.M.; PIRANT, J.R.; FITTIPALDI, F.C. \& SIMÕES, M. G. (1988) Restos de vegetais da Formação Itaquaquecetuba (Cenozöi co da Bacia de são Paulo). In: CONGRESSO NACIONAL DE BOTÂNICA, 39. Belëm, 1988. Resumos. p.251.

GOEBEL, K. (1905) organography of plants. Oxford. 
GONZAGA DE CAMPOS, I.F. (1912) Mappa Florestal. Serviço Geológico e Mineralógico do Brasil, $102 \mathrm{p}$.

GOOD, R. (1964) The geography of the flowering plants. New York, John Wiley \& Sons Inc., 518p.

GORCEIX, M.H. (1876) Note sur la roche connue vulgairement au Brẹ sil sous le nom de Canga, et sur le bassin d'eau douce de Fonse ca (province de Minas Geraes). Bu11. Soc. Geol. France, 3ëme Ser, 4 : $321-323$.

GORCEIX, H. (1884) Bacia terciaria d'agua doce nos arredores de ou ro Preto (Gandarela e Fonseca) Minas Geraes - Brasil. Annaes da Escola de Minas de Ouro Preto, 3: 75-92.

HASUI, Y.; CARNEIRO, C.D.R. \& COTMBRA, A.M. (1975) The Ribeira Folded Belt. Revista Brasileira de Geociências, $5(4):$ 257-266.

HASUY, Y.; PONÇANO, W.I. ; BISTRICHI, C.A.; STEIN, D.P.; GALVÃO, C. A.C.F.; GIMENEZ, A.F.; ALMEIDA, M.A.; PIRES NETO, A.G.; MELO , M.S. \& SANTOS, M.C.S.R. (1978) Geologia da região administrativa 3 (Vale do Paraíba) e parte da região administrativa 2 (Tito ral) do Estado de São Paulo. Monografias IPT, $1,78 p$.

HEYWOOD, V.H. (ed.) (1979) Flowering plants of the world. Oxford, Oxford University Press, 335p. 
HICKEY, L.J. (1973) Classification of the architecture of dicotyle donous leaves. American Journal of Botany, 60: 17-33.

HICKEY, I.J. (1979) A revised classification of the architecture of dicotyledonous leaves. In: METCALFE, C.R. \& CHALK, L. (ed.).Ana tomy of the dicotyledons. v.1, ed.2, oxford, clarendon press, p. $25-39$.

HICKEY, L.J. \& WOLFE, J.A. (1975) The bases of angiosperm phylogeny: vegetative morphology. Ann. Mo. Bot. Gard., 62: 538-589.

HOLLICK, A. \& BERRY, E.W. (1924) A late tertiary flora from Bahia, Brazil. Studies in Geology. Johns Hopkins University, 5: 11-136.

Joly, A.B. (1983) Botânica. Introdução à taxonomia vegetal. 6.ed. Editora Nacional, $777 p$.

JOVET-AST, S. (1967) Briophyta. In: BOUREAU, E. (ed.). Traité de Paleobotanique. v.2. Paris, Masson et Cie.,p. 19-186.

JUNQUEIRA, C.B. (1969) Camadas cruzadas de areia, gravas e casca Thos fluviais do Vale do Pinheiros ("Campus" da Cidade Universi täria). Geomorfologia, 10: 7-9.

JUPJAssú, A.M.S. (1970) Madeira fóssil - Mumiriaceae de Ixituia, Estado do Pará. Boletim do Museu Paraense Emilio Goeldi, Geol. 14: $1-15$. 
KAWASAKI, M.L. (1984) A familia Myrtaceae na serra do Cipó. São Paulo, Universidade de São Paulo, 202p. (Tese de Mestrado Instituto de Biociências).

KERNER VON MARILAUN, A.J. (1895) The natural history of plants. v.1. New York, Holt.

KLEIN, R.M. (1975) Southern brazilian phytogeographic features and the probable influence of upper quaternary climatic changes in the floristic distribution. Boletim Paranaense de Geo ciências, $33: 67-88$.

KNOWLTON, F.H. (1917) Fossil Floras of the vermejo and Raton For mations of Colorado and New Mexico. U.S.Geol.Surv.prof.Paper, 101: $223-455$.

KNOWLTON, F.H. (1924) Flora of Animas Formation. U.S.Geol.Surv. Prof. Paper, 134: 71-117.

KRAMER, K.U. (1957) A revision of the genus Lindsaea in the new world. Acta Botanica Neerlandica, 6: 97-290.

LAM, H.J. (1925) The Sapotaceae, Sarcospermaceae, and Boerlagellaceae of the Dutch East Indies and surrounding countries. Bull. Jard. Bot. Buitenzorq III, 8: 1-289.

LAMOTTE, R.S. (1952) Catalogue of the Cenozoic Plants of North America through 1950. Memoir of the Geological Society of America, 51: 1-381. 
IJEE, A.T. (1948) The genus Swainsona. Contrib. New: South wales Herb., 1: 131-271.

LEGRAND, C.D. \& KLEIN, R.M. (1978) Mìrtáceas. In: REITZ, R. (ed.). Flora Ilustrada Catarinense, p. 731-876.

LIMA, M.R. ; SALARD-CHEBOLDAEFF, M. \& SUGUIO, K. (1985a) Etude pa lynologique de la Formation Tremenbé, Textiaire du Bassin de Taubatē, (Etat de são Paulo, Bresil), d'apres les echantillons du sondage no 42 du CNP. In: Coletânea de trabalhos paleontológicos, MME, DNPM, Geol. no 27: 379-393.

LIMA, M.R.; VESPUCCI, J.B.O. \& SUGUIO, K. (1985b) Estudo palinolögico de uma camada de Iinhito da Formação Caçapava, Bacia de Taubatē, Terciārio do Estado de São Paulo; Brasil. Anais da Aca demia Brasileira de Ciências, $57(2): 183-197$.

LIMA, M.R. \& MELO, M.S. (1989) Palinologia de sedimentos da Bacia de são paulo. In:WORKSHOP "GEOLOGIA DA BACIA DE SÃO PAULO"- São Paulo, 1989. Coletânea das Comunicações. São Paulo, instituto de Geociências, Sociedade Brasileira de Geologia, 1989. p. 35-37.

MARBERLEY, D.J. (1987) The plant-book. Cambridge, Cambridge Univer sity Press, 706p.

MAC GINITIE, H.D. (1969) The Eocene Green River flora of northwestern Colorado and northeastern Utah. Univ.Calif.Publ.Geol.Sci., 83, $203 p$. 
MAGALHÃES, J. (1948) Sôbre a ocorrência de vegetal fössil na Fazen da são José, Mun. de Guaxindiba, RJ. Mineração e Metalurgia, 13 (73): 36 .

MANDARIM-DE-IJACERDA, A.F.; PONS, D. \& DUARTE, L. (1986) Contribu tion à I'étude d'une taphoflore du Cenozoique du Bresil: gisement mine "Nossa Senhora da Guia", Bassin de Taubaté, Etat de São Paulo. Anais da Academia Brasileira de Ciências, 58 (4):606.

MARCELLO, E.P. (1981) Ocorrência de fósseis vegetais na Formação Pariqliera-Açu; na região de Iguape, SP. Revista do Instituto Gè Iógico, $2(2): 47$.

MARTIN, L.; SUGUIO, K. \& FLEXOR, J.M. (1979) Le quaternaire marin du littoral brësilien entre Cananéia (SP) e Guaratiba outlet (RJ). In INTERNATIONAL SYMPOSIUM ON COASTAL EVOLUTION QUATERNARY, São Paulo, 1978. Special Publication. São Paulo, IGCP/IGUSP/SBG,1979. p. $296-331$.

MAURY, C.J. (1937) Argilas fossilíferas do Pliocênio do territó rio do Acre. Boletim Serviço Geológico e Mineralógico do Brasil, 77: $1-29$.

MCCLURE, D.S. (1957) Seed characters of selected plant families. Iowa State College Journal of Science, $31(4): 649-682$.

MELO, M.S. (1984) Géologie du Bassin de Resende et contribution a I'évolution du systeme de rift du SE du Brésil. Rapport de D.E. A., Universite d'Aix - Marseille I et II, 62p. 
MELO, M.S.; CAETANO, S.I.V. \& COIMBRA, A.M. (1986) Tectênica e sedimentação na área das bacias de são paulo e Taubaté. In: CoN GRESSO BRASILEIRO DE GEOLOGTA, 34., Goiânia, 1986. Anais, Goiânia, $\mathrm{SBG}, \mathrm{v}, 1, \mathrm{p}, 32-336$.

MELO, M.S.; COIMBRA, A.M. \& RICCOMINI, C. (1989) Evolução dos co nhecimentos sobre a geologia da Bacia de são Paulo na década de oitenta. In: WORKhOSP "GEOLOGIA DA BACIA DE SÃO PAULO". , são Pau 1o, 1989. Coletânea das Comunicações. São Paulö, Instituto de Geociências, Sociedade Brasilejra de Geologia, 1989. p.1-1.1.

MELO, M.S.\& PONÇANO, W.L. (1983) Gênese, distribuição e estratigra fía dos depósitos cenozóicos no Estado de são paulo. Monogra fias IPT, 9,75p.

MELO, M.S.; RICCOMINI, C. ; HASUI, Y.; AIMEIDA, F.F.M. \& COIMBRA,A. M. (1985) Geologia e evolução do sistema de bacias tafrogênicas continentais do sudeste do Brasil. Revista Brasileira de Geociências, 15(3): 193-201.

MEZZALIRA, S. (1948) Nota preliminar sobre a ocorrência de vege tais fósseis no município de Piracaia, sp. Mineração e Metalur gia, $13(73): 36$.

MEZZALIRA, S. (1950) Ocorrência de vegetais fösseis no município de são paulo. Mineração e Metalurgia, 14 (84):162. 
MEZZALIRA, S. (1959) Nota preliminar sobre as recentes descobertas paleontológicas no Estado de São Paulo no período 1958-1959. No tas prëvias, IGG, 2 : $1-7$.

MEZZAJIRA, S. (1961-62) Novas ocorrências de vegetais fösseis ceno zóicos no Estado de São Paulo. Revista do Instituto Geogräfico e Geológico, 15 (ünico): 73-94.

MEZZALIRA, S. \& PAULA COUTO, C. (1971) Nova conceituação geogronológica de Tremembē, Estado de são paulo, Brasil. Anais da Aca demia Brasileira de Ciências, 43 (supl.): 473-488.

MORAES REGO, I.F. \& SOUZA SANTOS, T.D. (1938) Contribuição para o estudo dos granitos da Serra da Cantareira. Boletim do Instituto de Pesquisas Tecnolögicas de são paulo, 18.

$\because$

MOUTON, J.A. (1985) Morphologie foliaire: nouvelles perspectives. In: CONGRES NATIONAL DES SOCIETES SAVANTES, Montpel1ier, 1985. Fasc. t. 3, p. $267-276$.

MUSSA, D. (1958) Dicotiledôneo fössil da Formação Barreiras, Estạ do de Sergipe. Boletim Divisão de Geologia e Mineralogia, 181: $1-48$.

MUSSA, D. (1959) Contribuição à paleoanatomia vegetal. II - Madei ras fósseis do território do Acre (Alto Juruá), Brasil. Bole tim Divisão de Geologia e Mineralogia, 195: 1-41. 
NIKLAS, K.J. \& GIANNASI,D.E. (1978) Angiosperm paleobiochemistry of the Succor Creek Flora (Miocene) Oregon, USA. American Jour nal of Botany, 65: 943-952.

OKA-FIORI, C. (1987) Mapeamento das formações superficiais entre Piracicaba e são Carlos (SP). Boletim Paranaense de Geoci ências, 37: 53-64.

PENALVA, F. (1971) Sedimentos neo-cenózóicos nos vales dos rios Jundiaí, Atibaia e Jaguari (Estado de são Paúlo). Boletim pau Iista de Geografia, 46: 107-138.

PENTEADO, M.M. (1978) Fundamentos de Geomorfologia. Rio de Janei ro, IBGE, 180p. (Série $D, 3$ ).

PETRI, S. \& SUGUIO, K. (1973) Stratigraphy of the Iguape - Cana néia ragaonal region sedimentary deposits, são paulo, state, Brazil, part II; heavy mineral studies, microorganism invento ries and stratigraphical interpretations. Boletim IG, 4: 7185.

PISSIS, A. (1842) Mëmoire sur la position géologique des terrains de la partie australe au Brésil, et sur les soulevements qui, à diverses époques, on changé le relief de cette contrēe. Aca demie des Sciences, Paris, Comptes Rendus, XIV, p.1044-1.046.

PONÇANO, W.L. (1981) o cenozóico paulista. In: ALMEIDA,F.F.M. et al. Mapa geolögico do Estado de São paulo; escala 1:500.000. São paulo, IPT. p. 82-96. (IPT publicação 1184) (Série Monogra fias 6). 
PRADO, A.L. (1987) Revisão taxonômica do gênero Tocoyena Aubl. (Rubiaceae) no Brasil. Campinas, Universidade de Campinas, $193 p$. (Tese de Mestrado - Instituto de Biologia).

RAGONHA, E.W. (1982) Evolução tecto-sedimentar da Bacia de Taubaté com fundamento na sua ictiofauna. Anais da Academia Brasileira de ciências, 54(4): 679-689.

RATAJ, K. (1978) Alismataceae of Brazil. Acta Amazonica, 8(1): suplemento I.

RAUNKIAER, C. (1934) The life forms of plants and statistical plant geography. Oxford, Oxford University Press.

RICCOMINI,C. (1989) O rift continental do sudeste do Brasil. São Paulo, Universidade de São Paulo. (Tese de Doutorado - Institü to de Geociências).

RICCOMINI, C.; TESSLER,M.G. \& SUGUIO, K. (1987) Novas evidências de atividade tectônica moderna no sudeste brasileiro: os depósitos falhados da Formação Pariquera-Açu. Proceedings of the IGCP Project 201 Mérida(Venezuela) Meeting: 29-42.

RICHARDS, P.W. (1952) The Tropical Rain Forest. Cambridge, Cambridge university press, $450 \mathrm{p}$.

RIGBY, J.F. (1971) Some palaeobotanical observations concerning the Bowen Basin. Proc. Second Bowen Basin Symp., Geol. Surv. of Queensland Report, 62: 21-29. 
RIZZINI, C.T. (1971) Arvores e madejras üteis do Brasil. Manual de Dendrologia Brasileira. São Paulo, Edgar Blucher, $296 \mathrm{p}$.

RIZZINI, C.T. (1979) Tratado de Fitogeografia do Brasil. Aspectos sociológicos e floristicos. 28 volume. Editora HUCITEC, EDUSP, $374 \mathrm{p}$.

ROBERTS, N. (1989) The Holocene. An Environmental History. Oxford, Basil Blackwell Ltd., $227 \mathrm{p}$.

ROSSI, L. (1987) A flora arbóreo-arbustiva da mata da reserva da Cidade Universitária Armando de Salles oliveira. São Paulo, Uni versidade de São Paulo, 270p. (Tese de Mestrado - Instituto de Biociências).

SCHUSTER, R.M. (1984) Evolution, phylogeny and classification of the Hepaticae. In: SCHUSTER, R.M. (ed.). New Manual of Bryology. v.2. p. $893-1070$.

SEGADAS-VIANNA, F. (1965) ECology of the Itatiaia Range. Southeastern Brazil. Arquivos do Museu Nacional, 53: 7-53.

SHEFFY, M.V. (1972) A study of the Myriaceae fram Eocene sediments of southeastern North America. Indiana, Indiana University. 152 p. (Ph.D. dissertation - Department of Plant sciences).

STEBBINS JR, G.I. (1950) Variation and Evolution in Plants. New York, Columbia University Press, 643p. 
STEWART, W.N. (1985) paleobotany and the evolution of plants. Cam bridge, Cambridge University Press, $405 p$.

SUGUIO, K. (1971) Estudo dos troncos de ärvores "linhitificados" dos aluviões antigos do Rio Pinheiros (São Paulo): significa dos geocronológico e possivelmente paleoclimātico. In: CONGRES SO BRASILEIRO DE GEOLOGIA, 25. , São Paulo, 1971. Anais. São Paulo, SBG, v.1, p.63-65.

SUGUIO, K. (1980) Sintese dos conhecimentos sobre a sedimentação da Bacia de são paulo. In: MESA REDONDA SOBRE ASPECTOS GEOLOGI COS E GEOTECNICOS DA BACIA SEDIMENTAR DE SÃO PAULO. São Paulo, 1980. Publ.Esp. São Paulo, ABGE-SBG, p. 25-32.

SUGUIO, K.; COIMBRA, A.M.; MARTINS, C. ; BARCELOS, J.H.; GUARDADO, L.R. \& RAMPAZZO, L. (1971) Novos dados sedimentológicos dos a luviões antigos do rio Pinheiros (são Paulo) e seus significados na interpretação do ambiente deposicional. In: CONGRESSO BRASILEIRO DE GEOLOGIA, 25., São Paulo, 1971. Anais. São PauIo, SBG, v.2., p.219-225.

SUGUIO.", K. \& MARTIN, L. (1976) Presença de tubos fósseis de "CaI lianassa" nas formações quaternārias do litoral paulista e sua utilização na reconstrução paleoambiental. Boletim IG, $7: 17+26$.

SUGUIO, K. \& MARTIN, L. (1978) Formações quaternārias marinhas do litoral paulista e sul fluminense. In: INTERNATIONAL SYMPOSIUM ON COASTAL EVOLUTION IN THE QUATERNARY, São Paulo, 1978. "Spe cial publication. no 1. São Paulo, IGCP Project 61/IGUSP/SBG.55p. 
SUGUIO, K. \& MUSSA, D. (1978) Madeiras fösseis dos aluviões antigos do Rio Tietê, são paulo. Boletim IG, 9: 25-45.

SUGUIO, K. \& TAKAHASHI, L.J. (1970) Estudo dos aluviões antigos dos rios Pinheiros e Tietê, SP. Anais da Academia : Brasileira de ciências, $42(3): 555-570$.

TAYLOR, T.N. (1981) Paleobotany. An Introduction to Fossil plant Biology. New York, Mcgraw-Hill Book Company, 589p.

TOLENTINO, M. (1965) Algumas considerações sobre um carvão ! da Bacia de são Paulo. Publ. Esc. Eng.S.Carlos, USP, 135: 29-33, (Geol. no 13).

TROLL, W. (1938) Vergleichende Morphologie der hohern Pflanzen. $1(2)$. Berlin, Borntraeger.

MROPPMAIR, H. (1989) Biogeografia e meio ambiente. 3.ed. Edição do autor, $258 \mathrm{p}$.

TRYON, R.M. \& TRYON, A.F. (1982) Ferns and allied plants. New York, Springer-Verlag, 857p.

VESPUCCI, J.B.O. (1984) Sistemas deposicionais e evolução tectono-sedimentax da Bacia de Taubaté, sp. São paulo, Universidade de são Paulo, 98p. (Tese de Mestrado - Instituto de Geociên cias). 
VICALVI. M.A. (1982) o primeiro registro de peixes fósseis na Formação Caçapava do Estado de são Paulo. Anais da Acadenia Brasileira de ciências, 54(2): 351-354.

WILLIS, J.C. (1966) A Dictionary of the rlowering plants and ferns. Cambridge, Cambridge University Press, $12.14 p$.

WHOLERS, A. (1.964) Cenozöjco. Boletim do Instituto Geogräfico e Geológico, 41: 147-164.

WHOLERS, A.; MEZZALTRA, S. \& SETZER, J. (1954) Geologia da fôlha de JundiaI. Estado de são Paulo. o I.G.G., 12(1/2):116-131.

WOLFE, J.A. (1969) Paleogene floras from the Gulf of Alaska region. U.S. Geol. Surv., open file report, $114 \mathrm{p}$.

WOLFE, J.A. (1971) Tertiary climatic fluctuations and methods of analysis of Tertiary floras. Palaeogeography, Palaeoclimatology, Palaeoecology, 9: 27-57.

WOLFE, J.A. (1972) An interpretation of Alaskan Tertiary floras. Chpt. 13. In: GRAHAM, A. (ed.). Floristics \& Paleofloristics of Asja \& Eastern North Fmerica. Amsterdam, Elsevier Pub.Co. p. $2.10-233$.

WOIFE, J.A. (1978) A paleobotánical interpretation of Tertiary cli. mates in the Northern Hemisphere. American Scientist, 66: 694 703. 
WOLEE, J.A. (1981) Palecclimatic significance of the oligocene and Neogene floras of northwestern United States. In: NIKLAS, K.J. (ed.). Paleobotiny, Paleoecology, irand Evolution. New York, Fraeger, v.2, p. 79-101.

WOIJEE, J.A. \& UPCHURCH JR, G.R. (1987) North American nonmarine climates and vegetation during the sate Cretaceous. Palaeogeography, palaeoclimatology, palaeoecology, 61: 33-77. 
ESTAMPAS 
Fig. 1 - Ocotea pulchelliformis - mostrando detalhes da nervaÇão e numerosas estruturas circulares de tamanho redu zido; espēcime GP/3E-5134 (holótipo).

Figs. 2,3 - Luehea divaricatiformis; 2 - mostxando a margem serrada, as três nervuras primärias divergindo da base do limbo, as nervuras secundárias sub-paralelas e as maxcas de possiveis galhas produzidas por insetos; es pécime GP/3T-1823 (holötipo); 3 - mostrando detalhes da nervação; espēcime GP/3E-4804.

Fig. 4 - Casearia serrata - mostrando a margem serxada e as nervuras primärias e secundārias; espēcime GP/3T-1811 (holōtipo).

Figs.5,6 - Machaerium piranii - mostrando detalhes da nervação e marcas de possiveis galhas, produzidas por fungos ou insetos, distribuidas irregularmente pelo limbo; espécimes GP/3E-5238a, $-5238 b$ (parte e contraparte). 
ESTAMPA I
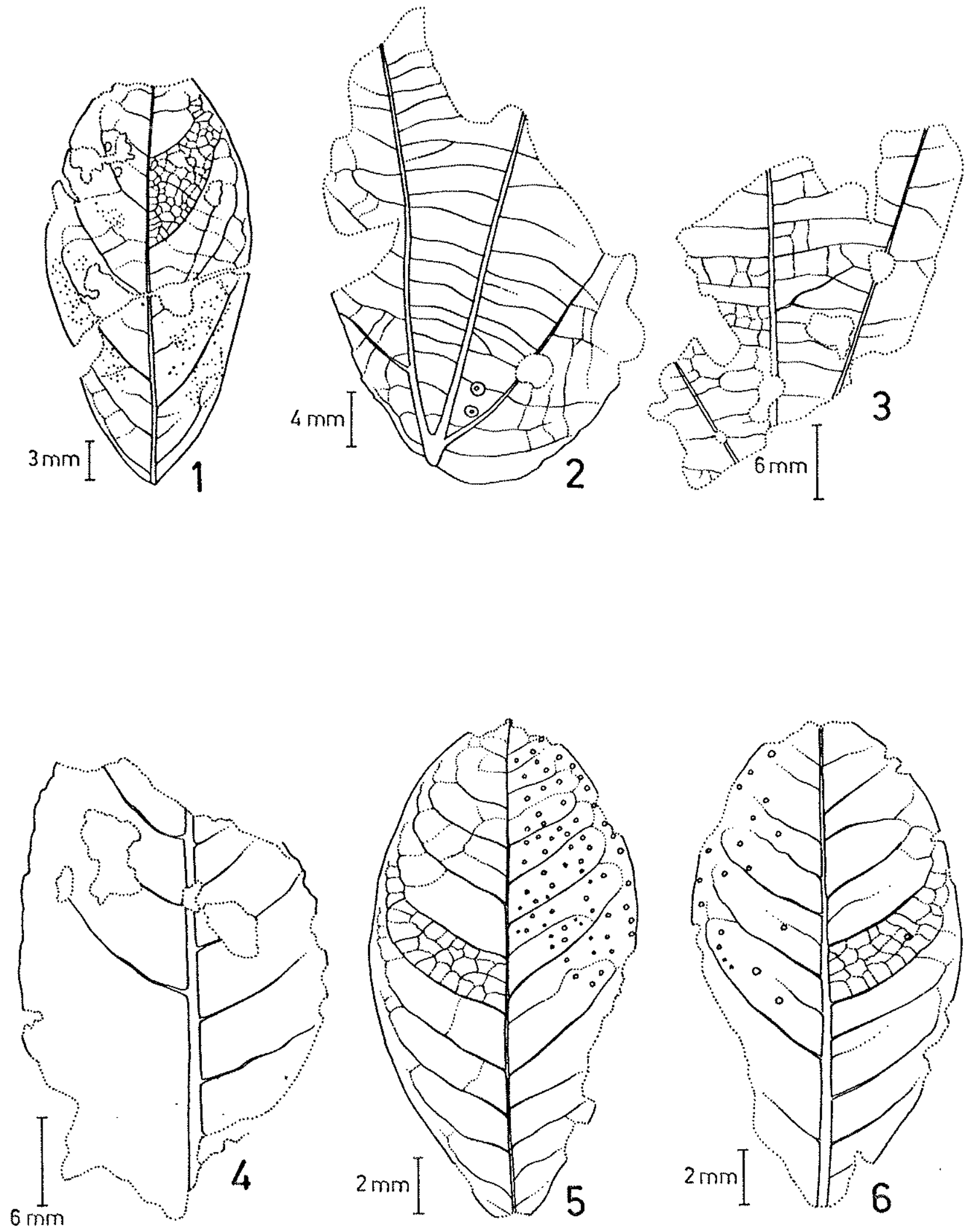
Figs. 1,2 - Machaerium piranii; 1 - mostrando detalhes da nervação e marcas de possiveis galhas; espécime GP/3E-5109; 2 mostrando o āpice emarginado e detalhes da nervação, es pécime GP/3E-5091 (holótipo).

H'ig. 3 - Schizolobium inaequizaterum - mostrando a base assimé trica e a nervura mediana ligeiramente arqueada; espéci me GP/3T-1812 (holótipo).

Fig. 4 - Cassia rosleri - mostrando a base assimétrica e deta thes da nervação; espécime GP/3E-5112 (holótipo).

Wigs.5,6 - Psidium pauzense; 5 - mostrando detalhes da nexvação e numerosas glândulas diminutas distribuídas por todo limbo; espécime GP/3E-5240;6 - destacando a presença de uma nitida nervura coletora; espécime GP/3T-1817 (holótipo). 

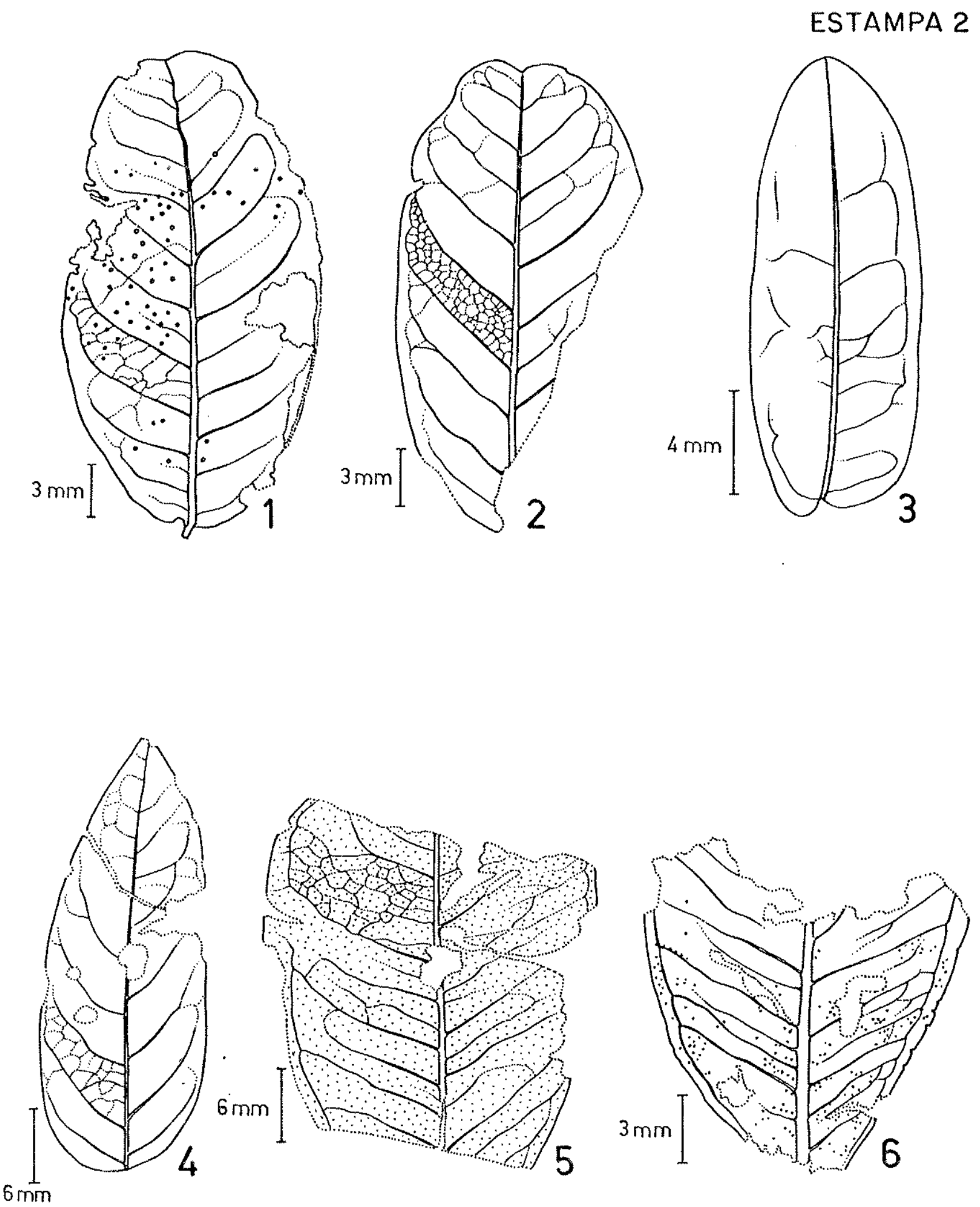
Figstl-4 - Myrcia cf. rostrataformis; 1 - mostrando a base atenuada, a nervação broquidódroma e as glândulas diminú tas; espécime GP/3T-1815; 2 - mostrando o contorno 1 i geiramente falciforme, o pecíolo preservado e a marca de uma possivel galha provocada por inseto; espécime GP/3E-5079a; 3 - mostrando o contorno ligeiramente falciforme; espécime GP/3E -5082; 4 - porção distal mostrando a nervação broquidödroma, com destaque para a nervura coletora; espēcime GP/3T-1814.

Fig. 5 - Bertolonia coimbrai - mostrando as cinco nervuras primärias divergindo da base do limbo e as nervuras secundärias sub-paralelas; espécime GP/3E-5239 (holötipo).

Figs.6,6a.- Rhamniphyzlum caseariformis; 6 - mostrando o padrão geral de nervação; 6 a - mostrando detalhe do retícu10; espëcime GP/3m-1810 (holötipo).

Fig. 7 - Aquifoliphyzzum izicioides - mostrando a margem den teada e detalhes da nervação; espécime GP/3T-1810 (ho lötipo) 
ESTAMPA 3
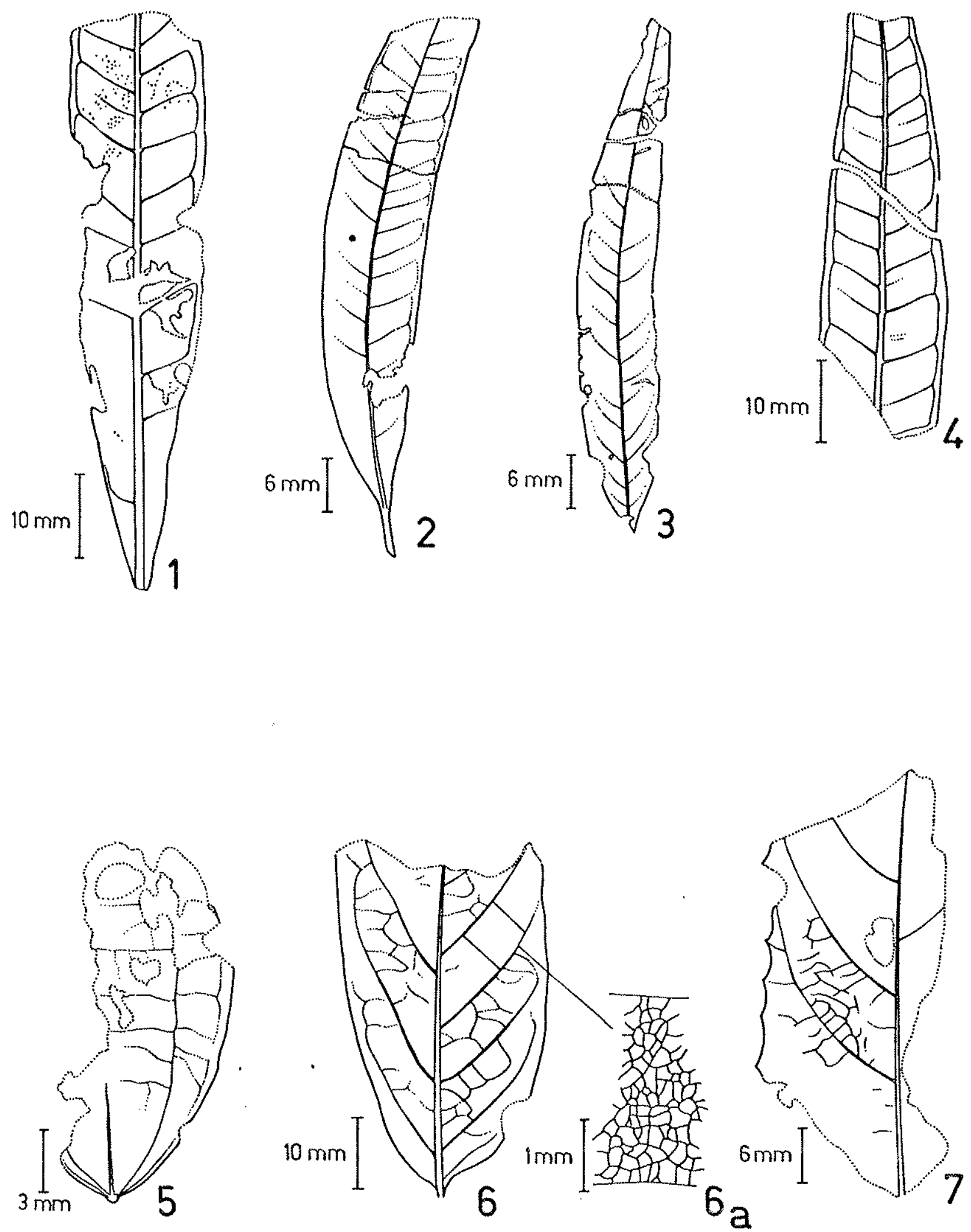


\section{ESTRMPA 4}

Figs.1-4 - Byrsonima bullata; 1 - mostrando um espëcime muito in completo; espécime GP/3E-5272; 2 - mostrando detalhes da nervação; espécime GP/3T-1824; 3 - mostrando o aspecto geral da folha; espécime GP/3T-1813 (holötipo); 4 - mostrando detalhes da nervação; espēcime GP/3E-5241. 

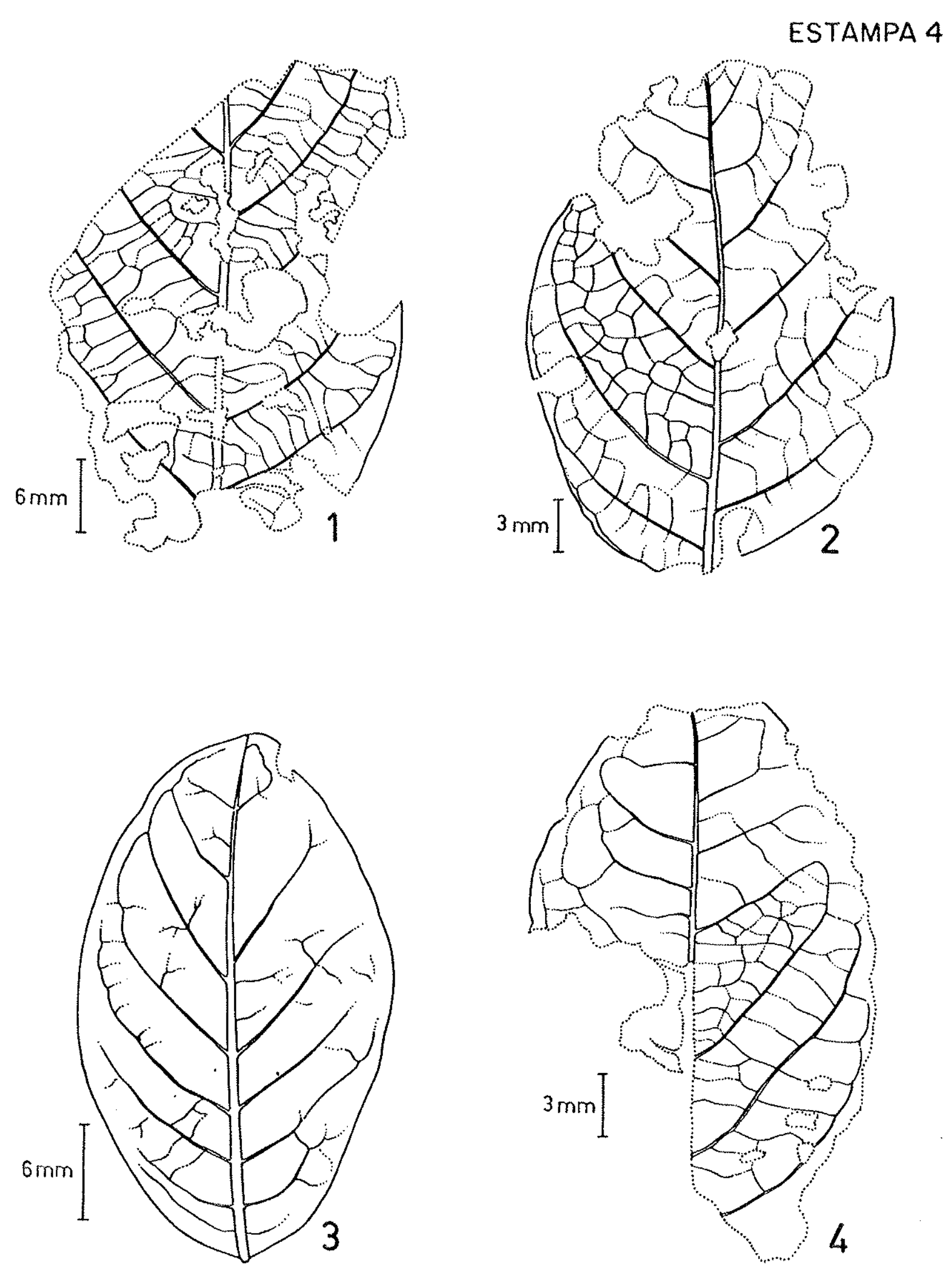
Fig. 1 - Zanthoxyzum glanduliferum - mostrando a nervação eu camptódroma e as glândulas dispersas pelo limbo; espé cime GP/3T-1821 (holötipo).

Figs.2-5 - Serjania itaquaquecetubensis; 2-espēcime muito frag mentado mostrando a nervação craspedódroma; espécime $\mathrm{GP} / 3 \mathrm{E}-5236 ; 3$ - mostrando a margem irregularmente ser rada e a nervação craspedōdroma; espécie GP/3T-1820 (holótipo); 4,5 - mostrando a margem irregularmente serrada e detalhes da nervação; espëcimes GP/3E-5238a, $-5238 \mathrm{~b}$ (parte e contraparte).

Pig. 6 - Serjania Zancifolia - mostrando o folíolo lanceolado, com margem irregularmente serrada e nervação craspe aródoma; espécie GP/3T-1819 (hotótipo). 

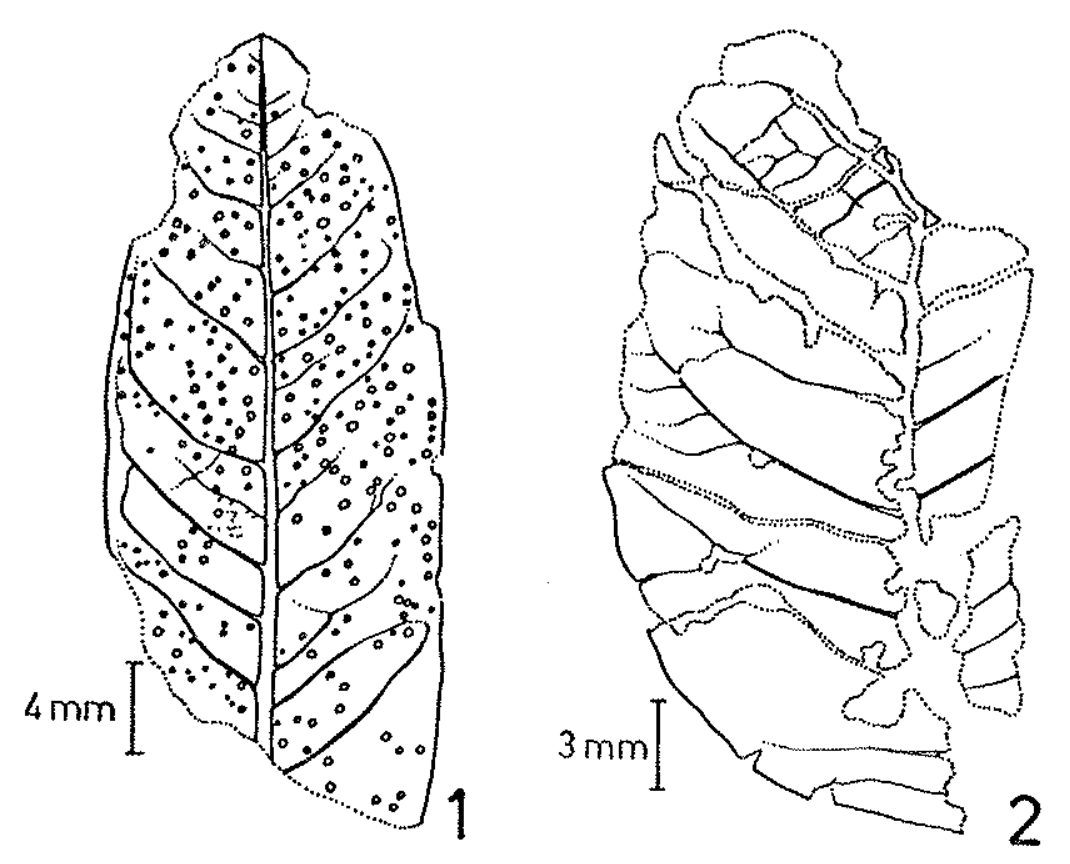

ESTAMPA 5
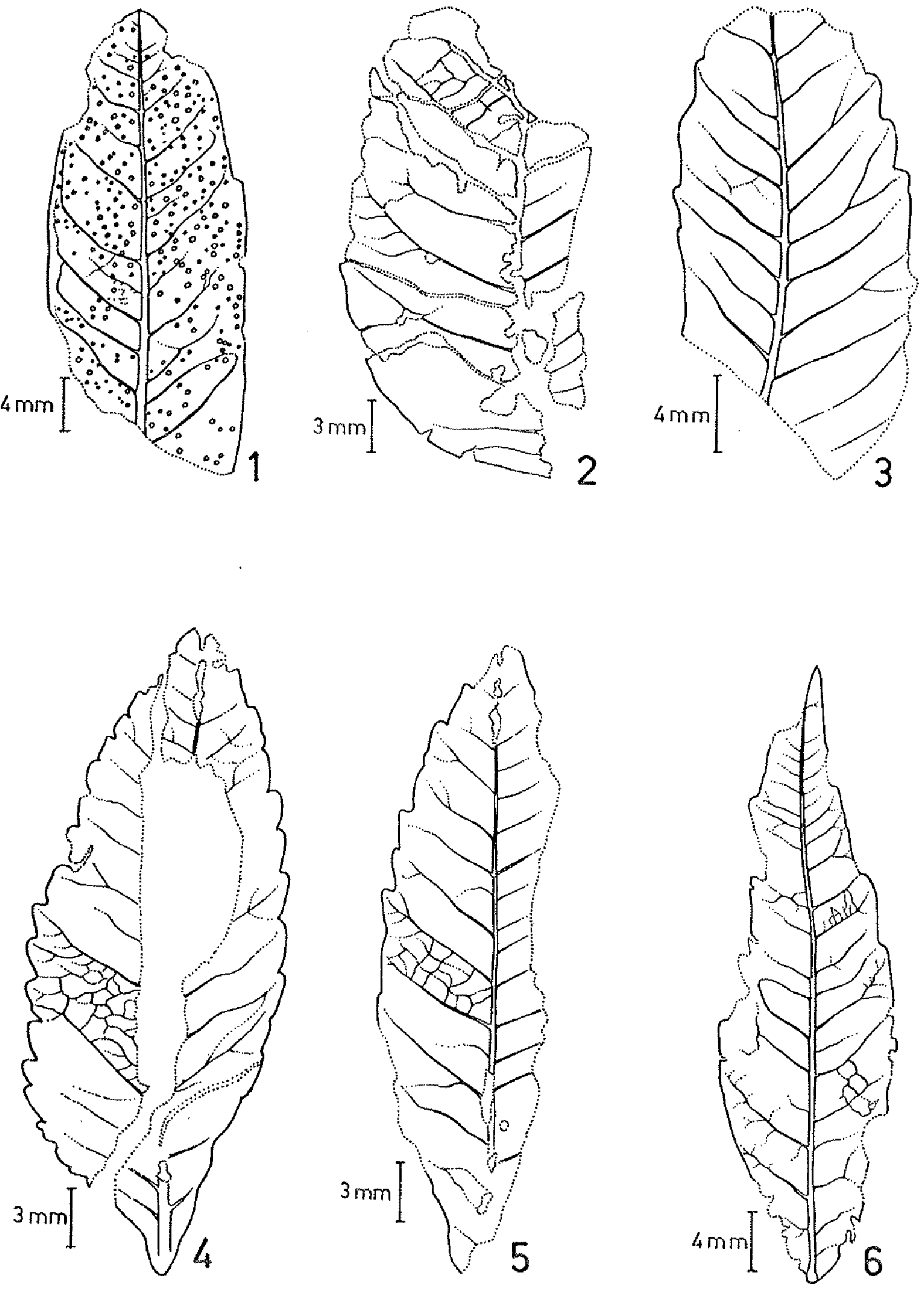


\section{ESTAMPA 6}

Fig. 1 - Echinodorus rossiae - mostrando as nervuras primárias divergindo da base do limbo, e detalhe das nervuras secundārias sub-paralelas; espécime GP/3E-5152 (holótipo)

Fig. 2 - Tocoyena riccominii - mostrando o contorno obovado e a nervação broquidödroma; espëcime GP/3E-5133 (holóti po).

Fig. 3 - Monstera marginata - mostrando a nervação camptódro ma; espëcime GP/3T-1809 (holötipo).

Figs.4,5 - Semente (?); 4 - seção longitudinal mostrando a provāvel ärea micropilax; 5 - seção transversal; amos tra $G P / 3 T-1826$.

Figs.6-8 - Fruto (?); 6 - vista frontal mostrando dois "sacos"; 7 - vista lateral mostrando dois "sacos"; 8 - seção longitudinal do "saco" mostrando vários löculos intex nos; espécime GP/3T-1827. 
ESTAMPA 6
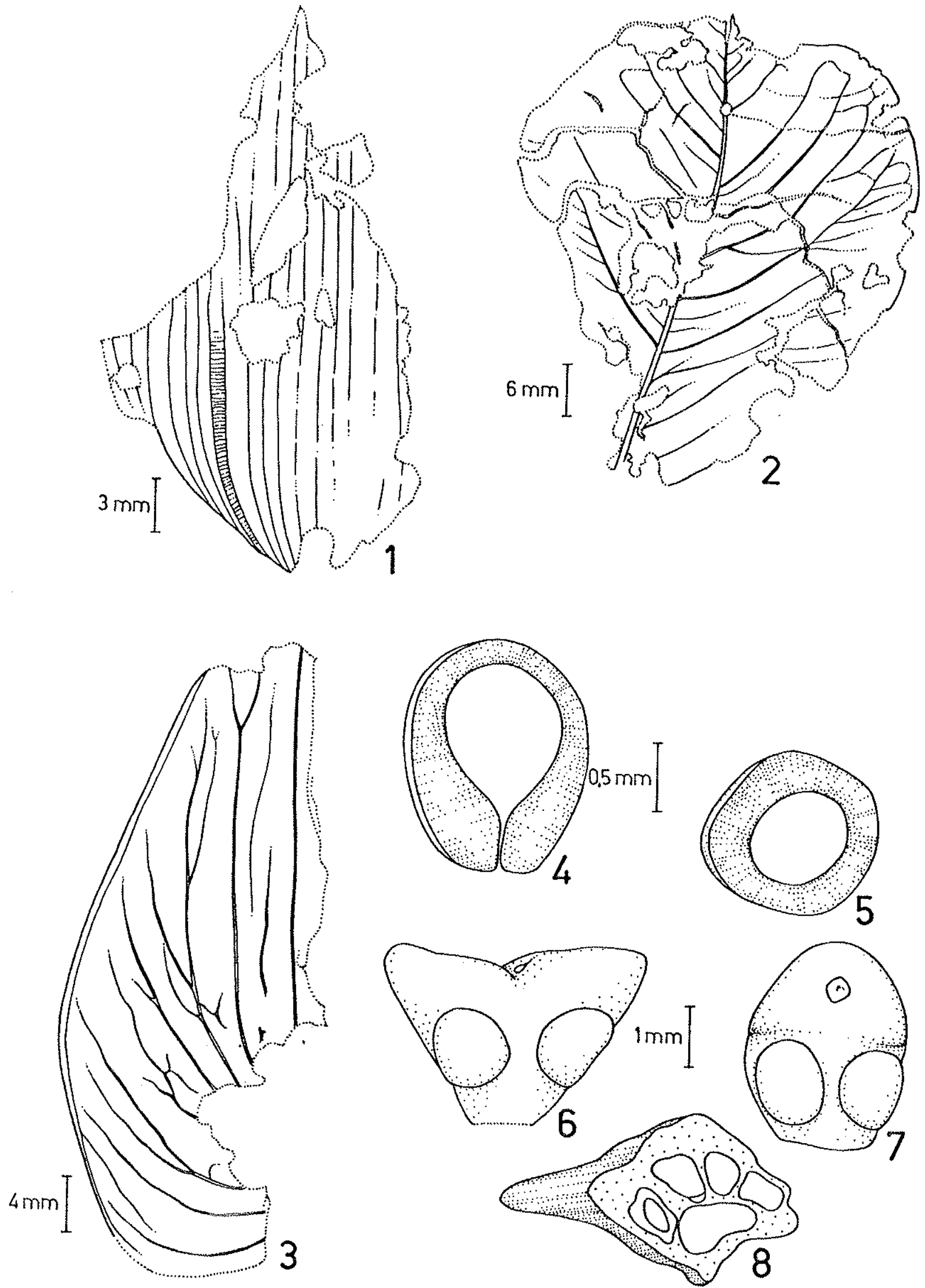


\section{ESTAMPA 7}

Figs. 1-4 - Isotachis simonesi; 1-3 - mostrando fragmentos de di versos espēcimes associados com prováveis caulídios de briófitas talosas; 4 - mostrando um caulídio simples com duas sëries de filídios; espécime GP/3E-5189 (holötipo). 

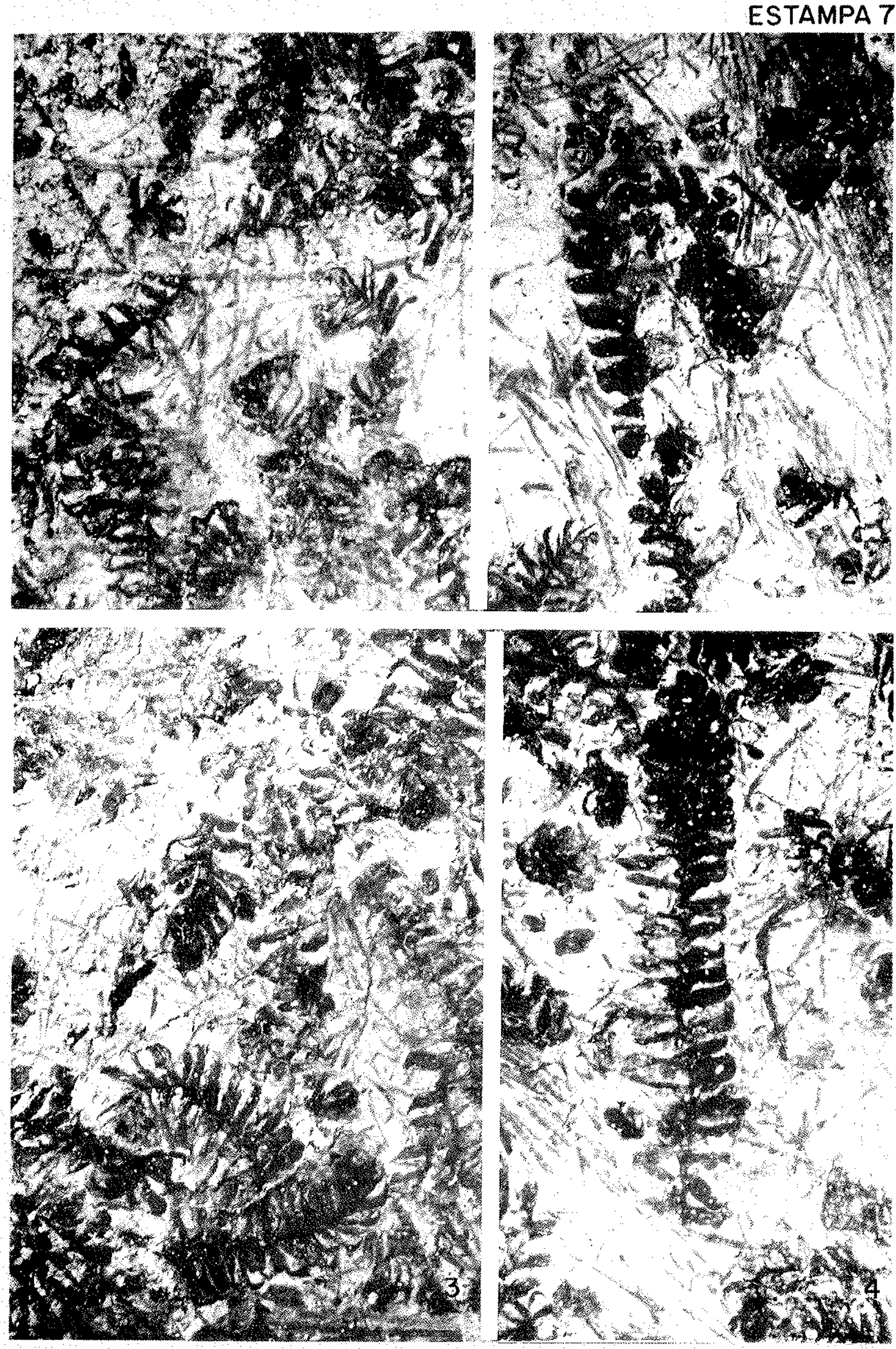


\section{ESIIAMIPA 8}

Figs. 1-3 - Lindsaea pradoi; 1,2 - mostrando pinas sub-trapeziformes; espécimes GP/3E-5217a, -5217b (parte e contra parte); 3 - mostrando o indúsio semi-lunar crenulado; espécime GP/3E -5217a.

Figs. 4,5 - Echinodorus rossiae; 4-mostrando as nervuras primárias divergindo da base da folha e as nervuras secundá rias sub-paralelas; espécime GP/3E-5152 (holótipo); 5 - mostrando um fragmento da folha; espécime GP/3E $-5163$. 
ESTAMPA 8
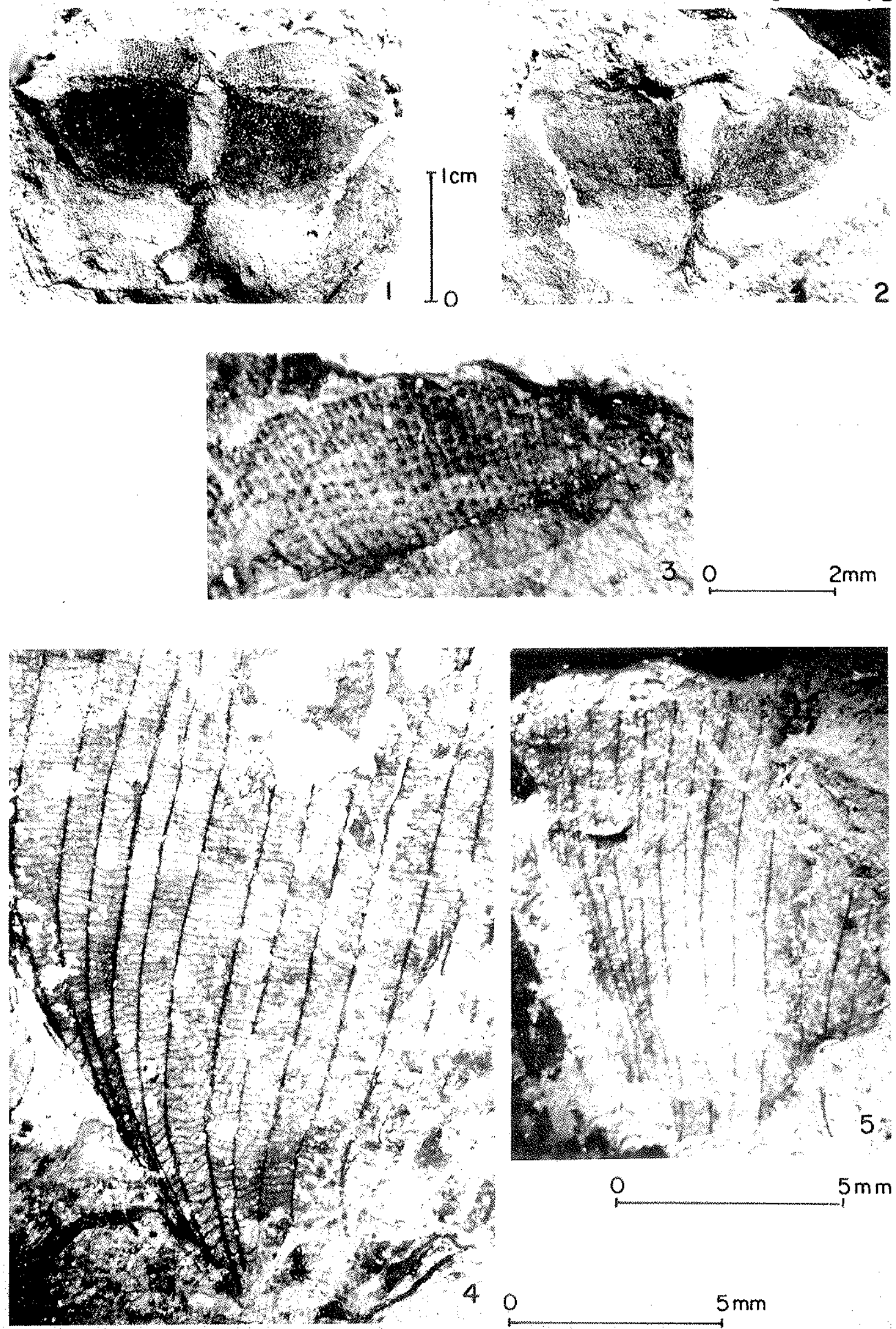
Fig. 1 - Schizolobium inaequilaterum - mostrando o aspecto geral do foliolo e a base assimétrica; espëcime GP/3T -1812 (holótipo).

Fig. 2 - Schizolobium parahyba - para comparação com S. inaequilaterum.

IFïg. 3 - Ocotea pulchelliformis - mostrando o aspecto geral da folha; espécime GP/3E-5134 (holötipo).

Fig. 4 - ocotea pulchelza - para comparação com o.pulchelli fornis.

Fig. 5 - Luehea divaricatiformis - mostrando as trés nervu ras primärias e as nervuras secundárias sub-parale las; espëcime GP/3E-4804.

Fïg. 6 - Wuehea divaricata -para comparação com L.divaricatiformis. 
ESTAMPA 9
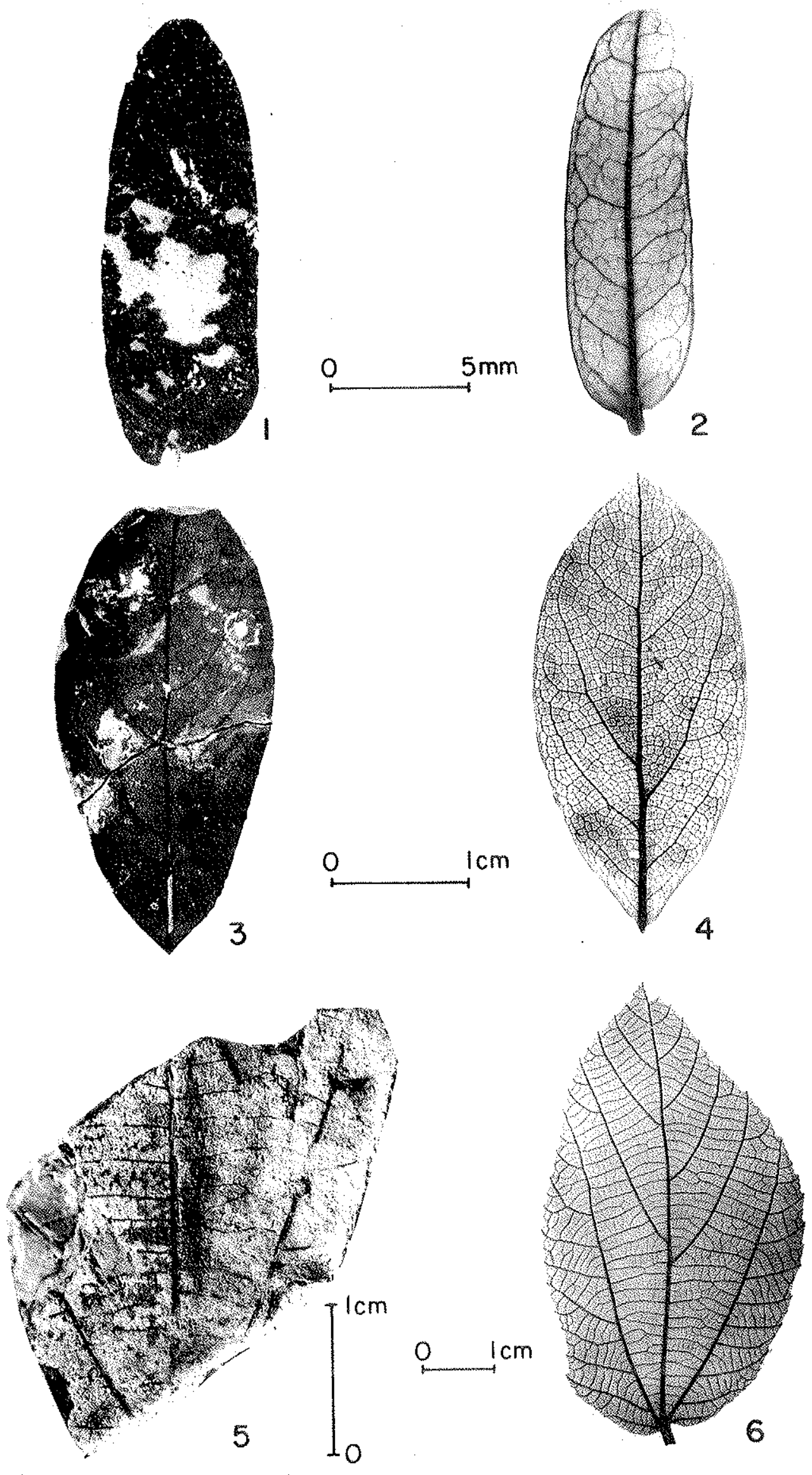
ESTAMPA 10

Figs. 1-3 - Piptadenia tertiaria; 1 - folíolos (foliólulos?) falcados isolados; espēcime GP/3E-5122; 2 - fragmento de folha mostrando folíolos (foliólulos?) li neares falcados; espécime GP/3E-5130 (holötipo);3folíolos (foliólulos?) isolados, espécime GP/3E 5124. 


\section{ESTAMPA 10}

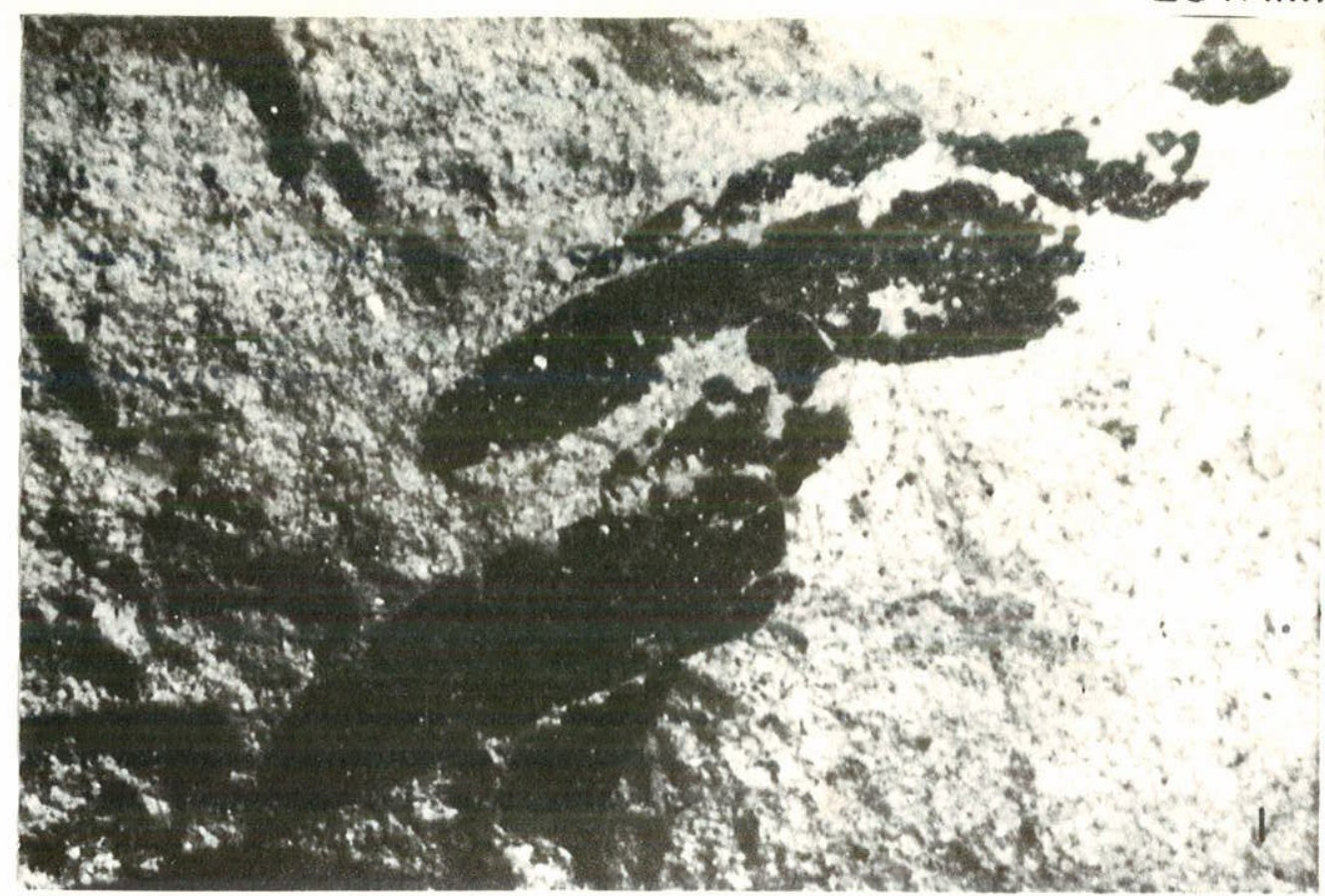

P $\mathrm{Icm}$
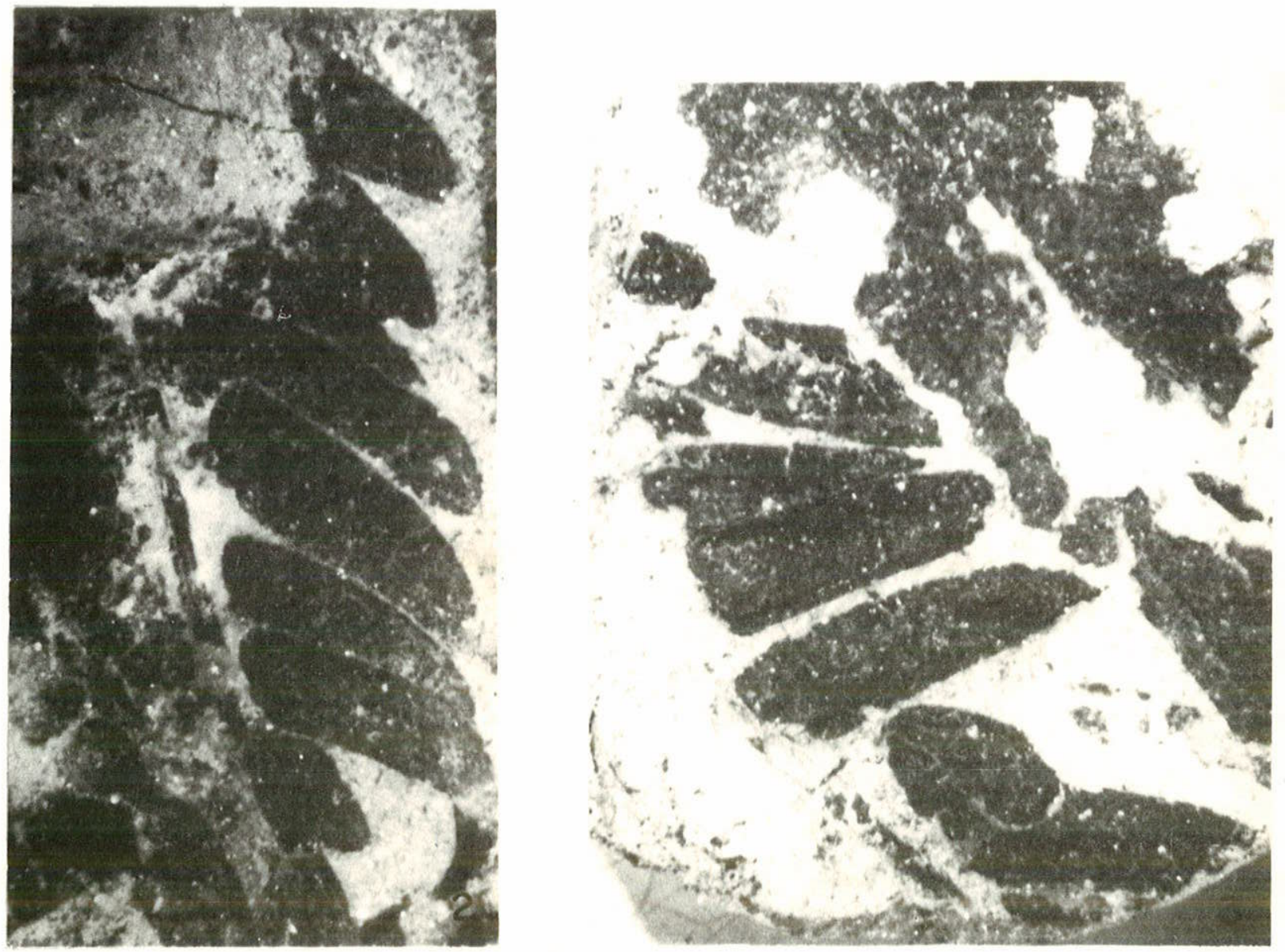
Figs. 1-4 - Cassia rosleri; 1 - mostrando o aspecto geral da folha; 2 - mostrando marcas de possíveis galhas provocadas por insetos; 3,4 - detalhes das possíveis gaIhas; espécime GP/3E-5112 (holótipo). 

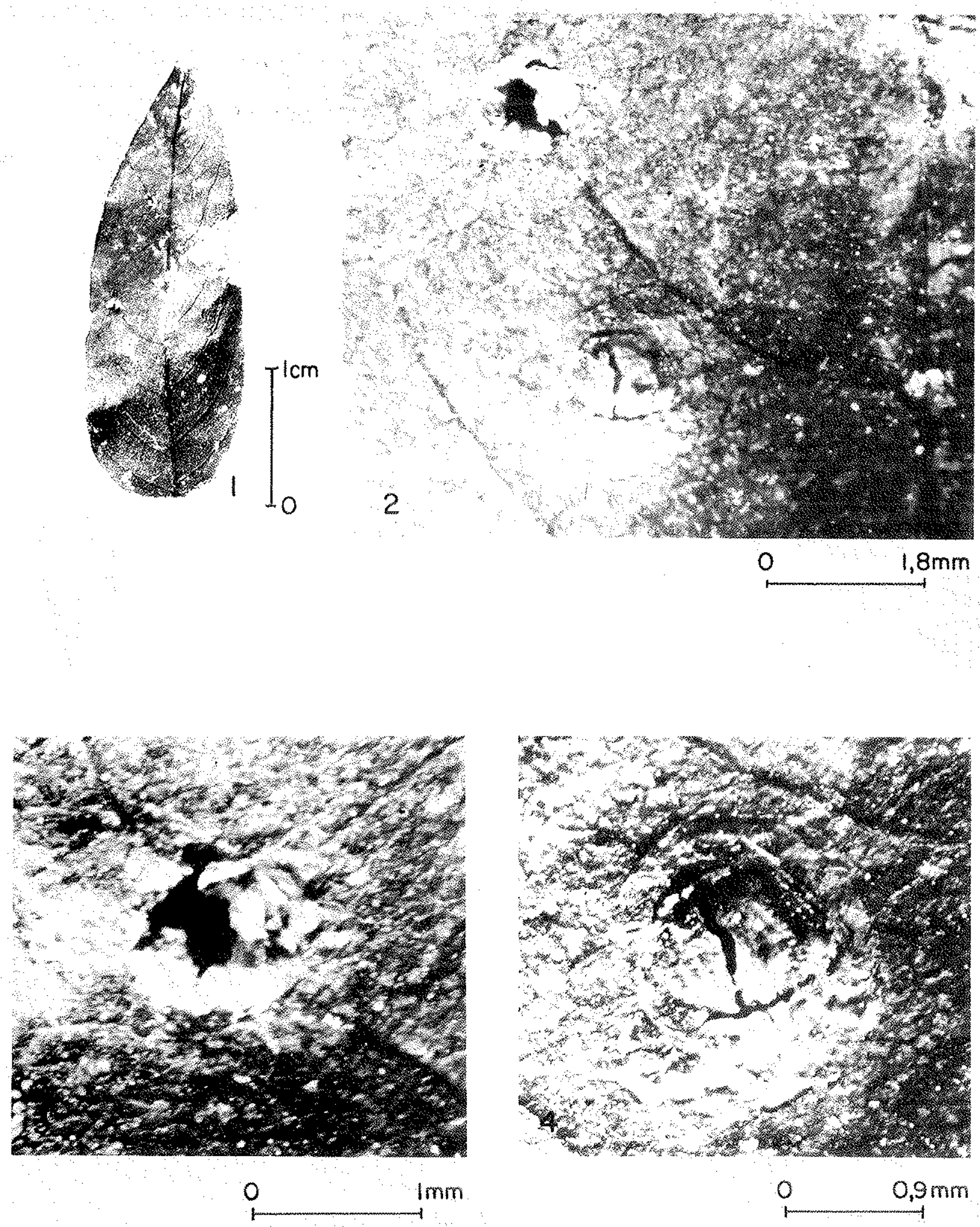
Figs. 1-4 - Machaerium piranii; 1 - fragmento da porção superior do foliolo, mostrando o ápice emarginado e marcas de possíveis galhas; espēcime GP/3E-5043; 2 - mostran do o âpice emarginado e a nervação broquidódroma; es pécime GP/3E-5091 (holótipo); 3 - mostrando o aspecto geral do follolo e marcas de possiveis galhas;es pëcime GP/3E-5109; 4 - mostrando a nervação broquidódroma e marcas de possiveis galhas; espëcime GP / $3 \mathrm{E}-5092$. 


$$
=1
$$


Figs. 1-3 - Sophora giuliettiae; 1 -mostrando detalhe do fruto; 2 - mostrando o aspecto geral do fruto; 3 - desenho esquemätico do fruto; espëcime GP/3E-5218 (holótipo). 

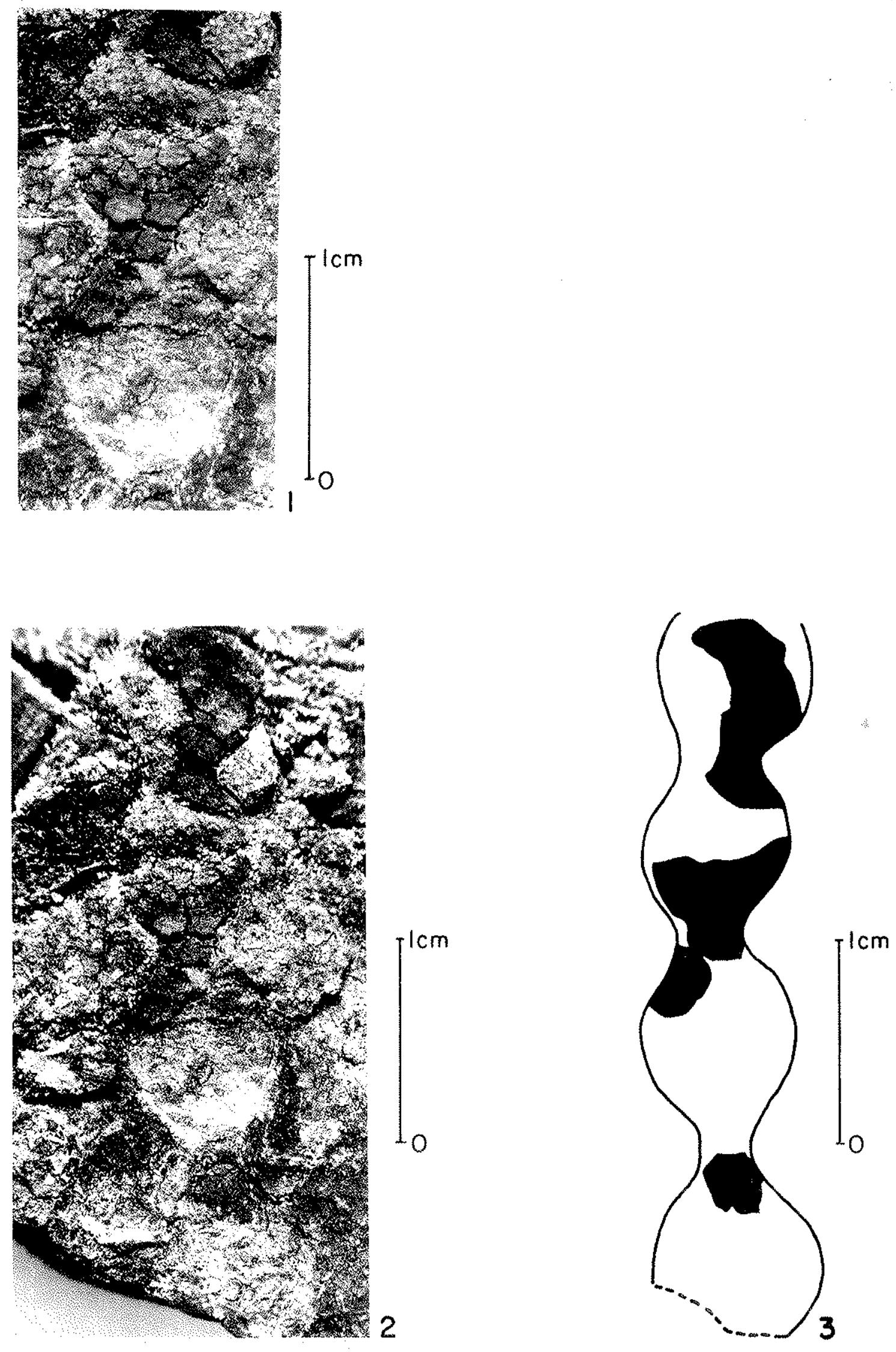


\section{ESTAMPA 14}

Fig. 1 - Myreia rostrata - para comparação com M. cf. rostrataformis.

Pigs. 2-8 - Myrcia cf. rostrataformis - diversos espécimes mostrando a variação existente no formato da folha; espëcimes GP/3E-5081, $-5086,-5079 a,-5082,-5084$, $-5076, G P / 3 T-1814$. 


$$
\frac{110}{1110}
$$


Figs. 1-4 - Byrsonima bullata; 1 - mostrando o contorno eliptico da folha e a nervação broquidódroma; espécime GP/ 3T-1813 (holötipo); 2-4 - điversos espēcimes incom pletos mostrando detalhes da nervação; espëcimes GP/ $3 \mathrm{E}-5243,-5242, \mathrm{GP} / 3 \mathrm{~T}-1824$.

Fig. 5 - Psidium paulense - mostrando a nervação broquidödroma e diminutas glândulas distribuidas por todo o lim bo; espëcime GP/3E-5240.

Eng - 6 - Byrsonima bullata - amostra mostrando dois espécimes incompletos com nervação bastante nitida; amostra GP/ $3 E-524]$. 

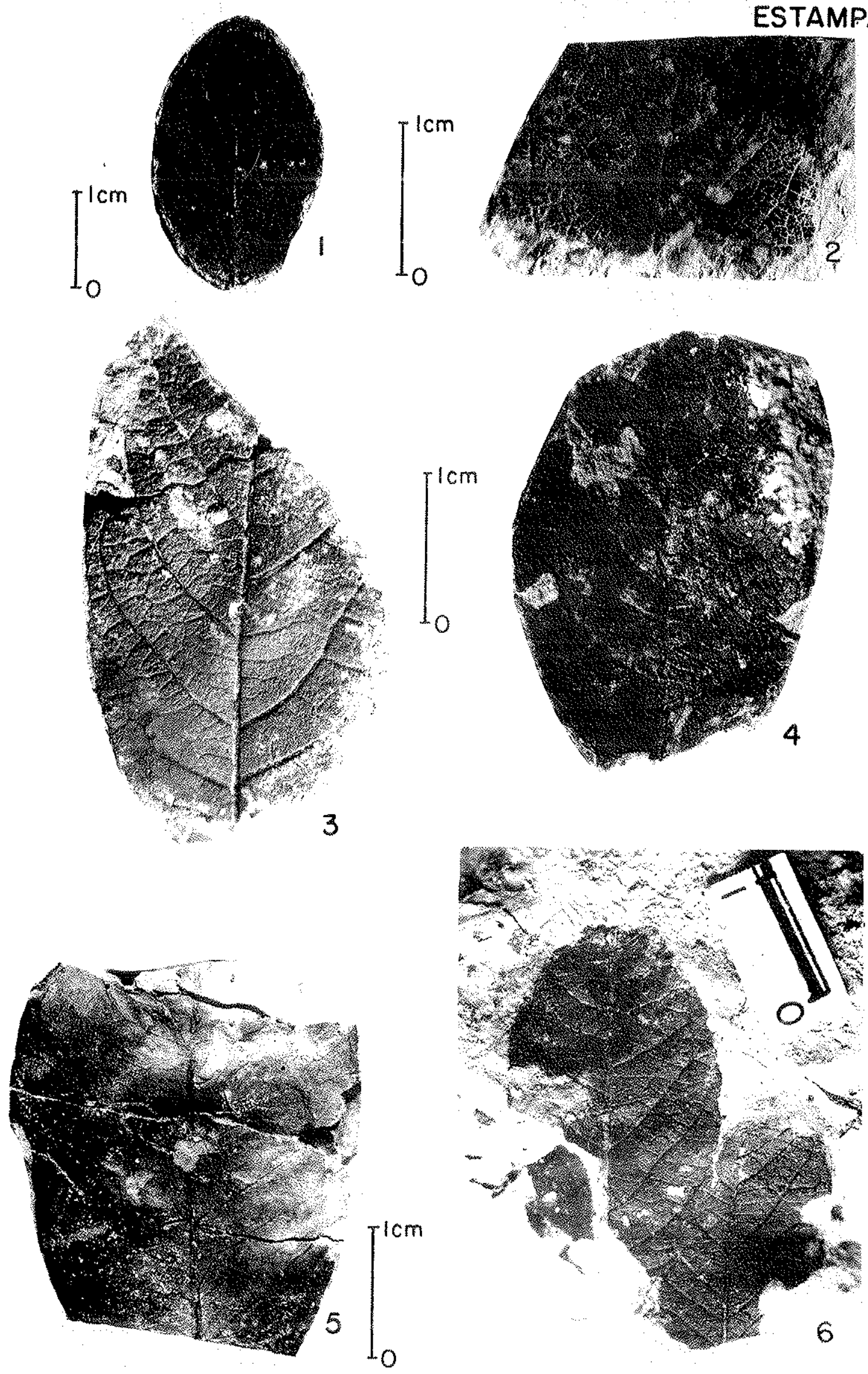


\section{ESSTAMIPA 16}

Fig. 1 - Tocoyena riccominit - mastrando o contorno obovado e a nervação broquidōdroma; espēcime GP/3E-5133 tho1ótipo)

Wig. 2 - Toeoyena sp. - para comparação com T. riceominii.

Figs.3,4 - Serjania itaquaquecetubensis; 3 - mostrando a nerva ção craspedöđroma; espëcime GP/3E-5236; 4 - mostrando a margem irregularmente serrada e a nervação cras pedödroma; espëcime GP/3E-5238a.

Pïg. 5 - Serjania lancifotia - mostrando o contorno Ianceolado, a margem irregularmente serrada e a nervação cras pedödroma; espëcime GP/3E-4770. 
ESTAMPA 16
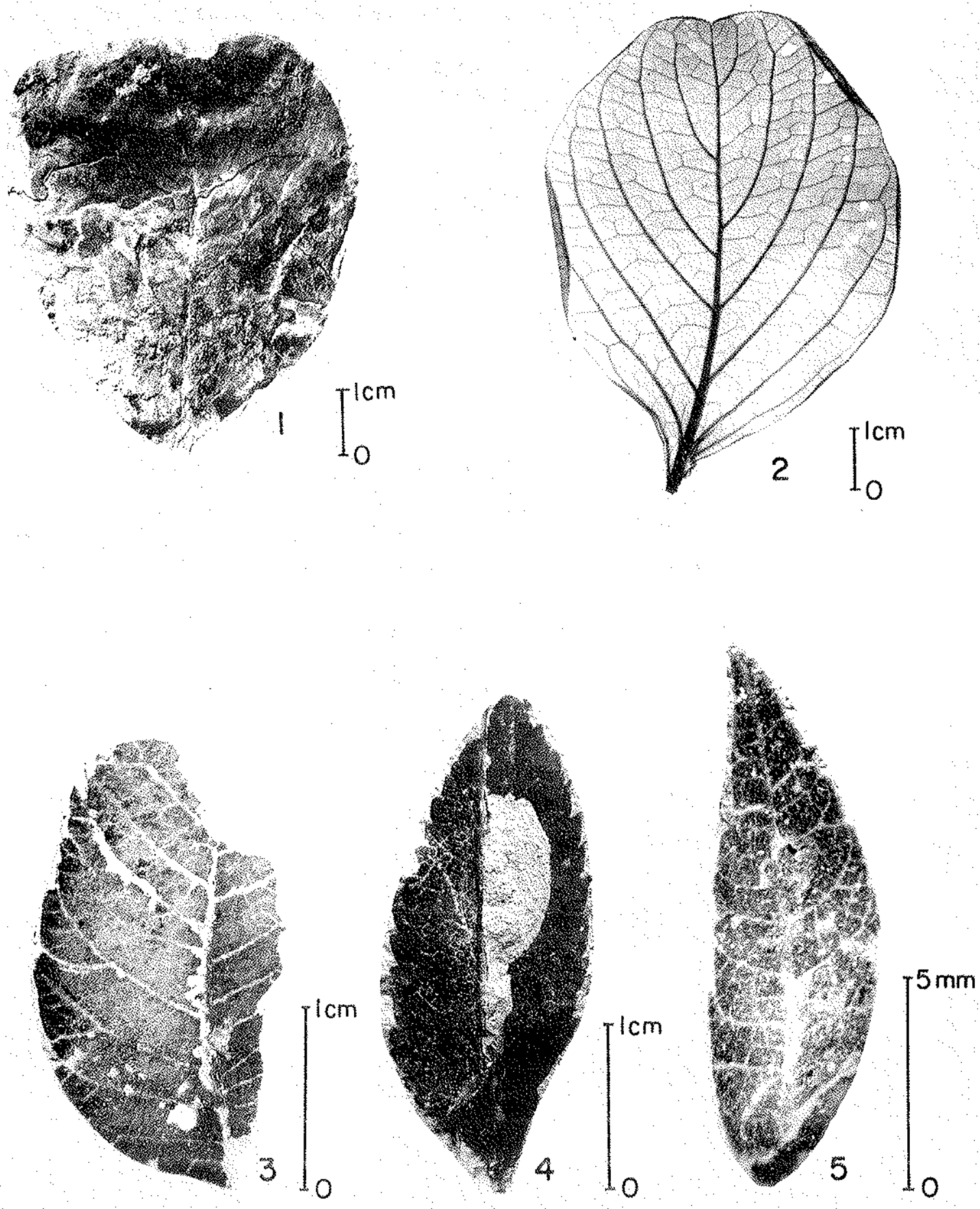
ESTAMPA 17

Figs. 1-6 - Semente (?); 1 - vista frontal; 2 - seção longitudinal mostrando a provável área micropilar; 3-6 aspecto geral de diversos espécimes; amostra GP/3T $-1830$. 
ESTAMPA 17
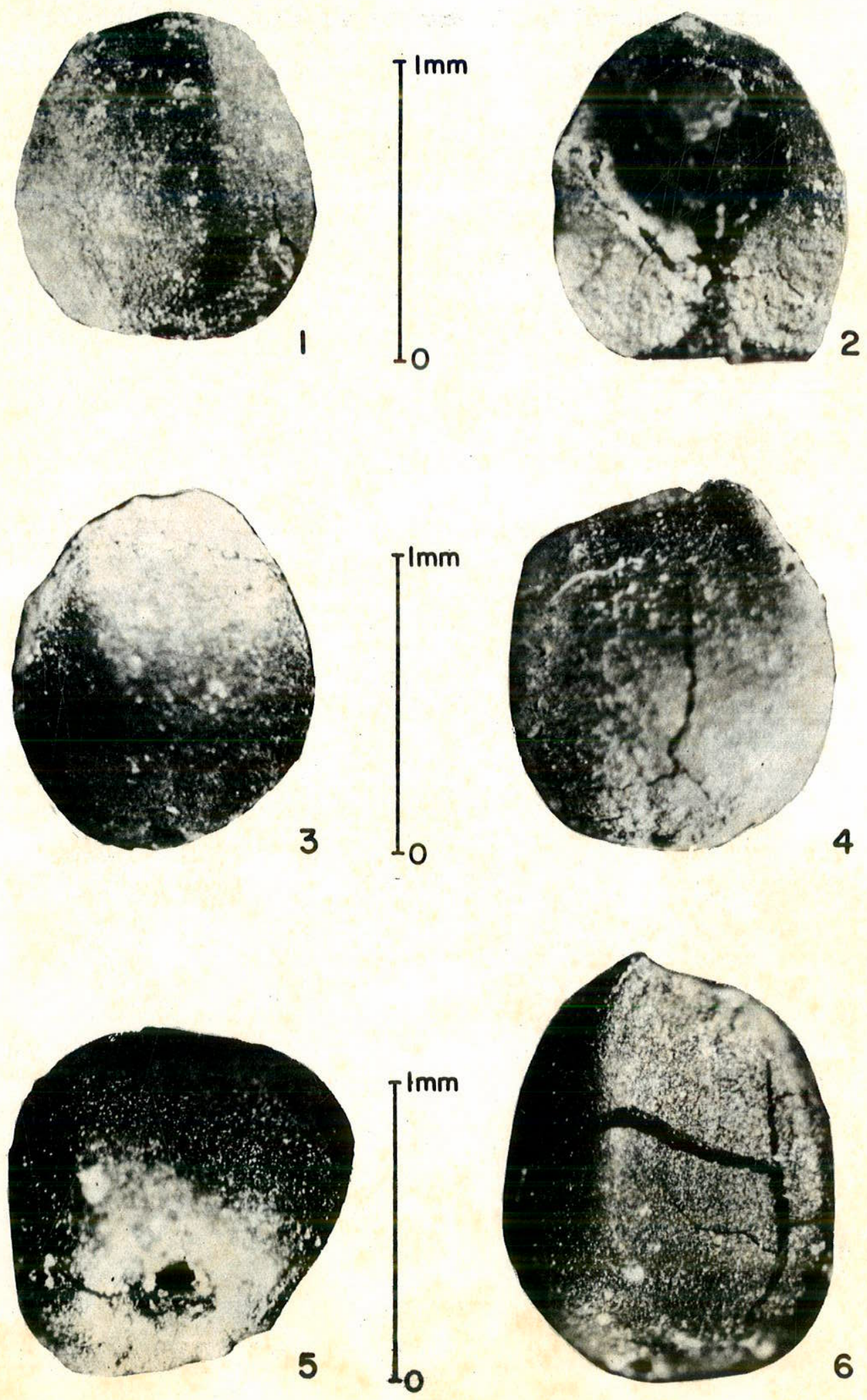
Figs. 1-8 - Frutos (?) - diversos espécimes em vistas variadas mostrando dois "sacos"; espécimes GP/3E-5219,-5220, $-5221,-5222$. 
ESTAMPA 18
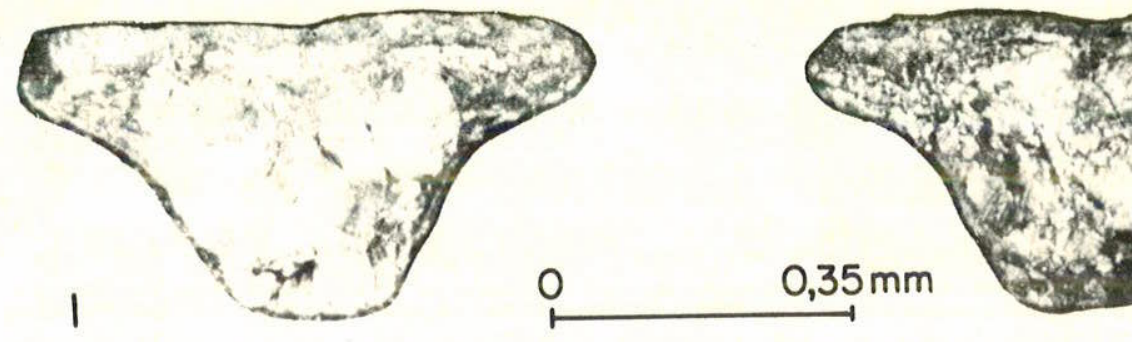

64 arations

(1)

$0,35 \mathrm{~mm} 2$
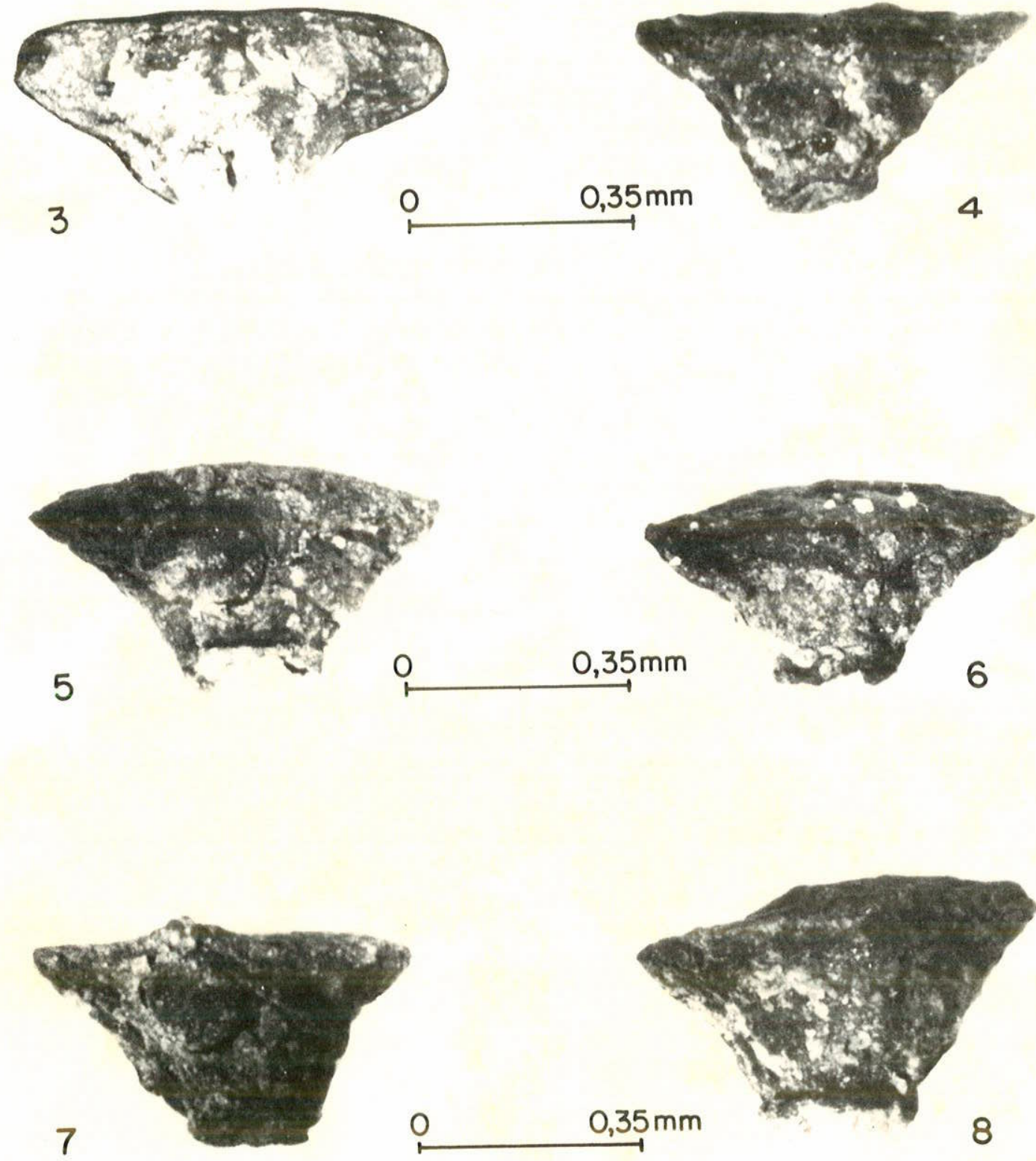

0

$0,35 \mathrm{~mm}$

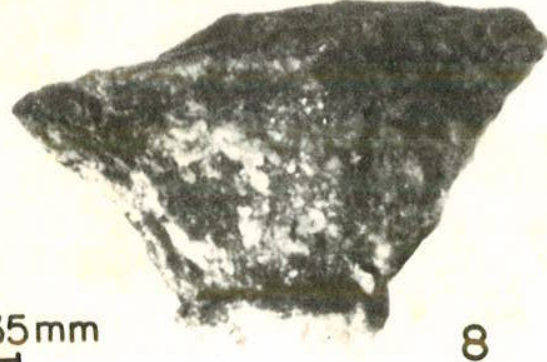


Figs. 1-6 - Estruturas reprodutivas (?) indeterminadas; espécimes GP/3E-5226, $-5223,-5230,-5227,-5228$. 
ESTAMPA 19
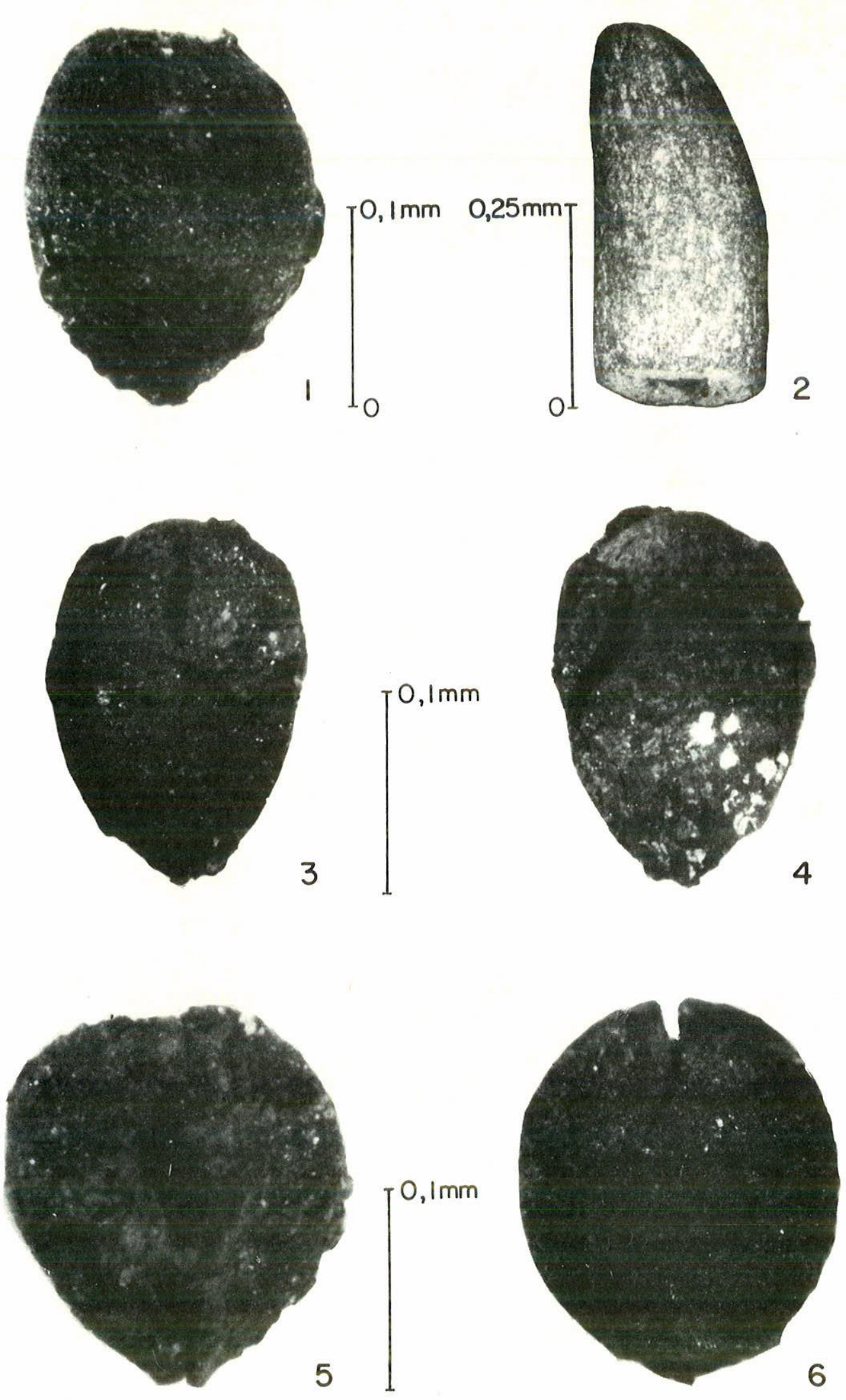


\section{APENDICE}

PRINCIPATS OCORRENCIAS DE RESTOS

VEGETAIS NO CENOZOICO BRASILEIRO

$$
\text { Folhas } \hat{\varphi}
$$

Troncos

Frutos e/ou sementes 0 


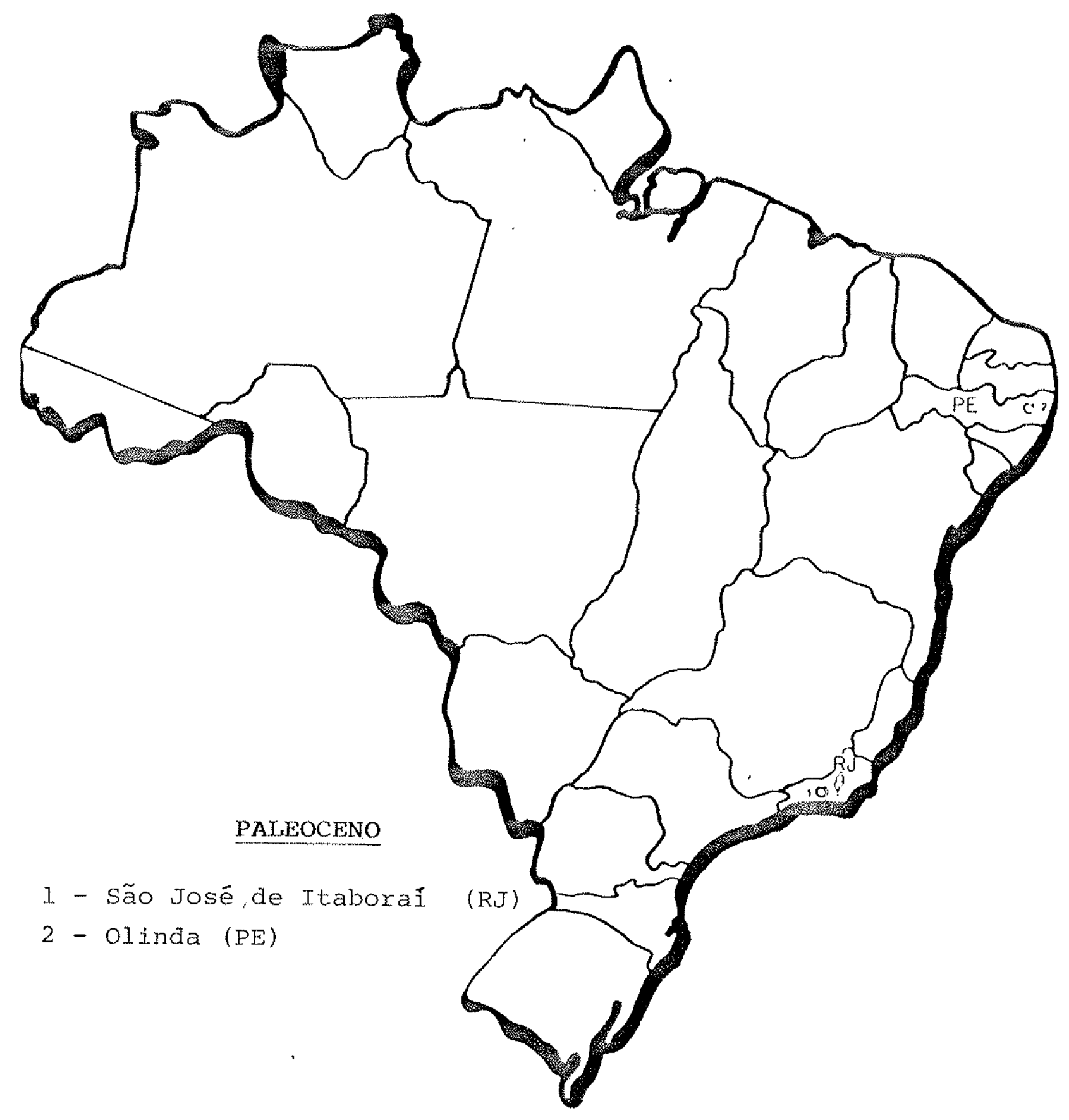




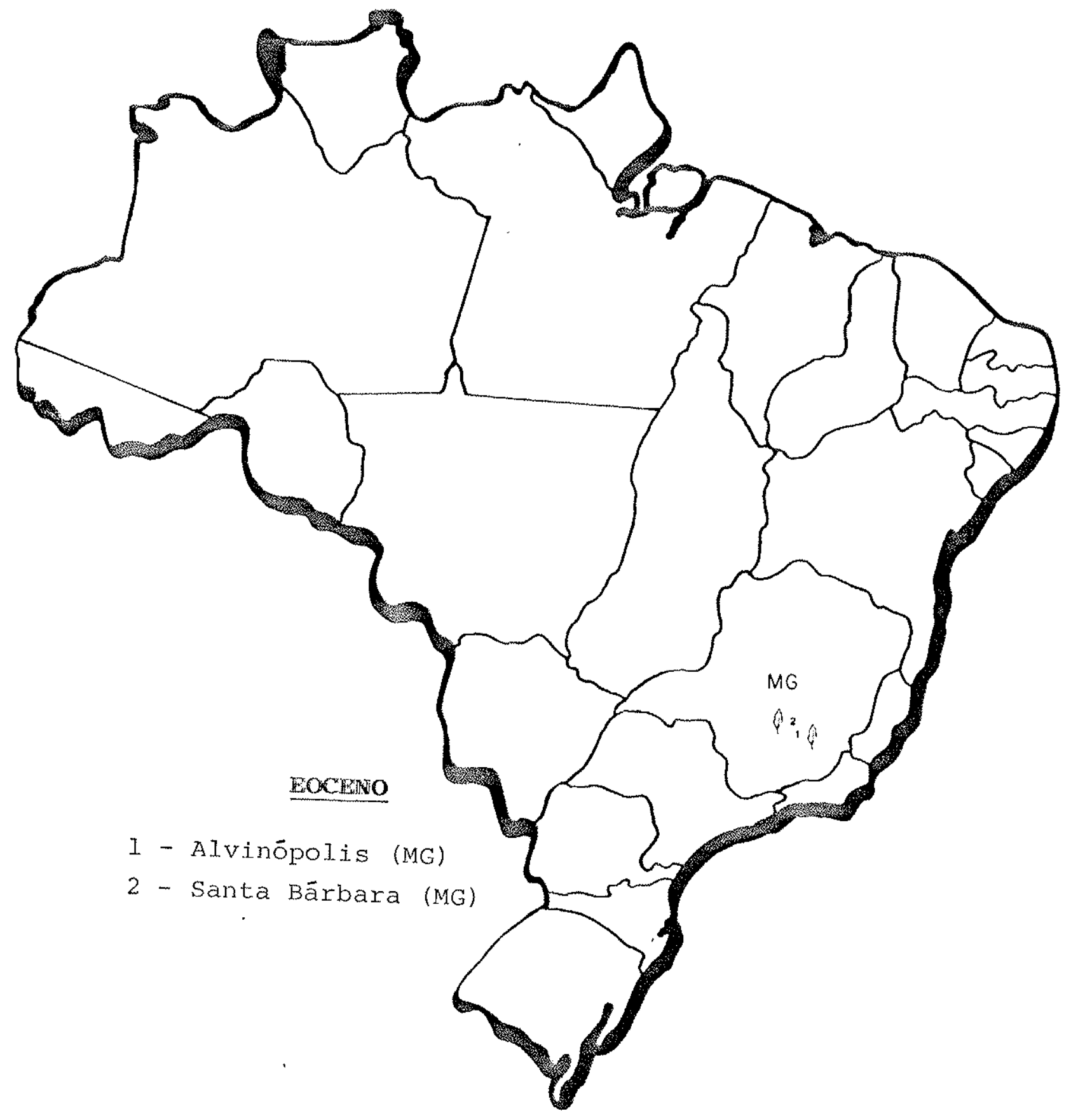




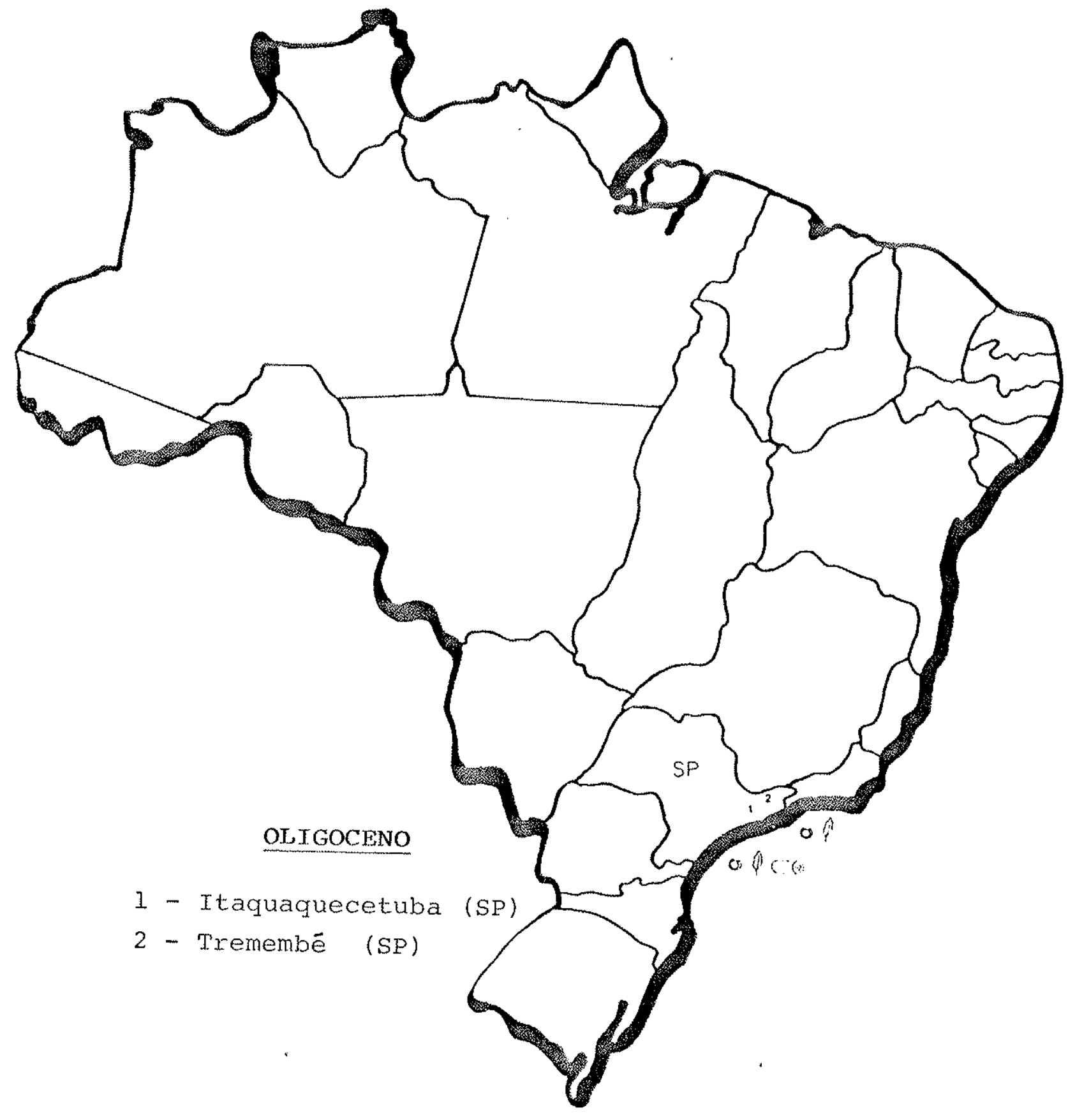




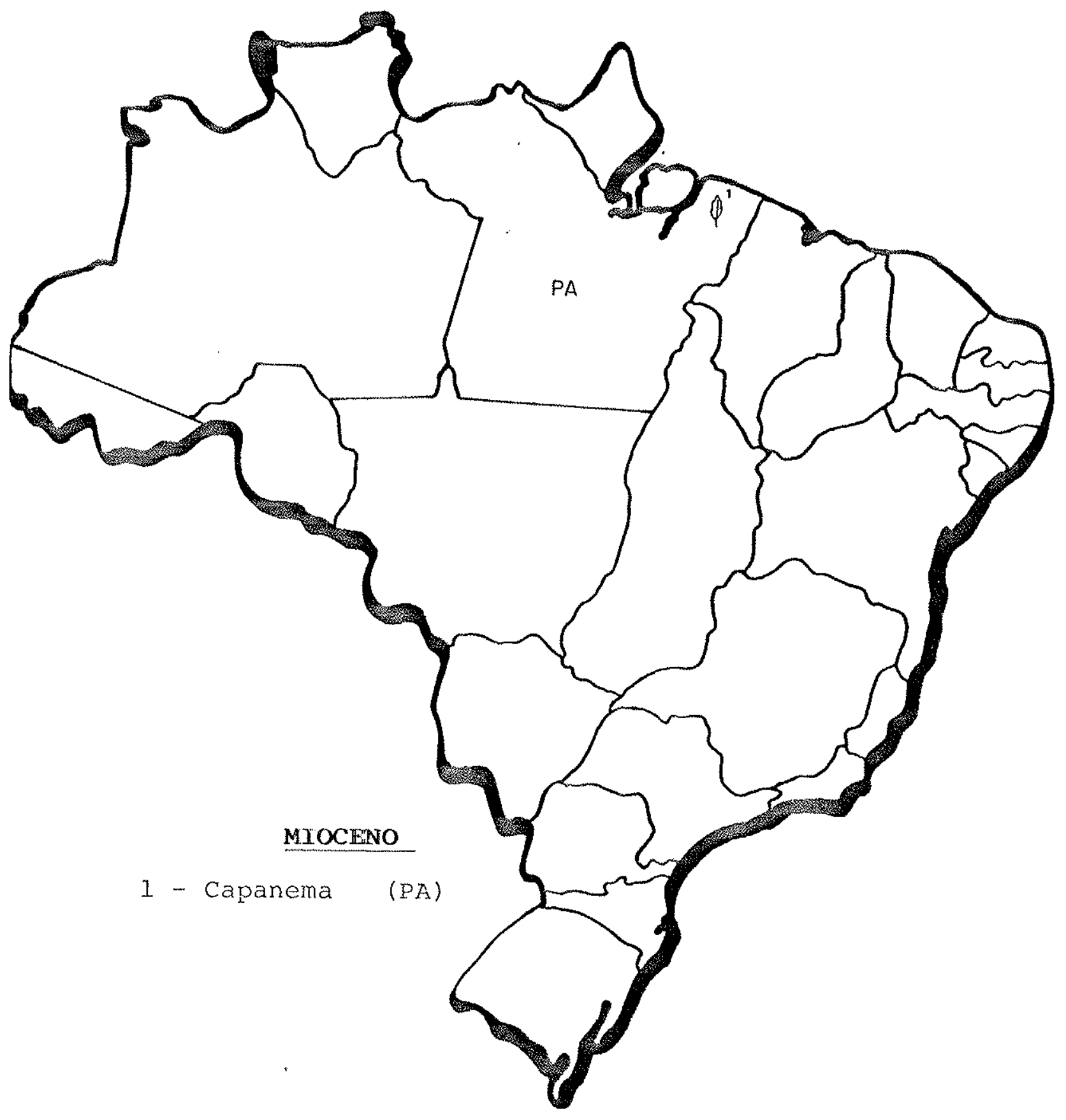




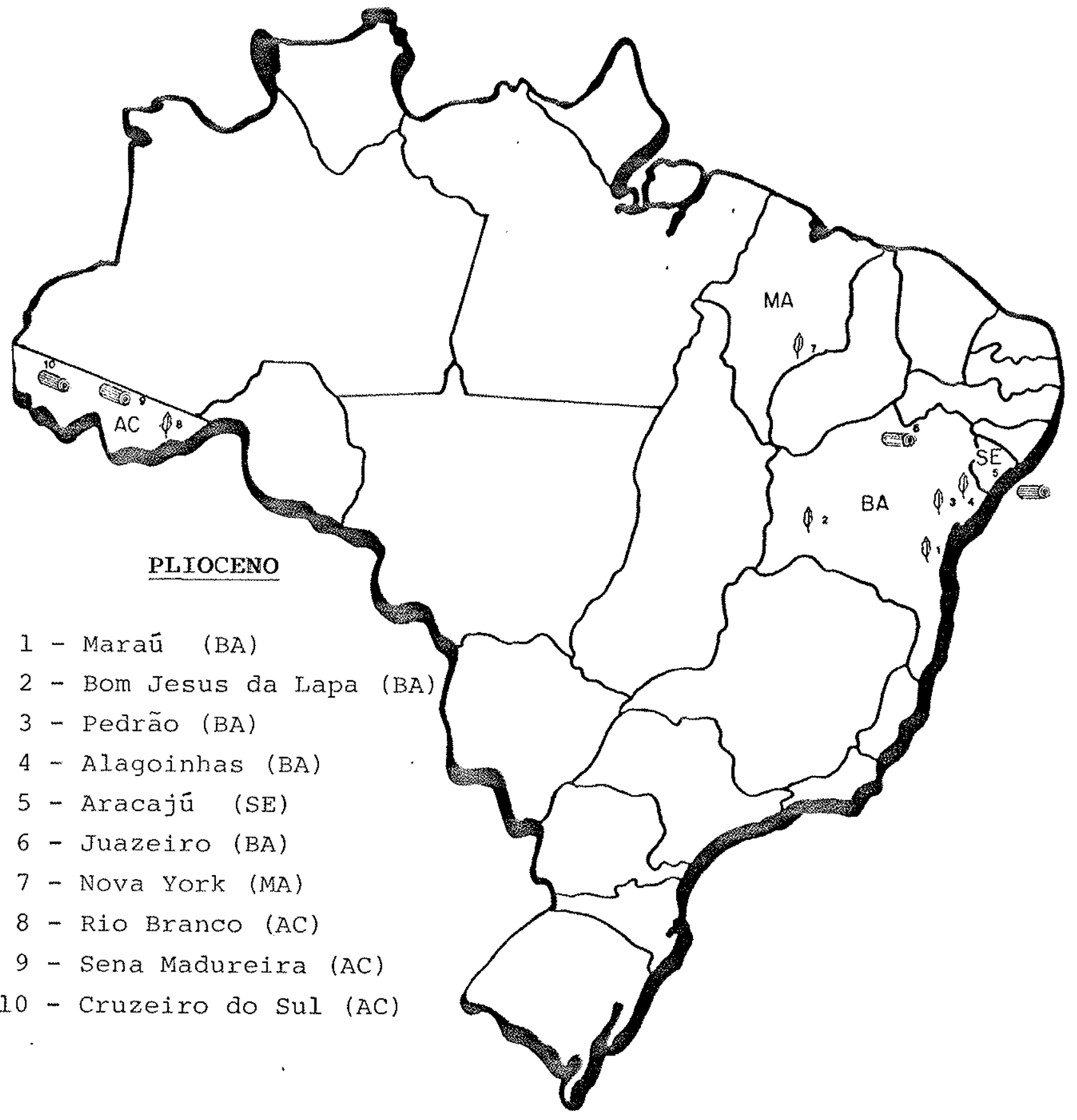




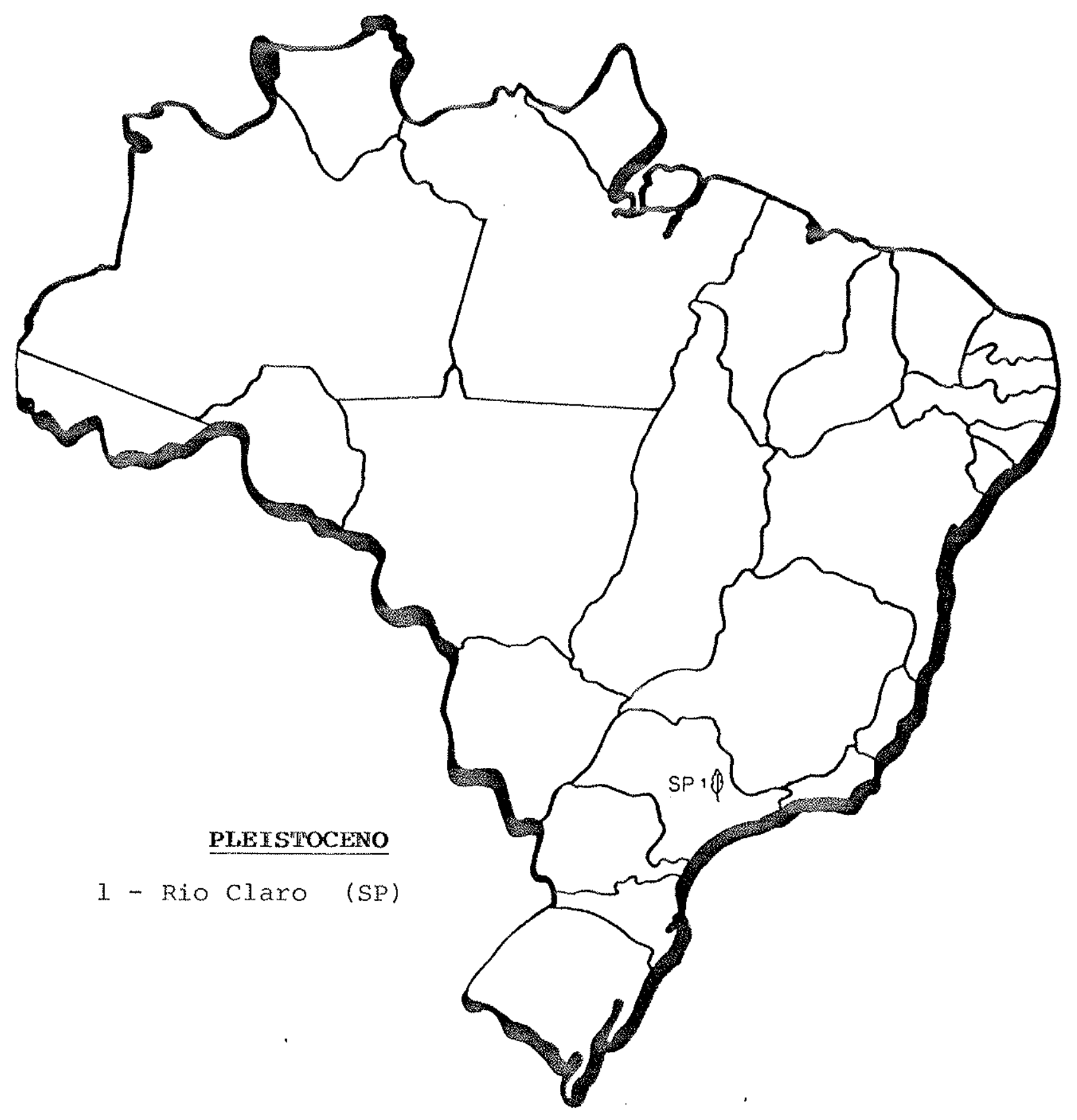




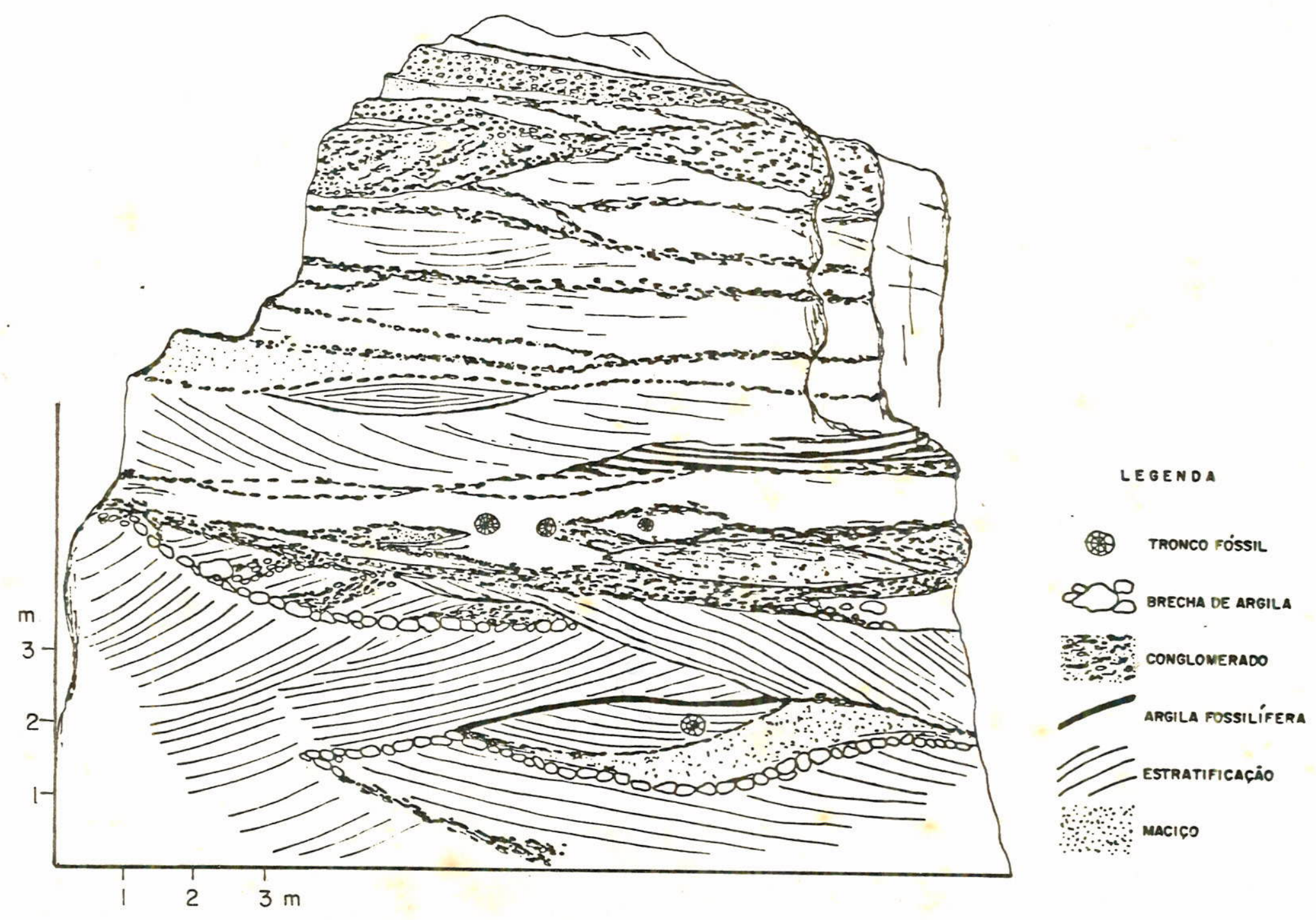

Seção-tipo da Formação Itaquaquecetuba, entrada do porto de areia no I da Itaquareia, margem direita do Rio Tietê, Itaquaquecetuba, SP (RICCOMINI, 1989). 